Ho Mo 

NORTHEASTERN UNIVERSITY LIBRARY 



\title{
BULLETIN
}

OF THE

\section{NATIONAL RESEARCH COUNCIL}

\author{
PROCEEDINGS \\ OF THE \\ THIRD ANNUAL MEETING \\ OF THE
}

ADVISORY BOARD ON HIGHWAY RESEARCH, DIVISION

OF ENGINEERING, NATIONAL RESEARCH COUNCIL

Held at Washington, D. C.

November 8-9, 1923

\begin{abstract}
EDITED BY
William Kendrick Hatw, Director, Advisory Board AND

E. R. OlbRich, Assistant to the Director
\end{abstract}

Published by the National Research Council

OF

The National Academy of Sciences

Washington, D. C. 


\section{Announcement Concerning Publications}

of the

\section{National Research Council}

The Proceedings of the National Academy of Sciences

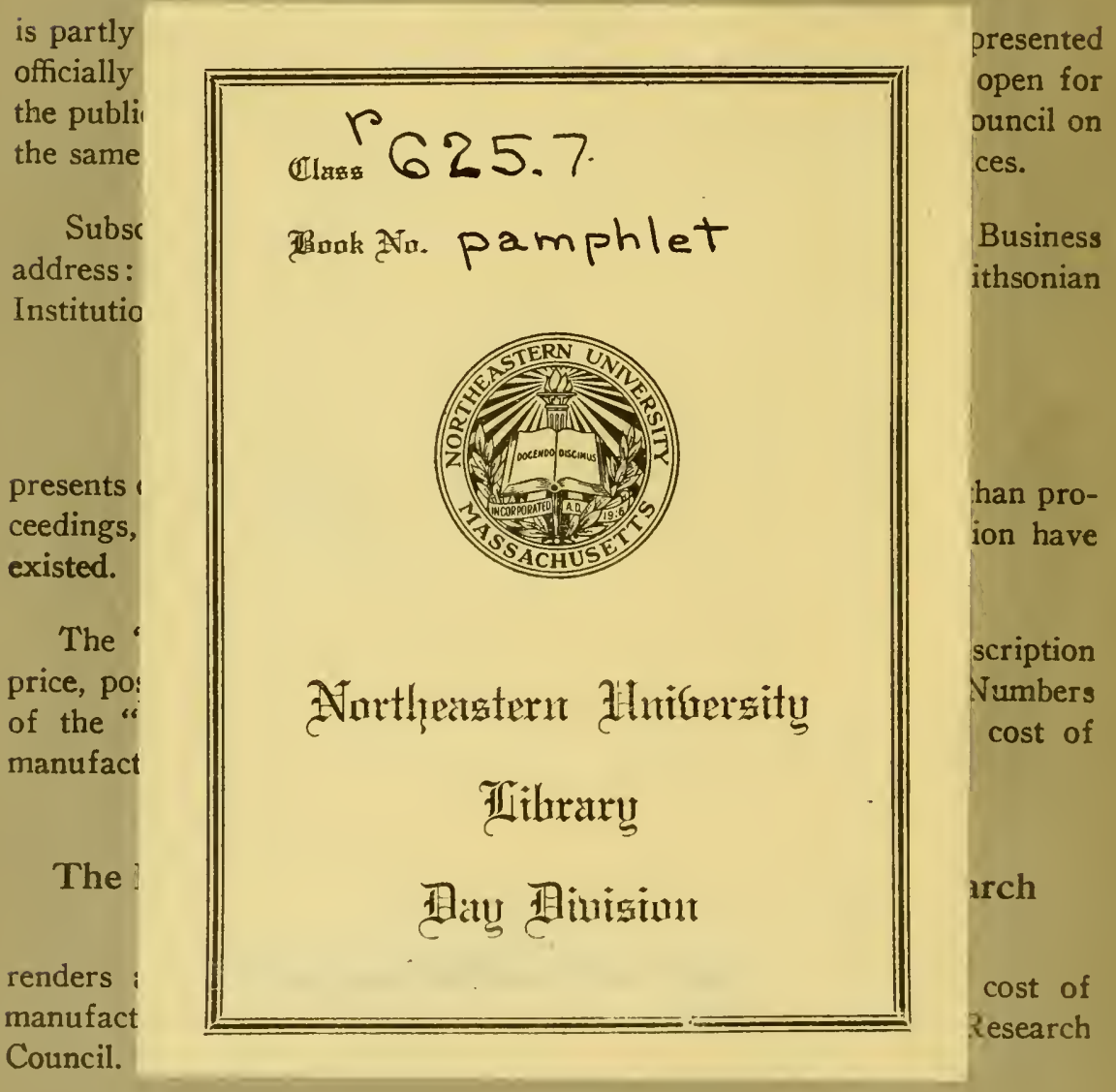

Orders for the "Bulletin" or the "Reprints and Circulars" of the National Research Council, accompanied by remittance. should be addressed: Publication Office, National Research Council, I70 I Massachusetts Avenue, Washington, D. C. 


\section{BULLETIN}

OF THE

\section{NATIONAL RESEARCH COUNCIL}

Vol. 8 Part 1

MARCH, 1924

Number 43

PROCEEDINGS' OF 'THE THIRD INNUAL MEETING OF

THE ADVISORY BOARD ON HIGHWAY RESEARCH, DIVISION OF ENGINEERING, NATIONAL

RESEARCH COUNCIL

Edited by Willian Kendrick Hatт, Director, Advisory Board and

E. R. Otbrich, Assistant to the Director

\section{TABIS OF CONTENTS}

I'AsT' I

Page

Summary of development of Adrisory Boald . . . . . . . . . . 3

By-laws of Advisory lioard . . . . . . . . . . . . . . . :

Constituent members and representatives . . . . . . . . . . . 7

Research committees . . . . . . . . . . . . . . . . . .

Registration of attendance at meeting . . . . . . . . . . . . 13

I'Al'T' II

Program of the Third Immual Meeting . . . . . . . . . . . . 17

Interim actions of the Executive Committe . . . . . . . . . . 18

Nomination of officers . . . . . . . . . . . . . . . . . 19

Report of director . . . . . . . . . . . . . . . . . . . . 19

Report of Committee No. 1, Economic Theory of Highway Improvement 31

Report of Committee No. 2, Structural Design of Roads . . . . . 6t;

Report of Committee No. :3, Character and Use of Road Materials . . 97

Objectives in Highway liesealch, Thomas H. MacDonald . . . . . 105

Highway Research Work of American Assoriation of Land Grant Colleges, Anson Marston . . . . . . . . . . . . . 109

Report of Committee No. fi. Highway Finance . . . . . . . . . 111

Research Program of North Carolina State Highway Commission,

Charles M. Cpham . . . . . . . . . . . . . . . . . . 124

Report of Committee No. 4, Highway Traflic Analysis . . . . . . 131

Report of Committee No. T, Maintenance . . . . . . . . . . . . . 148

Statements of representatives of constituent organizations . . . . 155

Election of officers . . . . . . . . . . . . . . . . . . . 162 


$$
\begin{aligned}
& 4 \\
& 11 \\
& \text { Nog } \\
& 7 x+3
\end{aligned}
$$

$$
21325066
$$




\section{PART I}

\section{SUMMARY OF DEVELOPMENT OF ADVISORY BOARD}

\section{Chronological Statement}

The National Research Council was established in the spring of 1916, when President Wilson requested the National Academy of Sciences to organize the scientific and engineering forces of the United States for the purpose of defense. The Engineering Committee of the National Research Council did effective work during the war.

On May 18, 1918, by executive order, President Wilson perpetuated the National Research Council and attached it to the National Academy of Sciences, which had been incorporated by congressional charter, approved by President Lincoln, March 3, 1863.

The Division of Engineering of the National Research Council occupies offices in the Engineering Societies Building, New York. The Engineering Foundation, which is closely affiliated with the Engineering Division, provides an office for the Division adjoining its own, and contributes a portion of the funds needed for the administrative expenses of the Division.

Advisory Board on Highway Research:

On October 26, 1920, the Chairman of the Engineering Division addressed a communication to the governing boards of certain national organizations, Federal and State departments, and educational institutions, stating the need for highway research, outlining projected committee organization, and inviting representatives to a conference for the purpose of completing the organization.

At that meeting, held November 11, 1920, an Advisory Board on Highway Research was organized and by-laws adopted.

\section{BY-LA IIS OF ADVISORY BOARD}

As Adopted November 11, 1920, and Amended January 16, 1922; August 4 , and March 23,1923

(1) Name: Advisory Board on Highway Research of National Research Council.

(2) Purposes:

(a) To assist in outlining a comprehensive national program of highway research and coordinating activities thereunder. 
(b) T'o organize committees for specitic problems.

(c) To rleal with ways and means.

(d) To act in a general advisory capucity.

(:) Membersteip: Those organizations of national inportance interested in design, construction. exonomics, maintenance and finaneing of highways, in materials and equipment therefor, and in rehicles used on highways; goverumental departments and bureaus of similar interests. and the higher educational institutions, each acting though one duly appointed representative, with authority to name an alternate, serving until appointment of his successor. New organization members shatl be elected ly letter ballot of the Board upon recommendation by Executive Committee. Qualification shall be completed within three months by appointment of a representative.

(4) Officers: Chairman, Vice-Chairman and Director, who shall perform the usual fimetions. Chaimuan and Vice-Chairman elected annually by the Board in meeting or by letter ballot; to serve one year from Jamuary 1 following clection, or until successors qualify. In case of letter ballot, nominations shall be made by Executive Committee or by Division of Engineering.

(5) Director: Shall be engaged by Executive Committee and serve at the will of that committee; slatl be paid a salary fixed by that committee; shall be the executive officer of the Board; shall be a professional engineer; shall devote his whole time to the ruties of his office; shall account to the Executive Committee for all moneys received and disbursed.

(6) Administrative Committees:

(a) Exccutive: Consisting of the Chaiman, the Vice-Chairman and five additional members ehosen by the Board, at least two of whom shall also be nembers of the Division of Engineering. Should a vacancy exist in the Executive Committee, it shall be filled by a rote of the lemaining nembers.

(b) Hays and Means: Three nembers inpointed by the Chairman.

1)uties: Thuse indicated by the titles and such others as may be assigned by the Board. Executive Committee shall also aid ('hairman and Director in carrying out instructions of the Board and in formulating projects to be 
presented to the Board; shall act for the Board in routine matters, and shall control publicity.

(7) Research Committees: Shall be created by the Board, as deemed necessary, with the approval of the Division of Engineering. Member's shall be appointed by the Chairman of the Board with approval of the Executive Committee, and need not be limited to members of the Board. The term of services of members of Research Committees shall be limited to one year, but they are eligible to reappointment. The following are established upon adoption of these By-Laws:

(a) Bibliography. ${ }^{1}$

1. Economic Theory of Highway Improvement.

2. Structural Design of Roads.

: Character and Use of Road Materials.

4. IIighway Traffic Analysis.

5. Highway Bridges. ${ }^{1}$

6. Highway Finance.

7. Maintenance of Highways.

(8) Meetings: Annual meeting, second Thursday of November, at a place to be designated by the Chairman. Other meetings at eall of Executive Committee, on twenty days' notice.

(9) Amendments: May be made by a majority of the Board, on thirty days' notice, by letter ballot.

The purposes of the Board are, briefly : T'o prepare a comprehensive national program for highway research; to assist existing organizations in coordinating their activities and to collect and distribute information of completed and current research.

On July 11, 1921, the Executive Committee met and engaged a Director and authorized the Chairman and Vice-Chairman to prepare cooperative agreements with the Bureau of Public Roads, the State Highway Departments, and other organizations adapted to instituting and coordinating a national program for highway research. It was voted that the National Research Council be requested to act as financial agent for the Advisory Board, and that the Vice-Chairman of the Board be authorized to approve bills and sign requisitions for payment of expenses.

The following resolutions on committees were adopted:

Toted,--that no person be appointed to a research committee under the auspices of the Advisory Board on Highway Research who

\footnotetext{
${ }^{1}$ Committee not organized.
} 
cannot derote sufficient time to the committee's work and that the personnel of each committee be subject to approval by the Executive Committee.

It is the consensus of opinion that, whenever desirable, the personnel of a committee shall include suitable representatives of interested industries.

On December 2, 1921, a report of this conference was sent to all participating individuals and organizations.

Later activities of the Advisory Bourd on Highway Research are summarized in the published proceedings of the annual meetings. 


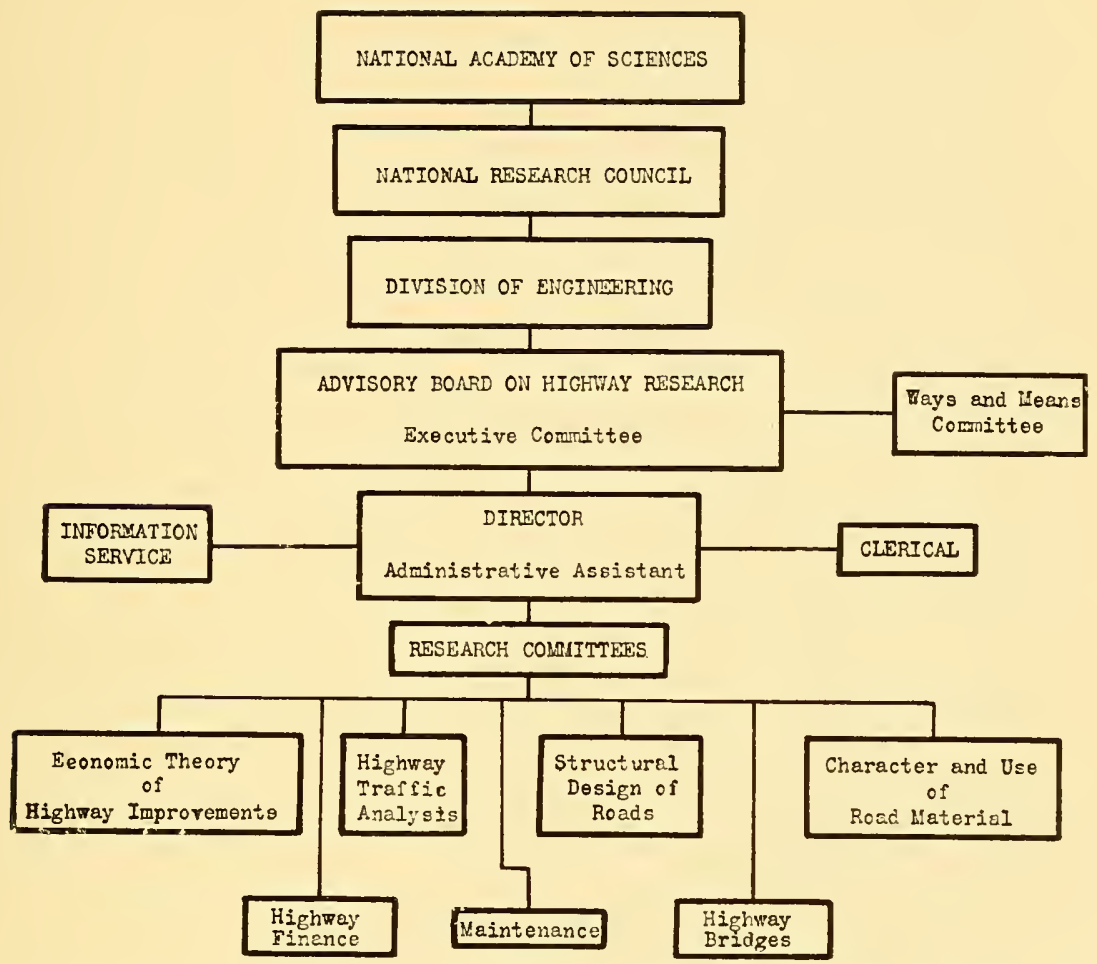

Officers axd Memiers of Executive Committee for 1924

Chairman: 1. N. Johnson, Dean, College of Engineering, Unirersity of Maryland.

Vice-Chairman: Alfred D. Flinn, Nember, American Society of

Civil Engineers; Director, Engineering Foundation; formerly Deputy Chief Engineer, Catskill Water Supply for New York City.

Other Members of Executive Committee:

Thomas H. MacDonald, Chief of Bureau of Public Roads, U. S. Department of Agrieulture.

'T. R. Agg, Division of Engineering, N. R. C., Iowa State College.

H. C. Dickinson, U. S. Bureau of Standards.

A. J. Brosseau, President. Maek Trueks, Ine.

C. M. Upham, State Highway Engineer, North Carolina. 
Menher Organizations and Timeir Replesentatives

American Association of State Highway Officials:

Representative, Clifford Older

American Concrete Institute:

Representative, C. R. Egc

Alternate, E. J. Moore

American Institute of Consulting Engineers:

Representative, Philip $\mathbb{W}$. Henry

Alternate, F. A. Molitor

American Society of Civil Engineers:

Representative, liobert A. Cummings

Alternate, J. S. Iangthorn

American Socicty of Mechanical Engincers:

Representative, H. de B. Parsons

Alternate, Diniel k. Moran

American Society for Municipal Inprovenents:

Representative, Nelson I'. Iewis

Alternate, Manley ()sgood

American Society for 'T'sting Materials:

Representative. Prevost Ilublard

Alternate. A. N. Johnson

Associated General Contrators of Anerica:

Riepresentative, H. II. Milson

Alternate, George M. Fandy

Association of American siate Gicologists:

Representative, 11. A. Buchler

Alternate, E. B. Mathews

Bureau of Public lioats, U. S. Departurent of Agriculture:

Representative, Thos. Il. Machonald

Alternate, A. 'T. Goldheck

Bureau of Standards. U. S. Departunent of Commeree:

Representative. II. A. Slater

Alternate, H. L. Whittemore

Corps of Enginecrs, U. S. Army:

Representative, Col. John C. Oakes

Eno Foundation for 1 lighway Traftic Regulation:

Represontative. Willian P’. Eno

Engincering Foundation:

Representative, Alf reed D). Flimn

National Automolyle Chamber of Commeree:

lieprescutative. 1. . . Brosseau 
National Highway Traffic Association:

Representative, Arthur H. Blanchard

Alternate, George H. Pride

Rubber Association of America:

Representative, H. S. Firestone

Alternate, A. I. Viles

Society of Automotive Engineers:

Representative, Darid Beecroft

Second Representative, H. W. Alden

Alternate, Henry M. Crane

Western Society of Engineers:

Representative, A. N. Talbot

Alternate, Linn White

American Road Builders Association:

Representative, H. E. Breed

Alternate, H. G. Shirley

National Safety Council:

Representative, R. I. Kelker, .Jr.

Alternate, Fred M. Rosseland

Association of Land Grant College: :

Representative. Mnson Marston

\section{RESHARCH COMMITTEES}

(1) Commetee ox Ecoxonic 'Theor of Highway ThproveMENT

Problem: To determine all of the elements of cost of highway improvement.

The following will suggest the type of research involved:

A. Effect of grades, alignment, rise and fall, weather and speed and methods of operation on cost of transport.

B. Determination of all of the elements entering into the resistance to translation of vehicles (tractive resistance) and magnitude of each element.

C. Determination of the elements of cost of rehicle transportation classed as capital costs, and operating costs exclusive of those included in $A$ and $B$.

D. To determine the relation between traffic and capital and maintenance costs of roads.

\section{Membership:}

Chairman, T. R. Agg, Iowa State College

L. E. Conrad, Kansas State Agricultural College 
II. C. Dickinson, Sueiety of Automotive Engineers H. S. Fairbank, U. S. Bureau of Public Roads

A. B. Fletcher, Boston, Mass.

H. J. Hughes, Harvard University

Mark L. Ireland, Quartermaster Corps, U. S. Army E. W. James. U. S. Burean of Public Roads

H. J. Kuelling, Wiseonsin State Highway Commission

E. H. Lockwood, Yale Lniversity

Charles M. Manly, New York City

Tom Snyder, Indianapolis, Ind.

(2) Committee on Stretctial Design of Rohdos

Problem: 'To establish all of the data required for the rational design of a road surface.

The following will suggest the ype of researeh involved:

A. To determine all facts relative to the behavior of the soil upon which roads are constructed, when under load from the road structure.

B. To determine the relation between traffic loads and stress in road surfaces. and to establish the laws that control.

C. To determine the effeets of the elements on road structures.

D. To determine the structural strength of all types of road surfaces.

E. Relation of the vehicle to the road.

Membership:

Chairman, A. T. Goldbeck, U. S. Bureau of Public Roads

C. A. Hogentogler, U. S. Bureau of Public Roads, Seeretary

Lloyd Aldrich, San Franciseo, California

H. C. Berry, University of l'ennsylvania

H. E. Breed, New York University

F. H. Eno, Ohio State University

E. IV. James, U. S. Bureau of Public Roads

Clifford Older, Division of Highways, State of Illinois

11. G. Shirley, Virginia State Highway Commission

F. B. Smith, U. S. Bureau of Public Roards

C. M. Strahan, Tniversity of Georgia 
E. IV. Templin, Akron, Ohio

C. M. Upham, North Carolina State Highway Commission

H. M. Westergaard, University of Illinois

(3) Committee ox Character axd Use of Road Materials

Problem: To determine the most effective combinations of materials to give desired strength, and to investigate possible new combinations of materials.

The following will suggest the type of research involved:

A. To establish the most effective combinations of materials now in nse, with particular reference to the exigencies of the field control.

B. To promote research looking to the establishment of new combinations of materials, or of the new materials suitable for road surfacing.

Membership:

Chairman, H. S. Mattimore, Pennsylvania State Highway Department

B. A. Anderton, U. S. Burean of Public Roads

E. W. Crum, Iowa State Highway Commission

F. C. Lang, University of Minnesota

C. S. Reeve, New York City

H. H. Seofield, Cornell University

M. O. Withey, University of Wisconsin

(4) Commttee ox Highway Traffic Axalysis

Problem: To establish an adequate method of studying highway traffic and to show how traffic records should be interpreted.

The following will suggest the type of research involved:

A. To study relation of community development of the origin and destination of traffic, and to devise means for estimating potential traffic.

B. Proper method for studying and recording volume of traffic and for interpreting traffic records.

C. To devise units of measure to apply to traffic and to define those units.

D. To study the relation of highway betterment to traffic increases. 
Membership:

Chairman, Geo. E. Hamlin, Connecticut State Highway Commission

T. R. Agg, Iowa State College

A. H. Blanchard, University of Michigan

N. W. Dougherty, Unirersity of Tennessee

A. N. Johnson, University of Maryland

Nelson P. Lewis, New York City

J. H. Mullen, Minnesota State Highway Department

(5) Committee on Highway Bendes

Problem: To establish all of the data required for the design of highway bridges.

The following will indicate the type of research required:

A. Determination of loads for which bridges should be designed.

B. Study of impact on highway bridges.

C. Determination of the proper requirements for standards of design as regards allowable stresses, width and requirements of foundations.

(Committee not yet organized.)

(6) Comalttee on IIjginay Finance

Problem: 'To determine the equitable hasis for financing highway improvements.

The following will indicate the type of rescatreh involved:

A. Definition of an equitable basis for highway tinaneing.

B. Study of possible methods of financing improvements in the rarious political units.

C. Administrative methods required to insure equitable financing.

Nembership:

Chairman, J. G. Mckay, U. S. Burean of Public Roads (Committee not yet organized.)

(7) Committee on Minntenance

Problem: 'To determine the relation between traftic and maintenance costs of roads, to investigate methods of maintenance and organization of maintenance forces. 
The following will suggest the type of rescareh involved:

A. Establishment of aeeounting methods that will give aecurate data on cost of maintenance.

B. Methods of eorrelating maintenanee costs and volume of traffic.

C. Relation of maintenanee costs to methods of maintenance.

Membership:

Chairman, W. H. Root, Iowa State Highway Department

H. K. Bishop, U. S. Bureau of Public Roads

G. C. Dillman, Miehigan State Highway Department

J. T. Donaghey, Wisconsin State Highway Commission

A. H. Hinkle, Indiana State Highway Commission

II. G. Hotchkiss, Jr., New York State Highway Commission

Wm. Arthur MeLean, Department of Publie Highways, Ontario, Canada

T. E. Stanton, California State Highway Commission, Saeramento, California

W. A. Van Duzer, Pennsyliania State Highway Department

\section{REGISTRATION OF ATTENDANCE A'T MEETING OF NOVEMBER 8 AND 9, 192:;}

Agg. T. R.......... lowa State College

Alden, H. W......... Society of Automotive Engineers

Almquist, E. G. . . . . . . U. S. Bureau of Publie Roads

Anderton, B. A . . . . . . U. S. Bureau of Publie Roads

Anmun, von S...... U.S. Bureau of Standards

Bachman, B. B....... A utocar Company, Ardmore, Pa.

Berry, H. C......... University of Pennsylvania

Bibbins, J. R........ Consulting Engineer, Washington, D. C.

Bishop, H. E. ........ U. S. Bureau of Public Roads

Blair, Will B....... National Paving Brick Manufacturers Association

Boyd, J. R.......... U. S. Bureau of Publie Roads

Braume, G. N....... University of North Carolina

Breed, H. E.......... New York University 
Casman, M. L........ Motor Transport Engineer, Pennsylvania Department of Highways

Christie, Ward P....... Research Manager, Association General Contractors

Crandell, John S...... The Barrett Company

Crane, Henry M....... Society of Automotive Engineers

Curtiss, C. D . ........ U. S. Burcau of Public Roards

Dalton, James......... Editor, Automotive Industries

Dickinson, H. C....... U. S. Bureau of Standards

Duchastel, J. A........ Canadian Good Roads Association

Duff, Edward E., Jr..... National Paring Brick Manufacturers Association

Ege, C. R.......... American Concrete Insitute

Eldridge, M. O....... American Automobile Association

Elveljen, O. M......... U. S. Bureatu of Public Roads

Eno, F. H.......... Ohio State University

Fairbank, II. S........ U. S. Bureau of Public Roads

Fenner, D. C......... Motor Vehicle Corporation Commission

Fletcher, A. B........ U. S. Bureau of Public Roads

Flinn, Alfred D....... Engineering Foundation, New York

Forrest, C. H........ The Barber Asphalt Company

French, Owen B....... George Washington University

Goldbeck, A. T . . . . . . . U. S. Bureau of Public Roads

Greer, W. C.......... Goodrich Rubber Company, Akron, Ohio

Hamlin, George E..... Connecticut State Highway Department

Hatt, W. K......... Director, Advisory Board on Highway

Researeh, National Researeh Council

Hill, Charles S....... Engineering News-Reeord

Hoag, G. S. . ......... Field Sceretary, Lincoln Highway Association

Hogentogler, C. A...... U. S. Bureau of Public Roads

Holt, W. L. . . . . . . . U. S. Bureau of Standards

Hubbard, Prérost...... American Society for Testing Materials

Hughes, H. J........ Dean, Harvard Engineering School

Jackson, F. H.......... U. S. Burean of P'ublic Roads

James, E. W. . . . . . . . U. S. Burean of Public Roads

James, W. S........ U. S. Bureau of Standards

John, W. C.......... Secretary, Highway Education Board

Johnson, A. N . ....... University of Maryland

Johnson, Pyke........ National Antomobile Chamber of Commerce 
Kearney, W. G........ Goodrich Rubber Company, Cleveland, Ohio

Ketchum, M. S....... University of Illinois

Lapman, J. R........ George Washington University

Lay, W. E........... University of Miehigan

Lemon, B. J.......... U. S. Tire Company, New York

Litchfield, P. W....... Goodyear Rubber Company, Akron, Ohio

Lord, W. E. . . . . . . . U. S. Bureau of Public Roads

Love, H. J.......... National Slag Association

MeComas, W. E., Jr.... Portland Cement Association, Baltimore, Md.

MeDaniel, A. B....... General Staff, War Department

MacDonald, T. H. ...... U. S. Bureau of Public Roads

MeKay, J. G. ......... U. S. Bureau of Public Roads

MeNown, W. C....... University of Kansas, Lawrence, Kans.

Manly, Chas. M........ Society of Automotive Engineers

Markham, W. C....... Secretary, American State Highway Officials

Mitinger, H. C........ Gettysburg, Pennsylvania

Mullis, Ira B........ U. S. Bureau of Public Roads

Olbrich, E. R......... Assistant Director, Advisory Board on Highway Researeh

Older, Clifford......... Division of Highways, State of Illinois

Page, Frank......... North Carolina State Highway Commission

Reed, Edward E....... Assistant State Highway Engineer, Trenton, N. J.

Reeve, C. S......... The Barrett Company, New York

Reid, J. W......... U. S. Bureau of Publie Roads

Ricker, George A..... Portland Cement Association, D. C.

Robinson, V. D. L..... Ameriean Motorist

Root, W. H........... Iowa State Highway Department

Selden, H. W........ Soeiety of Automotive Engineers

Shirley, H. G....... Virginia State Highway Commission

Smith, E. B......... U. S. Bureau of Public Roads

Sparrow, Stanwood W... U. S. Bureau of Standards

Spraragen, IV ........ Engineering Division, National Research Council

Sprawls, G. M........ Goodyear Rubber Company, Akron, Ohio 
Sproull, J. C......... Goodrich liubber Company, Akron, Ohio

Strahan, C. M......... Athens, Georgia

Teller, I. W......... U. S. Burean of Public Roads

Tilden. C. . .......... Yale University and Eno Foundation

Tohin, J. J......... Granite Paving Block Manufacturing Association, Buston, Mass.

Upham, C. M......... North Carolina State Highway Commission

Warner, J. A. C....... Society of Antomotive Engineers

Westergaard, H. M ..... Eniversity of Tllinois

Woods, S. H.......... Mack Trucks, Ine. 


\section{PROGRAM OF T'HIRD ANNUAL MEETING}

First Session, Thursday, November 8,10 a. m.

(1) Approval or correction of minutes of November 23, 1922

Announcement of vote on changes in By-Laws

(2) Approval of interim actions of the Executive Committee

(3) Appointment of Committee on Nomination of Officers

(4) Report of Director

(5) Report of Committee No. 1, Economic Theory of Highway Improvement-Chairman, T. R. Agg

"Research on Rubber Tires," W. L. Holt, U. S. Bureau of Standards

(6) Report of Committee No. 2, Structural Design of RoadsChairman, A. T. Goldbeck

(7) Report of Committee No. 3, Character and Use of Road Naterials-Chairman, H. S. Mattimore

$$
\text { Afternoon, 2:30 p. m. }
$$

$A$ visit of inspection was made to the new building of the National Research Council, located near the Lincoln Memorial, and to the highway research projects of the Burean of Public Roads at Arlington, Va.

$$
\text { Second Session \%:30 p. m. }
$$

(8) Address: "Objectives in Highway Research"-Thomas H. MacDonald, Chief, U. S. Bureau of Public Roads

(9) "Highway Research Wrork of American Association of Land Grant Colleges"-Dean Anson Marston, Iowa State College

(10) Report of Committee No. 6, Highway Finance-Chairman, J. G. McKay

(11) "Research Program of North Carolina State Highway Commission"-Charles M. Upham, State Highway Engineer of North Carolina

Third Session, Friday, November 9, 9:30 a. m.

(12) Report of Committee No. 4, Highway Traffic AnalysisChairman, Geo. E. Hamlin

"Analysis of Notor Transport in New England," Dr. J. G. MeKay 
(13) Report of Committee No. 7 , Maintenance-Chaiman, IV. II. Rioot

(14) Statements of representatives of constituent organizations

(15) Report of Committee on Wars and Means

(16) Election of officers

The presiding oflicer, I) An A. N. Johnson, of Naryland University, Chairman of the Advisory Board, called the meeting to order at 10 a. $m$.

The minutes of the second annual meeting. Norember 28, 1922, were approved.

An announcement was made of the amendments to the By-Laws. as stated in Section 5 of the Director's report.

\section{INTERIM ACTIONS OF THE EXECUTIVE COMIIT'TEE}

Chairman Johnson: There are some interin actions of the Exeeutire Committee which the Director will report.

The Director: 'The actions that should be reported are:

(1) The resignation of Director Hatt was accepted, to take effect on the date mutually agreed upon by the Director and the Chairman of the Executive Committee.

(2) Amendments to Sections $6 a$ and 7 of the By-Laws, as stated in Section 5 of the Director's report, were authorized for submission to letter ballot.

(3) Provision was made for the employment of a full-time technical assistant. Upon the authorization of the Executive Committee. Chairman Johnson and Director Hatt recommended to the Excentive Committee Mr. E. R. Olbrich, Construction Enginecr. North Carolina Highway Commission, to be appointed as Technieal Assistant to the Director. The appointment was made ly the Executive Committee.

(4) The Executive Committee on March 10, 192:;, andopted the following resolution :

"It is the sense of the Executive Conmittee of the Advisory board that interest in the work of the Board would be more widcly spread if the terms of scrvice of the official representatives of constituent organizations of the Board were limited to three years."

Dr. Hatt read a letter from Morris L. Cooke. Direetor of the Giant Power Survey of the Commonwealth of Pennsylvania, requesting that the Board undertake an inquiry as to prisible conperation between the state highway commissions and the power companies for mutual benefit in erecting transmission lines, on a joint right of way. 
to carry electric current to rural communities. Mr. Cooke's letter was referred to the Executive Committee for such action as they should deem advisable.

\section{NOMINATION OF OFFICERS}

The chairman appointed the following Committee on Nomination, consisting of Professor Tilden, Mr. Goldbeck and Mr. Root.

\section{REPORT OF THE DIRECTOR, ADVISORY BOARD ON HIGHWAY RESEARCI}

\section{I'ROGRESS SINCE NOYEMBER, 1920}

The third annual meeting of the Advisory Board on Highway Research offers occasion for a retrospect of the progress of the Advisory Board since the inaugural meeting in New York, November 11, 1920. At that time Dean Anson Marston, of Iowa State College, then Chairman of the Advisory Board, spoke in part as follows:

“. . . It (highway research) must be of a highly scientific character and devoted very largely to consideration of fundamental engineering science because the fundamental theory of highway engineering has not been developed."

". . . We have run ahead of our theory. There is no engineer at the present time who can build either a concrete, bituminous or brick road with absolute certainty that it will carry the traffic of motor trucks weighing a given number of tons, traveling at specified speed, with certainty that it will not be broken by traffic instead of gradually worn out. There is no way to tell stresses in various parts of a structure which we are to build."

"This general principle applies not only to experimental work, but to economic research. Who has adequate data for determining how the roads of a state should be classified into primary, secondary and third-class roads, or who can tell us the proper relation of transportation over country highways to railway and waterway transportation, considered from the standpoint of the interests of the entire country? The best administration of this great program requires research."

". . . We have to think of road surfaces which vary from mud of some localities, dry sands of the desert, to solid rock of the mountain regions; climates which vary from tropical to roads above the snow-line in the mountains. Adequate highway research will require an accumulation of an immense mass of data to solve the problem adequately. . . . Chairmen of research committees should be in every instance scientific research men actively engaged in re- 
search personally. I don't think we ean earry this on with men who will only conduct the administrative operations. They should be men of the highest scientific attainments and able to analyze results from a theoretical point of view as well as to conduct the tests. They should devote at least a greater part of their time to the work. It is not a case where two or three can be called together once or twice a year and do nothing in the meantime. The greatest obstacle we have had is the fact that the chairmen in each case have been men whose regular duties require the greater part of their time. The ideal plan would be to have each man employed on a salary, who would devote full time to the work of the committees. Those should also be men with some administrative ability, men of judgment and so on."

". . . Each committee should have a salaried chairman. If we can't get that, we should get the right to use as much of his time as practicable. Te should have sufficient money to pay mileage and similar expenses of members of the committees."

During the three years that have elapsed since Dean Marston's address, much progress has been made in quickening the will to research, in mobilizing the energies of research agencies and in assembling the data necessary for judgment upon questions of highway planning, construction and operation.

It may be said with a large degree of confidence that at present a well-trained and experienced highway engineer, in possession of available data, can select a type of highway suitable to the conditions of climate and traffic of a given situation, can select the materials and design the section with a reasonable certainty that it will withstand the specified conditions of service.

It is true that the communication of these data to engineers in general has not kept pace with the accumulation of the data, nor has a working organization for the process of analyzing the data and translating the discovered principles for the use of engineers been adequately provided. The $\Lambda$ dvisory Board has pulblished bulletins of information on existing research projects, on apparatus for research, and the Director has written many occasional papers. Its research committees have summarized progress. Much remains to be done, however, in unlocking the stored-up data, especially those in the files of the state highway commissions, which are now such active agencies in highway research.

It is still true that the conditions of future service of our highways can not be closely specified. In the majority of cases the classification of highways is based on general impressions. However, such traffic surveys as those under way in New England, Pennsylvania, Iowa, California, Tennessec, etc., permit a classification based on 
actual measurements and an intelligent allocation of construction and maintenance funds. Furthermore, commodity movements, such as determined in the Connecticut Survey, go a long way in fixing the boundaries of the field of economic highway transport.

While much remains to be done in coordinating the activities of the various research agencies, a human problem in many cases, the highway engineer and the automotive engineer lave come to a better understanding of their mutual relations in the field of research and to a combined effort to determine the mechanical relations of the road and vehicle.

Questions of finances and taxation have been actively debated during the past year. Gradually an understanding of the elements of the subject and of their application to specific situations is reaching the mind of the public.

The paper entitled "The Human Factor in Highway Regulation and Safety," by Dr. Raymond Dodge, presented to the second annual meeting of the Advisory Board, called attention to the mental problems in traffic control, including tests for driving ability. The alarming number of fatalities attending highway traffic indicate a need for research, not only in respect to the field dealt with by Dr. Dodge, but in respect to vehicle design, road location, and signals. Matters of this kind tend to become legislated and standardized prematurely without a scientific basis of research.

\section{RESEARCH COMMITTEES OF THE ADVISORY BOARD}

Dean Marston's reasonable specifications for the chairmen of research eommittees remain unfulfilled in one respect. The present chairmen of our research committees are distinguished leaders in their respective fields and actively interested in research. The Advisory Board is very grateful for the amount of energy and excellent service that our chairmen have giren to the committee work on the Advisory Board. But each is a busy man, with heary responsibilities to discharge and duties to perform in the organization to which he owes his first allegiance. Some way should be found to free their energies to a greater extent for the work of the Board.

\section{RESEARCH INFORMATION SERYICE}

An important service, one which the Advisory Board might well accomplish on the basis of its present position and through the contacts already made, has not been rendered, namely, the preparation of research information in form for busy executives and engineers. Such a service would require a small staff of specialists who would garnor up the crops of research data in the several fields and prepare 
them for use. The channel of publication might be a monthly magazine or a more freguent leaflet service. The complete publication of ambitious rescarch projects is now well provided for in the magazine of the Bureau of P'ublic Roads, entitled "Public Roads," and the transactions of various national societics.

A research information service supplied by the Advisory Board on Highway Research would require financial support beyond the present budget of the Advisory Board. Whether the service would be self-supporting by sulscriptions from the state highway commissions and other organizations is a matter for examination. The Director again suggests this project for careful consideration. Such a service should not be limited to materials of construction or to the design and construction of the road bed, but should embrace the mutual relations of road and rehicle, the economies of highway location, the operation of loads and all elements of highway transport.

\section{MELTINGS OF THE EXECUTIV COMMITTES}

A meeting of the Executive Committee was held on 'T'hurslay, November 23, 1922 .

Present: Chairman, Dean Inson Marston; Messs. Crane, Spraragen (representing Mr. Flinn), Director IIatt.

Various routine matters were discussed. I budget of $\$ 36,000$ was approved for the year January 1, 1928, to December 3, 192:. Of this amount $\$ 20,000$ was not in sight. I project for the appropriation of $\$ .500$ for establishing a Findex file of highway rescureh workers in the offiee of the National Researeh Comneil was diseused without recommendation.

I report of the Committee on Nominations for the Executive Committee of the Board was received and ordered placerl before the mecting of the Advisory Boart.

1 meeting of the lixecutive Committee was held in IVashingtom. D. C., on July $30,1922$.

Those present were ('hairman A. N. Johnson; Mestrs. ('lanon. Flinn, MacDonald and Director ITatt.

The resignation of Dibretor I Iatt was acepted, to take effect on the date mutually aspeed mom by the Director and the Chairman of the lixecutive Committee.

Provision was marle for the employment of a full-time terluniral assistant.

I resolution was pased loy the Executive Committee expressing the appreciation of the Arvisory Board to the oflicers of Purdue University for their conferation with the work of the Advisory Board ly glauting Inector Talt a leare of alsenee for the past wo years and 
expressing to Director Hatt a sense of deep regret that he was unable longer to continue as active head of the work of the Advisory Board.

Amendments to Sections $6 a$ and 7 of the By-Laws were authorized for submission to letter ballot.

Upon the authorization of the Executive Committee, Chairman Johnson and Director Hatt recommended to the Executive Committee that Mr. E. R. Olbrich, construction engineer, North Carolina Highway Commission, be appointed as Technical Assistant to the Director. The appointment was made by the Executive Committee.

\section{AMENDMENTS TO BY-LAWS \\ Ixcrease in Executive Committee}

On August 4, 1923, the Executive Committee submitted the following amendment to the By-Laws: Section $6 a$, ehange the word "three" to "five." The amended section will then read:

Section 6a. "Executive: Consisting of the chairman, the vicechairman, and five additional members chosen by the Board, at least two of whom shall also be members of the Division of Engineering."

Add the following: "Should a vacancy exist in the Executive Committee it shall be filled by a vote of the remaining members."

The amendment was adopted by the following rote: Yes, $24 ; n o, 0$.

Term of Senice of Members of Researcil Commitees

On the authority of the Executive Committee, the following amendment to the By-Laws was submitted to a vote of the Advisory Board, March 10, 1923:

"Nembers of the Research Committees of the Advisory Board are appointed for a term of three years; at the expiration of the term of office they are eligible for reappointment.'

This amendment was adopted by the following vote: Yes, 20 ; no, 1 .

On August 4, 192:3, the following amendment was submitted by the Executive Committee to a vote of the Advisory Board. Add to Section 7 the following: "The term of services of members of Research Committees shall be limited to one year, but they are eligible to reappointment."

Vote-Yes, 24; no, 0.

The complete section as amended will, therefore, read as follows:

Section 7. "Research Committees: Shall be created by the Board, as deemed necessary, with the approval of the Division of Engineer- 
ing. Members shall be appointed by the Chairman with approval of the Exceutive Committee, and need not be limited to members of the Board. 'The term of services of members of research committees shall be limited to one year, but they are eligible to reappointment."

\section{RELATIONS WITH O'THER ORGANIZATIONS}

Exo Foundation

I resolution was passed by the Executive Conmittee December 2, 1922 , by letter ballot:

"The Executive Committee of the Advisory Board on Highway Research recommends that the Eno Foundation take up the study of the leading principles of traffic handling and traffic regulations and offers the services of the Adrisory Board in a liaison of this work with the constituent organizations, and the publications of the Advisory Board as a channel of commmnication for the reports of this study."

\section{Highwy Gofcation Boaki}

The following subjects for researeh were submitted to the Adrisory Board by the Highway Education Board:

a. In highway economics and highway sociology, in metropolitan and urban highway and highway transport problems.

b. In highway traftic in connection with the lino Foundation and other organizations.

c. Cooperative studies between representatives of motor trucks and the railroads.

d. In highway finance.

e. In highway legislation with special reference to uniformity of codes and the aroidance of conflict of laws.

\section{Americax Sochety of Civil Exgineers}

The American Society of Civil Engineers has appointed an Advisory Committee on Civil Engineering Research to cooperate with the Lngineering Division of the National Researeh Council. It is understood that this committee of the Imerican Society of Civil Engineers, acting in this capacity, is a sponsor of research in the civil engineering field.

The American Society of Civil Engineers has also a Committee on Research and special committees on Highway Engincering and on Impact and Highway Bridges. This latter committee has presented a progress report, published in the March. 192:3, Proceedings.

It the first meeting of the Idrisory Board on Highway Research, on October 8, 1919. a recommendation was made for the appoint- 
ment of a committee on Highway Bridges and Culverts, and the ByLaws adopted November 11, 1920, specify a research committee of the Advisory Board on Highway Bridges. During the past year considerable discussion has taken place between the Advisory Board and the Committee on Impact and Highway Bridges of the American Society of Civil Engineers concerning mutual support in this field of research. The Advisory Board should not organize its Committee on Highway Bridges until the possibility of useless duplication of work is eliminated.

Tize Society of It Iomotive Exgineers

After mature discussion of a combined attack upon relations of road and vehicle, a research project has been adopted on the part of representatives of the Automotive Engineers, the Rubber Association and the U. S. Bureau of Public Roads. This project is now under operation at Arlington, Va., and will be discussed in the report of Committee No. 2 on Structural Design of Roads.

The Committee on Sulgarade of tile Former Federal Highwat Council

Letters have been exchanged between the Director of the Advisory Board and those interested in the work of the Committee on Subgrade of the Federal Highway Council looking to a mobilization of the activities of these two organizations. No definite result has as yet been attained.

\section{National Traxsportation Institute}

The National Transportation Institute is devoted to the work of assembling information on problems of national transportation and distributing this information to the publie. The Research Council of the National Transportation Institute is located in Washington and has functions described by its title. The Jepartment of Public Relations of the National Transportation Institute will communicate to the public, through the various channels of broadcasting, newspapers and magazines, only such information as is endorsed by the Rescarch Council of the National Transportation Institute. The Director of the Advisory Board has called the attention of the National Transportation Institute to the work of the Advisory Board on Highway Research in the field of highway transportation. If the Advisory Board on Highway Research oceupies its special field with energy, it would seem that the Research Council of the National Transportation Institute might accept the output of the Advisory Board. 
AMERICAN RoAd Bullders Issociation

This friendly organization has appropriated a sum of one thousand dollars for the support of the Advisory Board on Highway Research, for which the Board is grateful.

\section{Highentixg FOUNDATION}

The Director of the Engineering Foundation, Mr. Alfred D. Flinn, is vice-chaiman of the Executive Committee of the Advisory Board. Ilis long-continued interest in the work of the Advisory Board has brought about helpful relations between these two organizations. The Engineering Foundation has also appropriated a thousand dollars for the support of the Advisory Board.

\section{U. S. Iitreat of l'uthic Roads, Departalext of Agriculture}

The main support for the operations of the Advisory Board is from the U. S. Bureau of Public Roads. Without the sympathetic and active support of the Bureau of Public Roads, through Mr. Thomas H. MaeDonald, Chief, the Advisory Board conld not have functioned.

REPREAENATIVES OF CONSTITUENT ORGANHZATIONS

The Fxecutive Committee, on March 10, 1923, adopted the following resolution:

"It is the sense of the Executive Committee of the Advisory Board that interest in the work of the Board would be more widely spread if the terms of service of the official representatives of constituent organizations of the Board were limited to three years."

\section{MELTINA ()F THE COMMITTEE CHAIRMEN}

A meeting was held at Atlantic City, Jume 30, 1923. Present: Messrs. Age. Goldheck, Mattimore, Root, Chairman Johnson and I)irector Hatt.

A meeting was held at Richmond. Va., on October 17, 1923. Present: Messrs. Goldbeek. Hamlin, MeKay, Mattimore, Chairman Johnson. Director Hatt and Mr. Olbrich.

\section{FUNCTION OF RESEARCH COMMITTEES}

The following definition of the function and field of activity of Research Committees of the Advisory Board was formulated and approved by the Executive Committee in March, 1923.

1. The entire purpose of the Advisory Board on Highway Research is to render service to investigators, and to accelerate progress in the attack mpon important problems of highway transportation. 
The Board aroids any attitude of proprietorship in the researches which form the subject-matter of the deliberations of its committees, or of any control or direction of the individual research worker, whose initiative and freedom are necessary conditions of his work. Coordination of research is attempted, inspiration given to those who are at work and the broad interests of research advanced by reasonable publicity concerning activities. Information of work under way is spread abroad, so that seekers after knowledge may know where to find it; communication is established between fields of research, as for instance, the vehicle and the road.

2. Research committees do not formulate standards of methods of test or approved practices in construction.

3. Reports of these research committees are not channels for publication of investigations, although a summary of established conclusions from published investigations should appear in the reports to show the status of research.

4. The unique work of the research committees of the Advisory Board is:

a. To bring together research men working in the same field in order to reach a definition of objectives and to bring to each a knowledge of the technique and progress of his fellow-workers.

b. To assemble and review the published data of investigations, or the data placed at the disposal of the committees, for the purpose of judging the extent and stability of the research basis for standards, or for the principles and laws underlying the field of the work of these committees.

c. To study needed and profitable research activities.

d. To stimulate competent agencies to perform research in such fields.

e. To prepare working plans for specific researches in cooperation with inrestigators or for submission to research agencies.

$f$. To call the attention of the Executive Committee to researches which need financial support and to recommend a means for securing such support.

g. To publish information of researches under way, and of the tools of research, as instanced in Bulletin No. 21, entitled " $A$ Census of Highway Research Projects in the United States," published by the National Research Council. 


\section{IA. PUBLICATIONS}

Since the second annual meeting of the Arrisory Board the following publications have been issued:

1. National Rescarch Council Bulletin No. 21, "Highway Research Projects in the United States," containing a description of 479 highway research projects classified by a decimal ststem.

2. National Researeh Conncil Bulletin No. 32. "Proceerlings of the Scoond Anmual meeting of the Arvisery Board on Highway Research," containing an account of the revelopment of the Idvisory Board, its officers and its constituent organizations, and giving leports of research committees.

:. National Research Council Bulletin No. 8.). "Apparatus C Eed in Highway lieseareh Projects," containing lescriptions and drawings of apparatus that have been successully used in the prosectltion of highway research.

For convenience of reference, a list of 15 articles and 26 a lidresses by the Director since August, 1921, is appended.

\section{IVAYS AND MEANS}

The By-laws of the Adrisory Board provide for a Committee on Ways and Means, which has been appointed but has been inactive.

Shortly after the formation of the Adviso:y Board. Fice-Chairman Flinn planned to cireularize a number of prospective contributors to the financial budget of the Advisory Board, but the poliey of the Board in respect to this matter was not settled. It appeared wise afterwards to look to ollieial sources, such as State Highway Commissions and Federal organizations, for the main support. While the Connecticut Highway Commission aided the Board with an appropriation for a period of two years, the desire of other commissions to take similar action was checked by legal harriers. 'These state highway commissions have heartily cooperated in the researeh program of the Advisory boarl and members of their teehnical statts have given good service on our rescarch committees.

It the suggastion of the Director. antributions of money and equipment have been made by industres to researel projects that were languishing and to which the hrvisom lioard was asked to give assistanee. In such ases the funds are not landled by the Adrisory Board. The only responsibility the Director takes is in a matter of judgment as to the probable suecess ul management of the research. In this way the Board. withont funds of its own, (an assist in sup)porting researeh.

I field of work remanding direet expenditure of the funds of the 
Board is in holding conferences of research workers for the purpose of agreement on objectives of research and : !pon boundaries of fields of action. This fruit ${ }^{\circ}$ ul service, together with the expenses attending meetings of the research committees, could be extended if funds were available.

The preparation of Major Ireland's thesis on results of Quartermaster Tractive Resistance Investigation referred to by Professor Agg in Report of Committee No. 1, has involved an expense out of all proportion to that normally expected to be borne by a candidate for a degree. The Director of the Advisory Board recommends that funds be raised in the amount of $\$ 5,000$ for the duplication of the thesis and the reimbursement of the accumulated deficit of this research.

LIST OF PAPERS AND ADDRESSES, JULT, 1921-NOVEMBER 9, 1923 BY W. K. HATT, DIRECTOR

(*) denotes published article.

No. Date Title 1921 * 1 July $27 \begin{array}{r}\text { Program of Highway Re- } \\ \text { search. }\end{array}$

* 2 Sept. 1 The need for Highway Research.

* 3 Sept. 12 Discussion of Highway Research.

4 Oct. 21 Highway Research.......

* 5 Dec. 8 Coordination of Highway Research.

* 6 Dec. 11 Research in $\mathrm{Highway}$ Transport.

1922

* 7 Jan. 16 Highway Research........

$S$ Jan. 18 Report of Director. Advisory Board on Highway Research.

* 9 Jan. 20 Discussion on Research in Highway Transport.

10 Jan. 24 Discussion on Research in Highway Transport.

11 Jan. 25 Highway Research Projects

12 Jan. 27 Higliway Problems.......

*13 Feb. 14 Report of Committee on Research. Report on IBall Test for Concrete and on Fatigue.
Where Published or Delivered

Conference on Highway Economics. University of Maryland.

Public Roads.

Western Society of Engineers. Chicago.

Engineers Club of Philadelphia, City Paving Conference.

American Association of State Highway Officials. Omaha.

Oakland, Calif., Tribume.

American Road Builders Association.

Annual Meeting of Adrisory Board.

American Society of Ciril Engineers.

Highway Education Conference. Lexington, Ky.

Illinois Society of Engineers and Surverors. Decatur, Ill.

Purdue University Road School. La Fayette, Ind.

American Concrete Institute. Cleveland, Ohio. 
Highwaly Research.......

Boston Society of Engineer.

16 April 17 Recent Development in Work of Advisory Board.

*17 May - A survey of the Field of Highway Research.

*18 June $S$ Review of Highway Re- Automotive Industries. search.

*19 Jume 21 Progress in Highway Reseatrch.

20 Jume 23 Progress in Highway Research.

21 Oct. 18 Addres

The constructor.

leport of Inivisin of lingintering, N. R. C.

Highways Green Book. 19:2.2.

A. S. C. F. Portsmouth, N. H.

Society of Autumotive Engineers. White suphur siprings. Student Chapter. A. S. C. F. Massachusetts Institute of Technology.

20 Oct. 19 Address $\ldots \ldots \ldots \ldots \ldots \ldots$ Yale Universityr.

*23 Oct. 26 Research in Highway Elution.

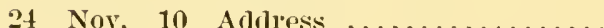
econd Anumal Couference of Highway Educational Board. Waslington, D. C.

Student Society. University of Pennsylvania, P'hiladelphia.

25 Nov. 15 Address ............. Student Society, La Fayette College. Easton, I'a.

26 Nov, 16 Address ............

Student Societr, Iehigh University. South Fethlehem, Pa.

*27 Nov. - Census of Highway Research Projects in U. S.

Bulletin No. 21, National Research Council.

*25 Nor, 21 Repolt of Director, Advisory Foald on Highway Reseal'ch.

*.29 Noy. 21 Aspects of Research......

*:0 Dec. 1 Moot Questious in Highway lesearch.

1923

*:1 Jan. 16 How Individual Organizations Can Fit Their Work into a Froad Highway Research r'rogram.

32 Jan. 16 Address on Highway Research.

Second Anmual Conference of the Adrisory Foard.

Association of Land (irant Colleges. Washington, D. C.

P'rinceton University. Reprinted in "Rock Products." March 10, 19:2.

American Road Builders . Issociation. Chicago. Ill.

Crushed Stome Association. Chicalgu. I11.

*3\% March - Research Foundation for the Eeonomic Theory of Highway Improvement.

*:it March - Highway lesearch.......

*ar May 8 Report on Higluway ReCornell Civil Engineer. search I'rojects in U. S. 
No. Dute

1923

*:36 Jume - Proceedings of the Second Annual Neeting of the Advisory Board on Highway Research.

*37 Jume - Research c'mmmittees......

*38 Jume 28 International Road Congress, seville.

39 July 11 Opening Statement, Division of Highway Engineering, A. S. C. E.

40 Nor. 5 Scientific Research in the Highway Field.

41 Nor. - Coordinated Transportation

4.2 Nor. S Report of Director to the Third Annual Meeting of the Advisory Board on Highway Research.

Where I'ublished or Delicered

Bulletin No. 32, N. R. C.

A. S. T. M., Atlantic City. Reprinted, "Science," September $19,1923$.

Engineering News-Record.

Convention of A. S. C. E. Chicago.

I'urclue Branch of Sigma Xi.

Purdue Unirersity Engineering Review.

Washington. D. C.

The report of the Director was accepterl.

\section{REPORT OF COMMITTEE NUMBER 1, ON ECONOMIC THEORY OF HIGIIWAY IMPROT W.MENT}

In its present form the committee is made "1) of men actually engaged in research activities and of engineers who al'e able to assist in the organization of research or in the evaluation of data obtained in the progress of the various actrities of the committee.

There has never been a meeting of the full committee, but rarious members of the committee have met occasionally in connection with some scientific or technical convention.

The committee is really an informal asscciation of men engaged in a certain line of research, and no attempt to supervise the work of the individual members is made by the chairman of the committee. but he does attempt to aid investigators who find their work handicapped in some way. Generally, financial assistance is needed, but it has not always been available. An attempt is made to interest new personnel from time to time and to expand the research work in the field of highway ecomomics. Duplication of effort is eliminated by the publicity given the projects that are inaugurated from time to time.

There is presented herewith a chart which shows the field the committee seeks to cover and the progress that has becn made up to the present time. 


\section{I'ROJECTS COMPLETED}

The following projects in the field of IIighway Economies have been completed and the results have been published or are in progress of publication at the present time:

\section{No. 1. Treck Perforalax'e on Grades}

This research was organized under the direction of Frank F. Rogers, Commissioner of Highways of Michigan, who assigned Victor R. Burton. in his organization, to the project. The work was carried out with the cooperation of the Lniversity of Michigan, which was represented by Walter E. Lay, Iscistant Professor of Mechanical Engineering. ${ }^{1}$

\section{No. 2. Rolling Resistaxce ani Related Cimbacteristics of ROADWAY SURFACES}

The research was conducted as a cooperative project, in which the U. S. Bureau of Public Roads, the Iowa Highway Commission and the Iowa Engineering Experiment Station participated. ${ }^{2}$

\section{No. 3. Ecovomis's of HighwiY Grades}

This investigation was condueted by the Iowa Engineering Experiment Station, with some cooperation from the Iowa Highway Commission. ${ }^{3}$

\section{No. 4. Sub-comaltetee on Tractive Resistance}

The events leading up to the formation of this sub-committee of Committee No. 1 are as follows:

In February, 1920. Major Mark L. Ireland, Q. M. C., was appointed a member of Committee No. 1. Shortly after entering Massachusetts Institute of Technology in September, 1920. as a graduate student. he recommended to the Quartermaster General a research project on tractive resistance. In May, 1921, he began the preparation of a bibliography on tractive resistance. In August overtures were made to the Mason Laboratory of Yale University for laboratory tests on vehicles. In September, Prof. Adams, then Chairman of the Division of Engineering, and Mr. A. D. Flinn,

\footnotetext{
${ }^{1}$ The results of the investigation were published in "The Proceedings of the Eighth Annual Conference of Highway Engineering," held at the University of Michigan. Reguests for copies may be addressed to Commissioner Rogers or to Professor Iar.

${ }^{2}$ Bulletins 64 and nit of the Iowa Enrincering Experiment Station, Iowit State College, Ames, lowa.

${ }^{3}$ Bulletin fis of the Iowa Enginerring Experiment Station. Iowa State College, Ames, lowa.
} 


\section{PROJECTANo PROGRESS CHART of HIGHWAY INVESTIEATIONS}

COMMITTEE ON HIEHWAY ECONOMICS - DIVISION OF ENGINEERING - NATIONAL RESEARCH COUNCIL

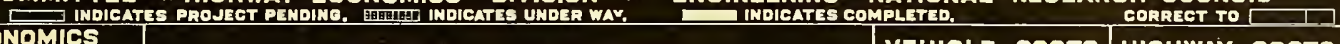

GORREGT TO

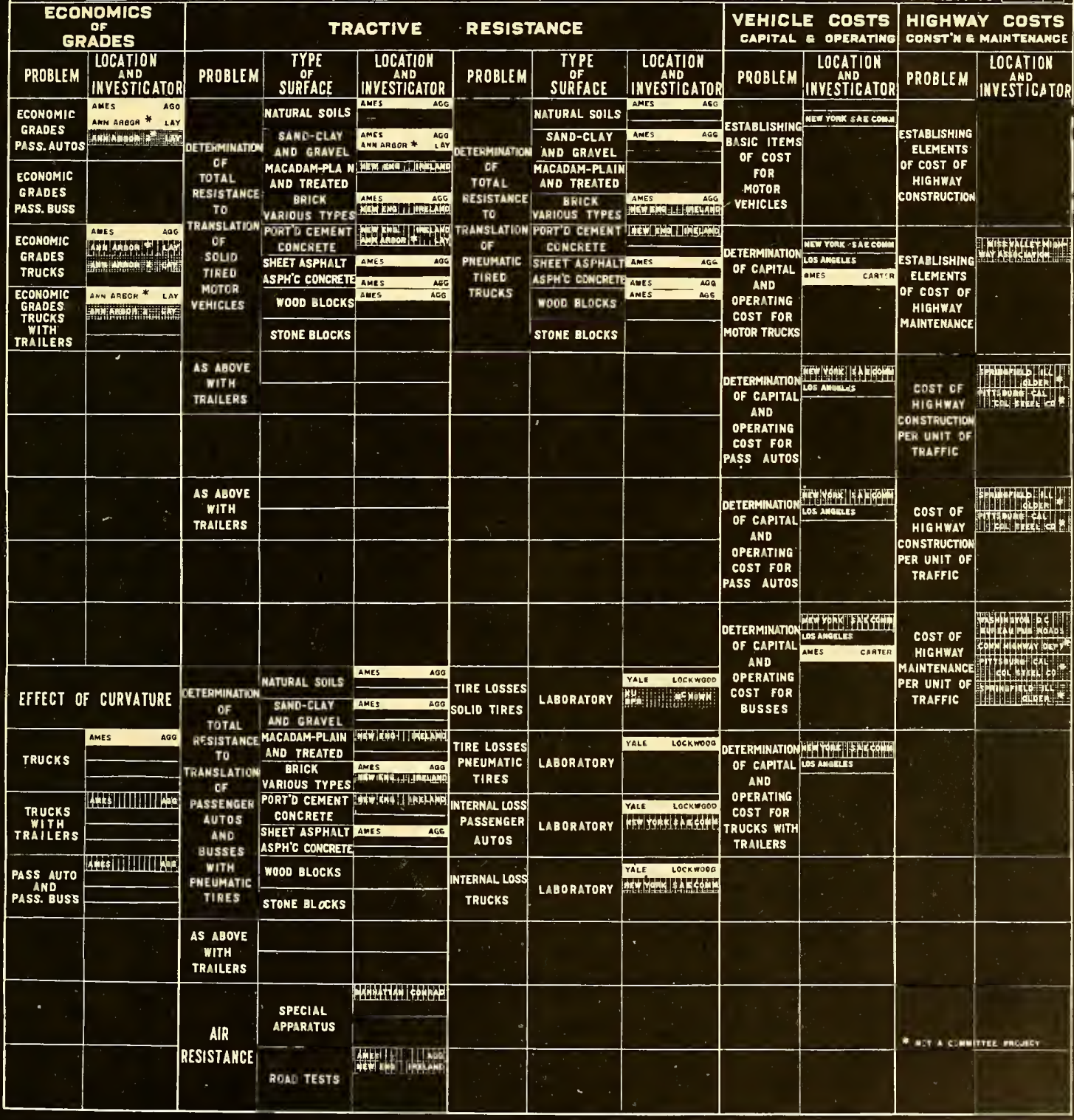



prepared a circular letter asking support for Major Ircland's researches then under way. On September 23, 1921, the correspondcnce and administration concerning this research, to which the Division of Enginecring was rendering assistance, was assigned to Director Hatt, who organized a sub-committce of Committee No. 1 under chairmanship of Prof. Adams, consisting of the following persons directly interested in the research: Prof. C. A. Adams, Harvard University; Prof. T. R. Agg, Iowa State College; Commissioner Chas. J. Bennett, State of Connecticut; Commissioner John N. Cole, State of Massachusetts; Dr. H. O. Dickinson, Society of Automotive Engineers; Mr. A. T. Goldbeck, U. S. Bureau of Public Roads; Major Mark L. Ireland, Q. M. C., U. S. Army; Prof. D. C. Jackson, Massachusetts Institute of Technology; Prof. E. N. Lockwood, Yale University. Contribution of funds, instruments and equipment were supplied by the following partics:

Quartermaster Corps and Air Service, U. S. Army.

Bureau of Public Roads, U. S: Dept. of Agriculture.

Massachusetts Institute of Technologir.

Yale University.

Comnecticut Highway Commission.

Massachusetts Department of I'ublic Works.

International Motor Company (Mack Trucks, Inc.)

\author{
United States Rubber Company. \\ Portland Cement Association. \\ Barber Asphalt Company. \\ Locomobile Company of America. \\ Goodyear Tire \& Rubber Company. \\ Filestone Tire \& Rubber Company. \\ Kelley-springfield Tire Co. \\ Blanchard Instrument Company. \\ Schwarz Wheel Company. \\ Iowa State College.
}

Nuch valuable assistance in a consultative capacity was rendered by many other interests quite too numerous to mention, with full assurance of making the acknowledgment list complete.

The corps of research workers, in addition to Major Ireland, Director of the Quartermaster Tractive Resistance, included Capt. F. I. Maslin, Q. M. C., First Lieut. Herbert C. Mitchell, Q. M. C., Mr. Wm. O. Tait, Special Asst. (Automotive Engineers), U. S. Burean of Public Roads. Mr. Ralph M. Trimble, and Mr. A. Fleischer, who resigned and was later replaced by Mr. H. F. Gleason, Junior Civil Engineers, U. S. Burcau of Public Roads, and two Q. M. C. experimental truck drivers. The two driver positions were filled by consecutive appointment of Massachusetts Institute of Technology graduates and ex-students from available candidates. A number of part-time students were also employed from research funds. Later, Chairman Adams resigned and Prof. C. J. Tilden, Yale University, was elected chairman, Prof. Adams continuing as a member of the sub-committee. The investigation represents an expenditure for salaries, services and other tangible items, of considerably more than 
$\$ 40.000$. Sulability of instruments and technighe of tractive resistance hare been carefully studied. I litge rolume of valuable data has leen acemmulated. covering both rolling and sliding fricefion besults on some 10 vilpoties of road sulface of varving age and state of maintenance. emploving six types of heary motor vehiches at fyeeds as high as tt miles per hour with ango loads from 0'; to $150 \%$ of the rated capacity at all satoons of the rear and under partically all wather conditions. and utilizing valious types and varicties of steel, solid rubber and pnemmatic tires, new and worn. Some of these data have appeared in the preliminary reports of the three officers of the Quatermaster ('orps.

considerable difticulty has bern experienced in arljusting the length of the time. program of tests to arablate fumbs and the direrent needs of the many conoperative interests. The molat ricisifucse of reseanch work. all of which make for delay. have been en(omutored, suc. as insuthicient funds. administrative detail requiring fine and pationce to adapt to the situation of a temporaty eo-operative oreanization on a new and somewhat mustal mis-ion which required development of instruments and methods. The progress and the results achieved, howerel, have been commensmate with the time. energy and funds expended and the thoroughness whidh should be obsered in so expensive an undertaking.

On November 27. 1922. Major Irelaud and Captain Maslin were transfered to the Eniversity of Michigan. In June. 1928. Major lreland receired from that institution the degler of Doctor of Philosophy, on the basis of study and a thesis embodying about onehalf of the data aceummlated by him while at the Massachusets lustitute of 'Toelmology. His two-rolume Preliminary Report and also a slowt one by Lientemant Mitchell are before vou now. The

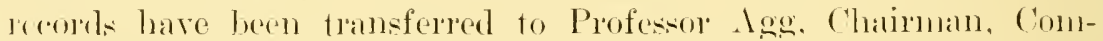
mitter No. 1, for completion and final report in co-operation with Major Treland and (aphain Mastin. Major lreland is complying with an Iret of Congless which reguires a year of service with troops at stater intorvals.

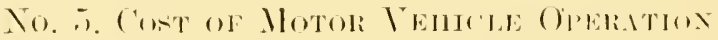

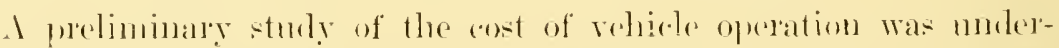
taken ly the Civil Enginecring lepartment, lowa state College. moler the direction of II. S. Calter. who was at that tine a graduatrestudent in highway angineering. Ilis work was of most vahue in indicating some of the difticulties involved in surh astuly and in pointing ont the dibection in which the work combl best proceed. IIe rlid, lowerer, secture comsiderable valuable data, and it is expected that this material will be mblished before the whe of the reats. al- 
though I camnot at this time announce who will sonsor the publication.

\section{IROJECTS IN PROGRESS}

'The following projects have been in progress for longer or shorter periods of time. Progress reports are submitted for several of these projects.

\section{No. 1. Wixd Resistaxe on Motor Vehicles}

Report by Prof. L. E. Conrad, of the Engineering Experinent Station, Kinsas State Igrieultural College

Professor Conrad was mable to be present to report in person. The report is as follows:

The investigation of wind resistance of antomobiles was undertaken some two years ago by the Engineering Experiment station of the Kansas State Igricultural College. The problem was undertaken at the instigation of the National Rescarch Council, but from a financial standpoint the only cooperating agency las been the L. S. Bureau of Public lioad-.

The original apparatus, in addition to a number of small instruments. included two circular tanks of heary galranized iron. The larger of these tanks, 17 feet in dianneter and 312 feet deep, is placed in the ground at such a depth that the top edge is level with the ground surface. This tank is partially filled with water. in which the smaller tank Hoats. The smaller tank. which is 16 feet in diameter and 2 feet deep. has a wooden deck, on the top of which the antomobile is placed. The water level is arljusted so that the top of this deck is level with the ground surface.

The additional instruments refered to arr an anemometer, a stopwatch, a thermometer. a barometer, four weather vanes. and the recording mechanism. The recording mechanism is merely a device for recording on a chart the pull which the wind exerts on the automobile, as measured hy the tendency of the float to move away from its initial position.

The test is macle as follows:

(1) The automolite is run on to the float deck and blocked in the proper position.

(2) After a careful study of the weather ranes the float is turned until the ear heads directly into the wind.

(3) The recording mechanism is located on the float directly in front of the automobile. I wire which laads from the reeording mechanism is anchored to a short pipe set in conerete near the edge of the large tank.

(4) Four stay-ropes are connected to the float at right angles to the 
direction of the wind. These ropes prevent side sway of the float, but can exert no force in the direction of the wind.

(5) It a given signal, one observer starts the anemometer and the other observer starts the motor which moves the chart. The observer at the anemometer records the number of feet of air passing through the anemometer each 30 seconds. It the end of the test, which runs for six minutes, both instruments are shut off and readings are taken of the anemometer, barometer and thermometer. If the wind direction shifted materially during any portion of the test, a note is made of the time, and later that portion of the test is discarded.

Because of the variable intensity of natural winds, it is necessary to average the results of the records over a certain time interval. The determination of this time interval constitutes in itself a research problem. 'The shorter the interval, the greater will be the accuracy; but physical limitations in instrument reading, recording, etc., make any interval less than thirty seconds impracticable. The thirty second interval was therefore adopted.

The records are worked up as follows:

The charts are divided into twelve sections, each representing thirty seconds of time. These areas are then traced with a planimeter and the average ordinate is determined by dividing the area by the length of its base line. This ordinate to scale represents the average pull over the thirty second interval. This pull after the temperature and pressure corrections have been applied, together with the corrected wind velocity, locates a single point on the velocityresistance curve. Due to the gusty character of winds, these points are somewhat sattered, and it was found necessary to determine, by the method of averages, the equation of the theoretical curve most nearly fitting the points.

Br applying this method to orer 400 points the equation $\mathrm{F}=$ $0.0012 \Lambda . V .2 .383$ was obtained. $(\mathrm{F}=$ pull in pounds; $\mathrm{A}=$ projected area in square fect; $V=$ wind velocity in miles per hour.) The results of aeronautical investigations indicate that the value of the exponent should be two. The results of Riedler on the "Scientific Determination of the Merits of Automobiles" indicate for the coefficient a value of about 0.003 .

At this stage of the inrestigation it became evident that a greater refinement would be necessary. For a number of reasons, it was evident that this refinement would be expensive if natural winds were used, and therefore our attention was directed toward some means of producing an artificial wind.

After considerable study and investigation, it was decided to 
build a wind-tunnel of sufficient size to test full-sized automobiles. This wind-tunnel, which is now nearing completion, differs from the usual type of wind-tunnel in two respects: First, the cross-section is rectangular instead of eircular; second, the testing portion, where the ear is placed, is enlarged in order that the air speed in this section will not be increased by the presence of the car. The cross-section of the tunnel ahead of the enlarged portion is approximately 12 feet wide by 10 feet high, while the entire length is about 40 feet. The enlargement, which is made on the two sides and top, is approximately 9 inches, making the test portion of the tunnel approximately 10 feet 9 inches high and 13 feet 6 inches wide. The amount of enlargement was calculated from the average of the projected areas of a large number of different kinds of antomobiles. This area was traced with a planimeter from a plot of the car made with a camera lucida. The entrance of the tunnel is flared to admit the air freely, the size of the opening being $121 / 2$ feet high by 17 feet wide. The exit end tapers down to a circular section 10 feet in diameter. An ordinary airplane propeller is used for a fau.

The platform on which the ear is tested rests on long beams supported by ehains from an outside framework. The zero position of the platform is determined before the fan is started. The fan is then started and, as the wind velocity is increased. the pull required to return the platform to its zero position is determined for each increment of velocity.

Although, up to the present time, no complete tests have been made, enough data have been taken to indicate that the tunnel may be expected to give satisfaetory results. A wind velocity of sixteen miles per hour has been obtained, and a study of streamers placed at various points in the tunnel indieates that the air currents are suffieiently uniform for our purpose. The chief diffienlty at the present time is the laek of a fan of the proper design. We have at present a combined motor and propeller efficiency of less than 20 per cent. A propeller of considerably less pitch than those used for flying is required. but such propellers, apparently, are not made except as special orders at prohibitive prices.

At the present time the roof of the tunnel is being strengthened, so that the ears may be suspended from the roof immediately above the platform to determine the resistance of the platform itself.

The problems for the immediate future are:

1. To design and build an adjustable piteh propeller having eight blades.

2. To determine the correction necessary to compensate for the effeet of the wind on the platform. 


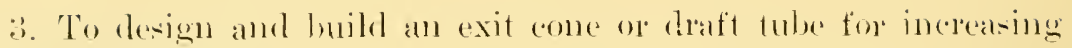
tumnel efficiency.

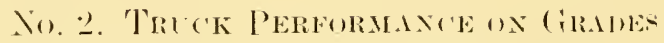

lieport hy Profesore IV. E. Ialy

sinese this is a report of progress, and as steh semes rather inadequate, it appears arbisable to sketch in briefly the history of reseatreh work on war and truck performanes at the Lniversity of Mishigan.

This work was begrne in 1915, in a series of tests whose object wals ".To determine the II. P. which must be delivered to the road by the fear wheels of a motor car in ordes to drive it at giren speeds." The problem was attaked by the coasting method. The ar wat driven up to top speed and allowed to comst orex the course, on which were located at given intervals mijs and electric contals which operated pens on a somewhat crude chronograph. The magnitude of the forees resisting the motion of the ats were to be computed from the rate of decoledation determined by twice diflerentiating the tine share data given on the eloronograph dhast. Exen at this time it wat understood that allowance must he math for the deceleration of the lotating parts as well as for the linear deceleration of the whole masis of the rehiede. Crexpected difficulties met in the attempt to

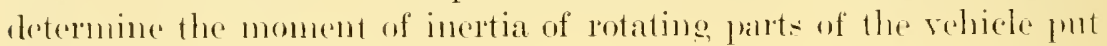
an (m) to the work lom the time.

The following yeat an inplosed chromoglaph was tried ont. to-

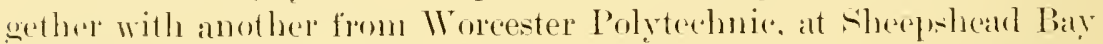

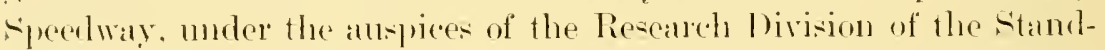
ards Committor of the -. . E. The Worester chromograph was cartrise in the art and gave a reeord of time. and of the space traveled. the latter pen bejug aretuated hy a series of contalets on a frout wheed. From the experience thus sained an improvenent of the ITorester chonograph was erolved which used an ignition timer driven like a specdometer from the front wheel and discharging a high tension spark through the moring chart every one-fifth revolution of the front wheels. The $\$$. I. E. adopted this a the standam methorl of determining the performance of a car.

In 1918 the problem was again taken me and a new elonomograple was built. with many of the details ansiderably impuroved, and a series of tests were miate an a Dodge and a Ford call. One of the drawhates of this mothoul was the tedions amoting of the small holes male ly the spark and the fact that the spark would not jump in a straght line from ane needle point, through the palpese to the othes.

Fanly in 1921. With the conperation of the Michigan state lligh- 
way Department. the problem of determining the prerformance of a rehicle was attacked from an entirely different angle, in that the major part of the data was obtained in the laboratory by laboratory methods and merely a check was made on the road. By this method the characteristics of the power plant and the power transmission system were determined in the laboratory and only the rolling resistance of the rumning gear was determined on the road. The fuel consumption of the truck was determined on the road as a check on the results obtained in the laboratory. Four 3-ton trucks, all of the same model-gross weight, 16,000 pounds-were wsed to give a thoroughly dependable average result. In these tests the greatest difficulty was encountered in detemining the efticieney of the transmission system. I hydraulic dynamoneter of the recording type was also developed to measure directly the rolling resistance of the running gear. I formal report of this work was made in the "Proceedings of the Eighth Annmal Conference of Highway Engineering,. Felmuary, 1922.

There was considerable criticisn among the state highway ongineers to the efferet that the truck was somewhat learier than the average commercial vehicle on our roads: so that early in the rear 192.2 work was again begm on two high-specel 1-ton trucks. wing methods considerably improved. as a lesult of the experience in the previous tests. Since the angines in the light trueks were not governed, a much larger range of speed was covered. In testing the transmision srstem. the engine was renoved and the chassis driven by an electric drnamometer. The ontput at the rear wheels was neasured by Prony brakes and checked ha a reaction dymamometer on the rear axle itself.

In ealibrating the large hydraulic dymamometer it was found that there was some friction in a stuffing box which might seriously affect our results on a very light pull, so a much smaller dynamometer was built which aroided the nse of a stufling bex. Some of this friction still remained. howerer, and at present we are in the process of developing the reaction dynamometer used on the transmission system tests. Instead of nsing a piston and eylinder to change the drawbar pull into liquid pressure, a Fulton pressure element is adapted to that purpose. Since it is a combination of a diaphragm and a bellows, no leakage of the liquid can occur, and as there are no sliding surfaces. friction is reduced to a minimum. We intencled to wse both methods to determine the rolling resistance of the 1-ton truck. 'The reaction type dynamometer has a distinet advantage in that it is self-eontained and the truck npon which it is mounted constitutes an excellent instrument for comparing the rolling resistance over varions 
types of road surfaces, rough roads, curves, ete. Since in determining the rolling resistance of the rumning gear it will be necessary to correct for grade resistance and acceleration or deceleration, a recording accelerometer will be used in addition to the recording reaction dynamometer.

IABLE I.-Inertia Tests. 3-ton Truck

\begin{tabular}{|c|c|c|c|c|c|}
\hline Group & \multicolumn{2}{|c|}{$\begin{array}{l}\text { Equivalent } \\
\text { moment of } \\
\text { inertia, } \\
\text { M. ft. }\end{array}$} & $\begin{array}{l}\text { Aetual } \\
\text { moment of } \\
\text { inertia, } \\
\text { M. ft. }{ }^{2}\end{array}$ & $\begin{array}{l}\text { Weight } \\
\text { of parts } \\
\text { in pounds }\end{array}$ & $\begin{array}{l}\text { Radius of } \\
\text { gyration, } \\
\text { feet }\end{array}$ \\
\hline Two front wheels....... & \multicolumn{2}{|c|}{24.06} & 24.06 & 494 & 1.25 \\
\hline Two rear wheels........ & \multicolumn{2}{|c|}{67.2} & 67.2 & 1304 & 1.28 \\
\hline \multicolumn{2}{|c|}{$\left.\begin{array}{c}\text { Transmission main shaft with } \\
\text { sliding gears, propeller shaft, } \\
\text { universal joints, final drive } \\
\text { and axle shafts.............. }\end{array}\right\}$} & 43.0 & & & \\
\hline $\begin{array}{l}\text { Clutch drum and driven } \\
\text { dises, eluteh shaft and } \\
\text { gear, transmission } \\
\text { eounter-shaft ......... }\end{array}$ & $\begin{array}{l}\text { Gears } \\
\text { 4th } \\
3 r d \\
2 \text { nd } \\
1 \text { st }\end{array}$ & $\begin{array}{r}2.10 \\
4.62 \\
13.84 \\
44.23\end{array}$ & .025 & & \\
\hline $\begin{array}{l}\text { All moving parts of the } \\
\text { engine.............. }\end{array}$ & $\begin{array}{l}4 \text { th } \\
3 r d \\
\text { 2nd } \\
1 \text { st }\end{array}$ & $\begin{array}{r}166.1 \\
365.3 \\
1094.0 \\
3491.0\end{array}$ & 2.05 & & . \\
\hline
\end{tabular}

2 front wheels $r=\sqrt{24.00 \times 32.2}=1.25$

494

2 rear wheels $r=\sqrt{67.2} \times 32.2=1.28$

Gear ratio: 1304

$\begin{array}{ll}\text { 4th } & \text { gear }=9.0 \\ \text { 3rd gear }=13.36 \\ \text { 2nd gear }=23.10\end{array}$

1 st gear $=41.3$

While the truck performance tests were going on we became interested in the effect of storing energy in the rotating parts of a moving vehicle and the relation of this effect to acceleration and deceleration of the vehicle. If a car or truck is accelerated. kinetic energy of translation is stored in the moving vehicle. $\Lambda$ large number of the parts have, in addition to their linear motion, rotative motion, and the connecting-rods and pistous have a very high reciprocating velocity. Thus they have an additional quantity of kinetic energy. By suitable methods the eapacity of these parts to alsorb energy was determined : also a quantity called the equivalent moment of inertia of all these rotating parts. It may he defined as the moment of 
inertia of such an imaginary mass, located in the rear wheels and revolving with them, that would have at any speed the same kinetic energy as the actual rotating parts of the truck.

Thus, when accelerating the 3-ton truck in high gear, we find that 21 per cent of the stored energy will be found in the rotating parts, and in low gear we find over 75 per cent in the rotating parts.

TABLE II.-Comparison of Kinetic Energy of Translation vs. Kinetic Energy of Rotation in Various Gears. 3-ton Truck

\begin{tabular}{|c|c|c|c|c|}
\hline & \multicolumn{4}{|c|}{ Gear } \\
\hline & 4th & 3 rd & 2nd & 1 st \\
\hline Linear speed of truck, miles/hour & & 8.1 & 4.7 & 2.6 \\
\hline And of wheel periphery, feet/second $(v) \ldots \ldots$. & 17.64 & 11.88 & 6.87 & 3.84 \\
\hline $\begin{array}{l}\text { Angular velocity of rear wheel radians per } \\
\text { second }(w) \ldots \ldots \ldots \ldots \ldots \ldots \ldots \ldots \ldots\end{array}$ & 11.63 & 7.83 & 4.53 & 2.53 \\
\hline $\begin{array}{l}\text { Equivalent moment of inertia of rotating parts, } \\
\text { poundal foot: }\end{array}$ & & & & \\
\hline (a) Engine to clutch $\ldots \ldots \ldots \ldots \ldots \ldots$ & 166.1 & 365.3 & 1094.0 & 3491.0 \\
\hline (b) Clutch to neutral. & 2.10 & 4.62 & 13.84 & 44.23 \\
\hline (c) Neutral to rear wheels. & 43.00 & 43.00 & 43.00 & 43.00 \\
\hline (d) Rear wheels...... & 67.20 & 67.20 & 67.20 & 67.20 \\
\hline (e) Front wheels. & 24.06 & 24.06 & 24.06 & 24.06 \\
\hline ( $f$ ) Total-when accelerating & 302.46 & 504.18 & 1242.10 & 3669.49 \\
\hline (g) Total-when coasting ... & $\begin{array}{r}134.26 \\
\text { Accel- }\end{array}$ & 134.26 & 134.26 & 134.26 \\
\hline $\begin{array}{l}\text { Kinetic energy } \\
\text { Of translation, foot-pounds.... }\end{array}$ & $\begin{array}{l}\text { erating } \\
76,950 \\
79.0 \%\end{array}$ & $\begin{array}{l}35,100 \\
69.5 \%\end{array}$ & 11,830 & $\begin{array}{l}3,664 \\
23.8 \%\end{array}$ \\
\hline Of rotation, $\begin{array}{r}\text { foot-pounds. } \\
\% \ldots \ldots \ldots . . .\end{array}$ & $\begin{array}{l}20,350 \\
21.0 \% \\
\text { Coast- } \\
\text { ing in }\end{array}$ & $\begin{array}{l}15,375 \\
30.5 \%\end{array}$ & $\begin{array}{l}12,800 \\
52.0 \%\end{array}$ & $\begin{array}{l}11,720 \\
76.2 \%\end{array}$ \\
\hline $\begin{array}{l}\text { Kinetic energy } \\
\text { Lincar speed of truck, M. P. H...... }\end{array}$ & 12.0 & S.1 & 4.7 & 2.6 \\
\hline Energy of translation, foot-pounds . & 76,900 & 35,100 & 011,830 & 3,664 \\
\hline Energy of rotation, foot-pounds. & 9,050 & 4,100 & 1,389 & 429 \\
\hline & $10.5 \%$ & $10.5 \%$ & $10.5 \%$ & $10.5 \%$ \\
\hline
\end{tabular}

Kinetic energy of translation $=w v^{2}$

Kinetic energy of rotation $=\overline{2} g / 2 I w^{2}$

Weight of loaded truck $(w), 16,000$ pounds.

Truck operating at governed speed (1000 R. P. M.)

When decelerating, this stored energy is used to drive the truck, so that when the truck is coasting with gears in neutral, 10 per cent of the driving energy is furnished by the rotating parts.

When using an accelerometer to determine the rolling resistance by the coasting method, this relation must be known. Of the above 10 per cent, 5 per cent was stored in the rear wheels, 1.8 per cent in 
the front wheels and :3.2 per cent in the rotating pats of the truck between the rear wheck and the transmission nentral.

The method of determining the equivalent moment of inertia was to jack up the rear end of a truck with the rear wheek over a well. Ropes attached to weights were wound on the wheels. The weights were allowed to drop a given distance, nsing their potential onergy to overcome the friction of the rotating parts, to gire the falling weight kinetic enerey of motion, and the rotating parts kinctic encrey of rotation. If the velocity, distance and tine relations are known, equations may be set up and solved for the equivalent moment of inertia of rotating parts. Tables I and II give some interesting data obtained from the 3-ton trocks. Table III gives a comprarison of the results obtained so far on the 1 -ton speed truck with those obtained on the B-ton truck.

TAB1.E IHI.-Comparison of Results Thus Far

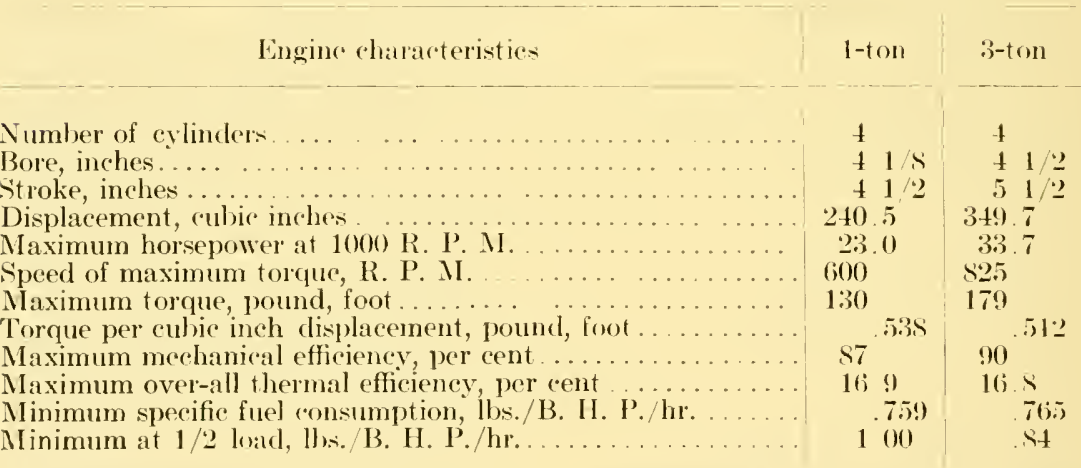

Transmission System Charactoristics

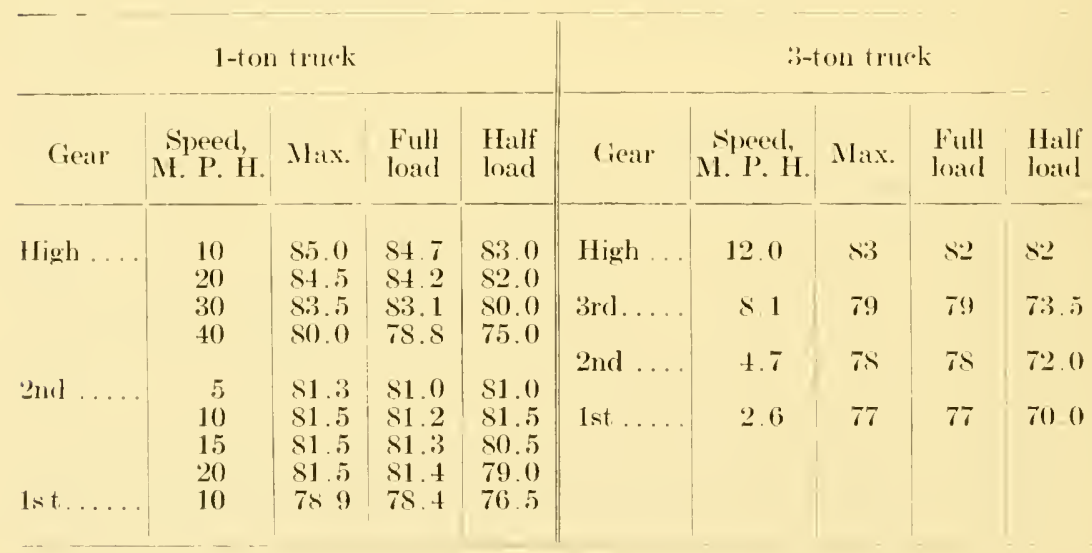




\section{No. :P. Rematon of Rold Trpe to The ITear}

Report by Professor IV. C. Mc Nown

Pupose.-In the selection of a type of surface for a road it is necescary to take into account not only first cost and cost of maintenance, but also the eftect of that trpe upon the cost of rehicle operation. Tnasmuch as fire wear causes one of the major items in motor rehicle operation cost, it is desirable to know the relation of road surface to it. Such is the purpose of the investigation, the progress of which is here ontliner.

Review of previous worl on the subject of tire wear.-The writer hat made a diligent search for records of previous efforts in the direction of determining the relation of road-surface type to tire wear, not only in engineering literature, but among those research ageneies of the country likely to interest themselves in such a problem. If such work has been done, the search made has failed to bring any record of it to light except in one instance, namely, that of three students working on a Bachelor's thesis at the University of Kansas in the spring of 1922. This rork of H. A. March. IV. B. Wells and F. W. Goodnow, done under the direction of Prof. C. C. Williams. was the forerumner of the present research. The record of this work may be found in the library of the Lniversity of Kansas, in the Bachelor"s thesis entitled, "lielative Wear of Automobile Tires on Brick. Concrete, and Isphalt Parements:" ly March, Wells and cioodnow.

A circular track 59 inches outside dianoter was constructed and was surfaced succesively with the three previoms mentioned surface types. Tpon this track. by suitable mechanism, were run four ten-incly wooden wheels. Around the circumference of each wheel was fastened a strip of rubber wasing material one inch wide which had been cut from a standard automobile tire casing. This wearing strip, was carefully weighed before and after a 100-mile run on each kind of surface and the loss recorded in per cent of total weight lost. Other details are omitted. It suflices to say that the work was done in a satisfactory manner, considering the attendant circumstances. The results are shown in the following table:

Tabıe I. Ier Cent Loss in Wright per 100 Miles. Comsidering Wear of Rent Wheels on Comerete as 100

$\begin{array}{lcc}\text { Surface } & \text { Reur whects } & \text { Front wherls } \\ \text { Asphalt } & 27.2 & 15.3 \\ \text { Brick } & 58.3 & 34.5 \\ \text { Concrete } & 100.0 & 50.6\end{array}$


The plan for the present cooperative test.- It was decided to conduct the test in two parts, one being accomplished on a specially devised piece of laboratory equipment and the other on a Dodge touring car especially equipped for the purpose. This plan was carried out, and what follows will be largely a discussion of the purpose, design, constuction and testing of these two pices of equipment. It became clear very early in the summer that practically the whole season would have to be given to such work, and that little conld be accomplished in the way of ruming a testing frogram. The objective determined upon has been very nearly completed. Such adritional work of getting rearly as neerts to be done will be pushed during the year and, as far as can be foreseen. all difticulties ironed out. so that a program of testing can be started promptly with the opening of next season.

The laboratory apparatus. - This apparatus was designed to handle certain features of the work which could be done only on stationary equipment, or could be done better. cheaper, or more experlitiously in such manner. The following are some of the necessary items of work thought to be best done on it:

(a) Detemining in a standardized situation the individual characteristics of the tires to be used as regards wear.

(b) Testing the effect of under inflation on weal of tires.

(c) Testing effect of moisture on wear of tires.

(d) Testing the eflect of traction on wear of tires.

(e) Testing the relative wear of tires on such surfaces as could be reproduced on such laboratory equipment.

Description of the apparatus.-Cieneral views may be olitained by reference to Figures 1 and 2. A carriage carrying a $12 \mathrm{H}$. P. motor is supported by a single rear Dodge Bros. motor war wheel and balanced by four coiled springs. This motor drives the auto wheel by belt and pulleys and through it drives the concrete shod wheel which constitutes the road. The "road" is connected by belt and pulley to a generator which is wired to load racks. The attendant uses the wattmeter and the loar racks to keep the traction between the auto wheel and the "roar" at a predetermined constant. The carriage carrying the driving motor is carefully balanced by weights. and its weight plus the balancing weights plus the tension in the four stabilizing springs give a weight on the anto tire equal to the weight on a rear wheel on a Dodge touring car whou carrying a normal load or 900 pounds.

The pulley combinations are such that the speed of the auto wheel is held nearly constant at 25 miles per hour. The shaft of auto 
wheel and "road" were each fitted with revolution eounters to check speed, and to be used in the determination of the mileage. The running unit was taken as five hundred miles, and this appears to be about the right amount.

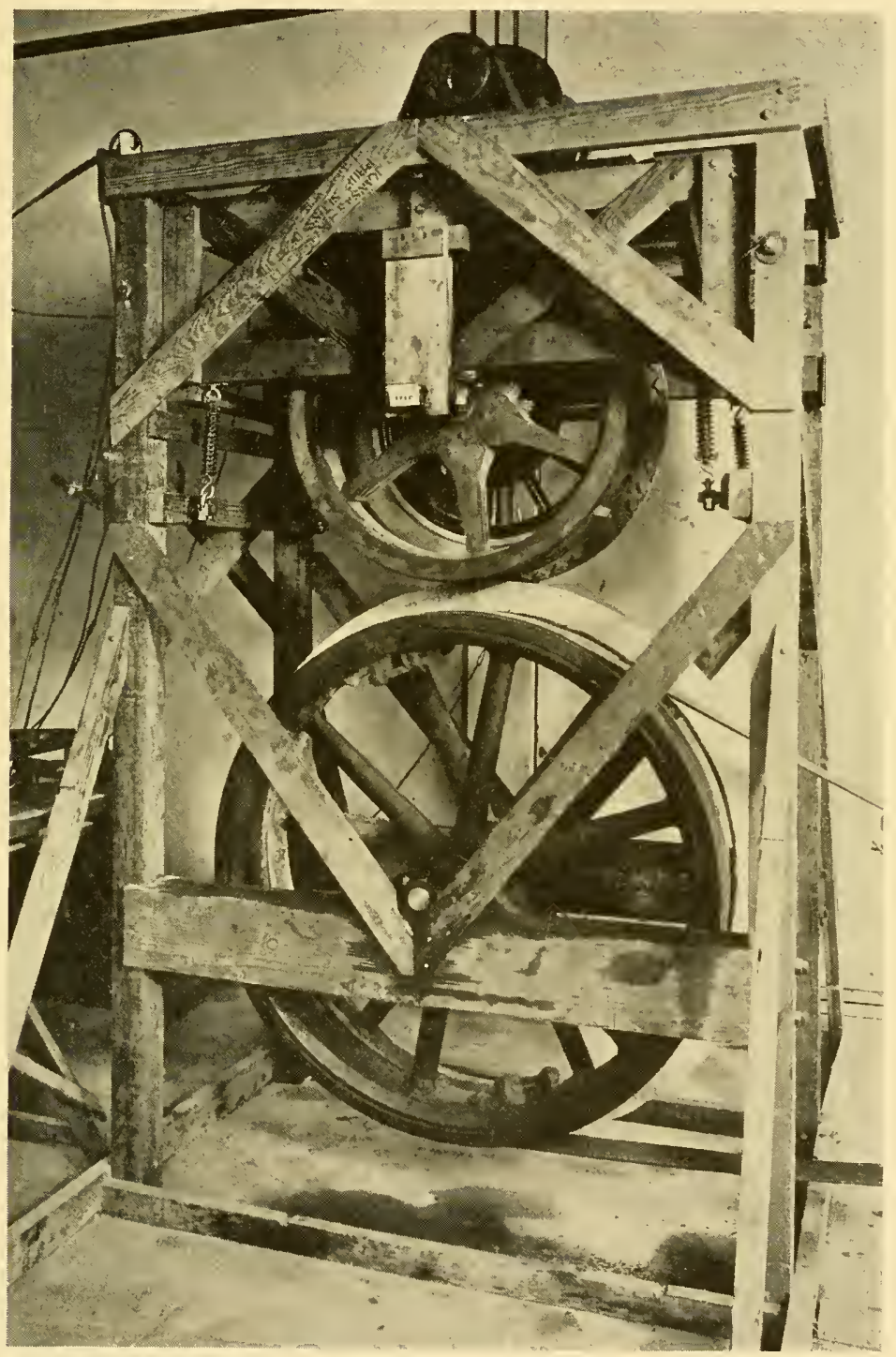

Figure 1. 'Tire testing apparatus used by Professor McNown.

The tires.-The tires adopted are standard for a Dodge touring ear. The Kelly-Springfield Tire Company entered into cooperation on the 
test to the extent of furnishing tive of their stamdard bB :32"xt" ond tires.

The plan was to measure the wear in terms of the losin in weight for a given distance and this. of eourse, presupposed getting the tires

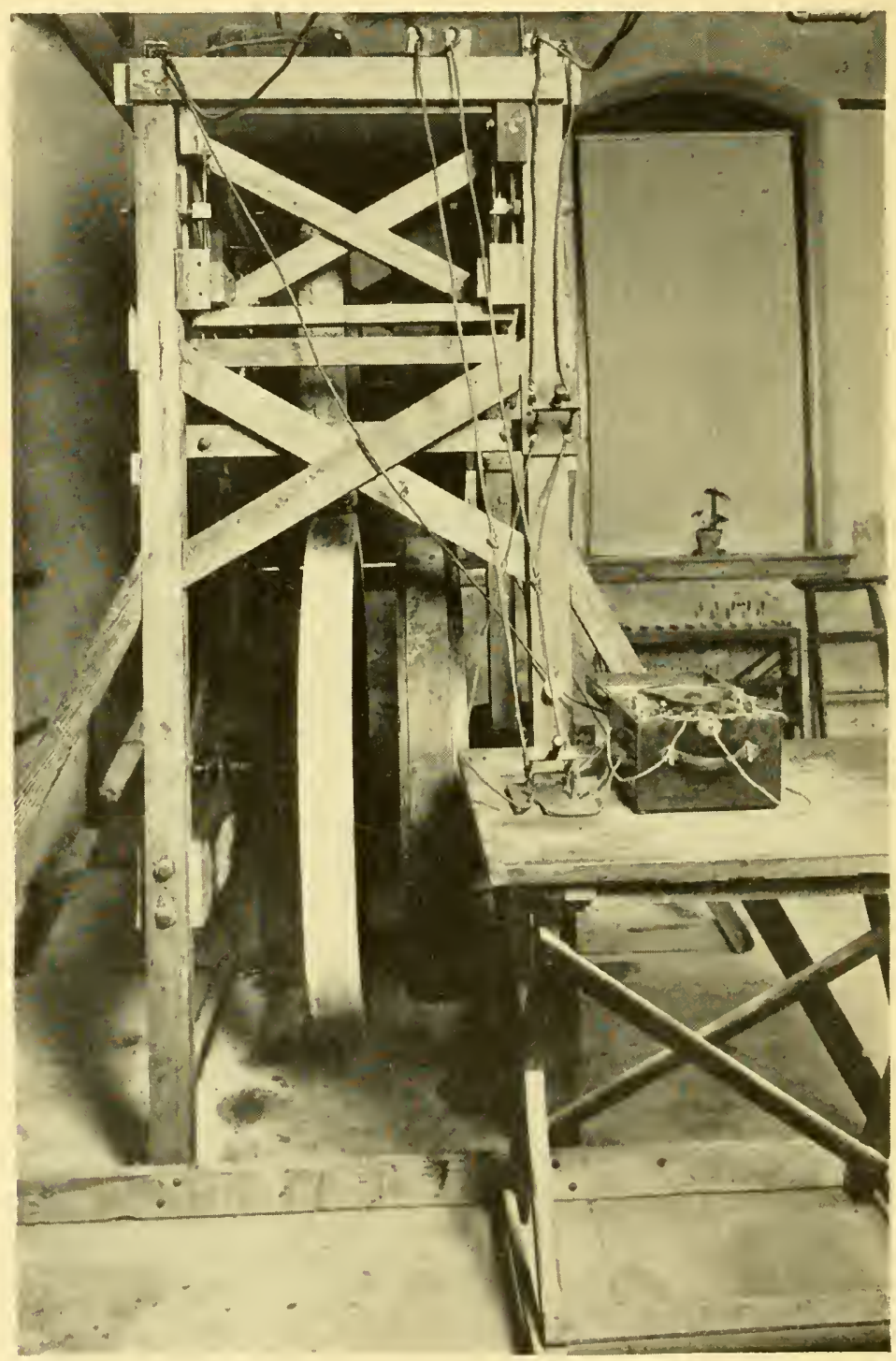

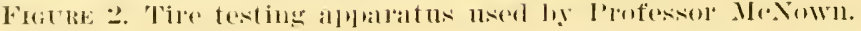

into a eondition of enstant weight in all robations execpt that of wear. sureh posed to be vely diflienlt-in faret. Wrate not get satisfied with 
our solution of this problem. Rubber tires, are more or less porous and readily gain or lose in weight by taking on or throwing off moisture. Within rertain limits. their weight fluctuates with the degree of humidity of the air. Table II gives the history of such variation for one tire through a period of two months.

An attempt was made to dry the tires to a constant temperature in a specially devised container heated by a Freas electric oren. Table II shows the degree of success attained. It also shows that as soon as the tires were remored from the dryer they began to increase in weight, due to an accession of moisture. Such absorption doubtless continued thronghout the twenty-hour period necessary to make a 500 -mile-tire-wear rum, affected of course both by the heating and the ventilating to which the tire was subjected during the run. The solution adopted was to take the tire from the dryer, expose it to the atmospheric condition of the room in which the test was to be made, ascertain its hourly rate of change in weight. and compute a correction.

Considerable thought and effort has been directed toward finding a moisture-proof coating to protect the tires. E. I. du Pont de Nemours \& Company has furnished such a coating in their Viscolac. This, however, is a celluloid lacquer and not very suitable for use on rubber. It has not yet been given a trial.

The laboratory test.- It is well known that traction is an important factor in the wear of the tires on the driving wheels. For that part of the work which is to be done with the ar on the varions roads the traction will be a variable. chiefly on account of the different grades encountered on the roads and the different tractive efforts required for different road surfaces. For this reasoli it was thought necessary to plan for the development of a "Wear-Traction" curve through the use of the laboratory apparatus and the wheel shod with concrete, and possibly with brick and asphalt as well. Such work as has been done this season has been on a concrete-shod wheel and at a traction of 50 pounds per ton. This value was taken simply to derelop one point on the curve.

In order to control the traction on the laboratory apparatus the efficiency curve of the upper or driving motor was determined; then the carriage was raised so that the anto wheel was clear of the road and the power necessary to run the auto wheel in this condition determined. Then the additional power needed to produce a given traction was computed and that traction maintained by the operator by the aid of the wattmeter and electrical resistance in the form of load racks, so called. 


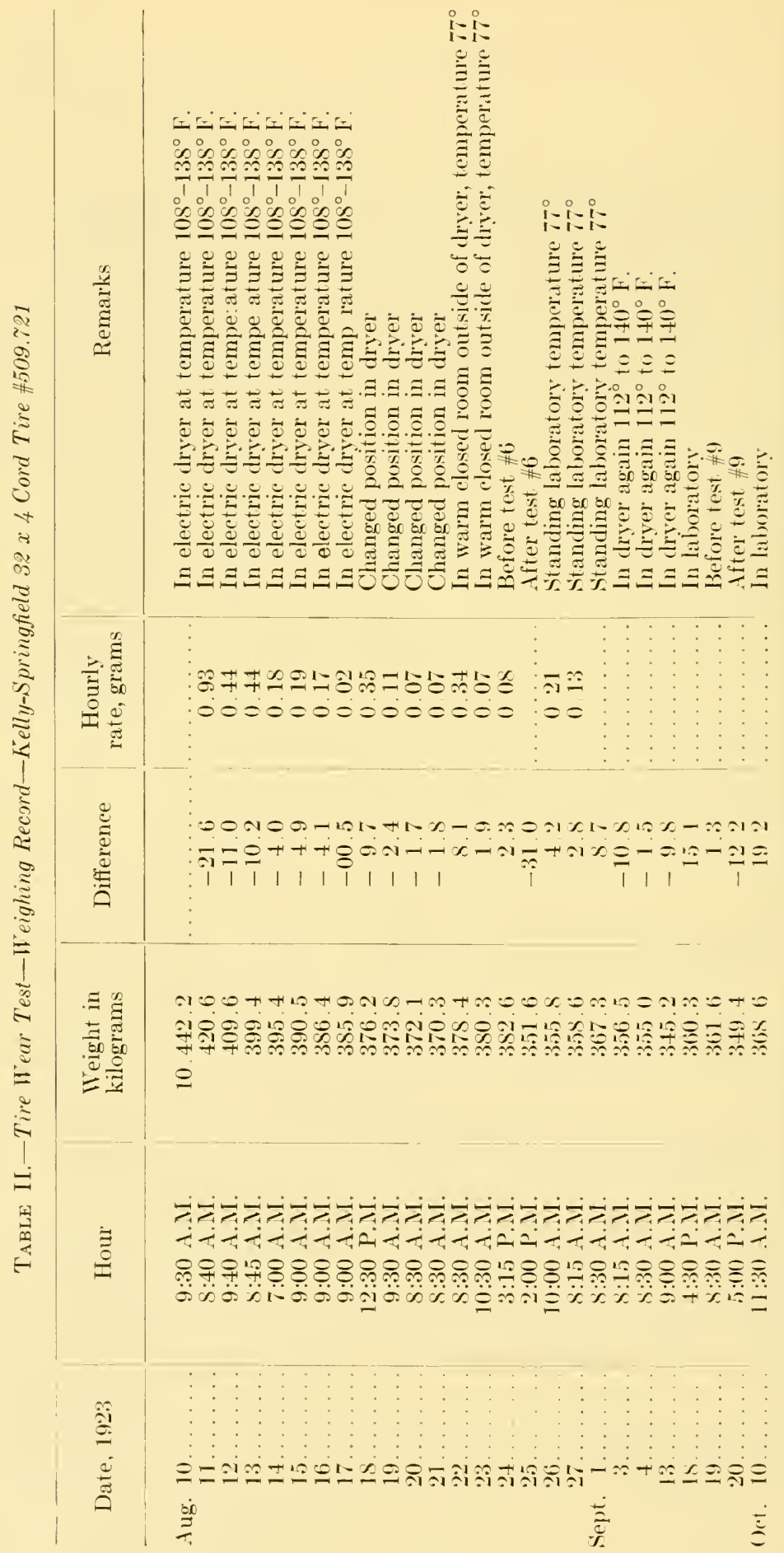


The inflation of tires was kept at the standard of the tire manufacturers, viz., 65 pounds.

Table III shows a typical set of running notes for one run of 500 miles.

Weighing the tires.-The weighing was done on an E. I. Sargent Company fine balance loaned by the Kansas Bureau of Weights and Measures, having a capacity of fiftr pounds and a sensitiveness of one-tenth gram.

The results of the laboratory tests. - Table IV shows the results so far attained.

It was in the search for the reason for the discrepaney in Test 2 that it was found necessary to give the tires a drying treatment. At the end of Test 4 the first concrete wheel developed a weakness and had to be discarded. The results of Tests 5, 6, and 8 are remarkably coneordant, considering that they were made on different tires. There is no explanation for the low value from T'est 7 . The purpose of Tests $5,6,7$ and $S$ was to prepare a set of tires to put on the ear for a road test. The car apparatus. however, developed a mechanical weakness which has taken weeks to correct, and hence the road running was postponed until next season. Had a road run been made, it would have been necessary to re-run with the tire used in Test 7 for a check upon the value obtained. The plan is to put all tires over the laboratory apparatus before they are used on the car. in order to develop any individual characteristics or weakness. How frequently this will have to be repeated cannot be decided until results begin to come in from the road-testing with the car.

Inside temperature of tires.-One by-product of this test may be the determination of the inside temperature of automobile tires. A device has been prepared whereby a thermometer may be inserted into the inside of the inner tube through an inlet similar to that used in inflating a tire. The thermometer is protected from the air pressure inside the tire by a thin brass wall. Inasmuch as it may be left in the tire indefinitely, it will soon come to the heated condition which will permit it to register the inside temperature of the tire. On account of the pressure of more important preparation, no results have been taken with this apparatus. It may, of course, be used either on the road or in the laboratory.

Equipment for testing tires on the road.-1 Dodge Bros. touring ear was chosen on account of its moderate cost and because it seemed to represent fairly well an average size. The one secured is of the late 1921 model, had been run about eighteen months, and was in good mechanical condition. The local dealer at Lawrence, through 


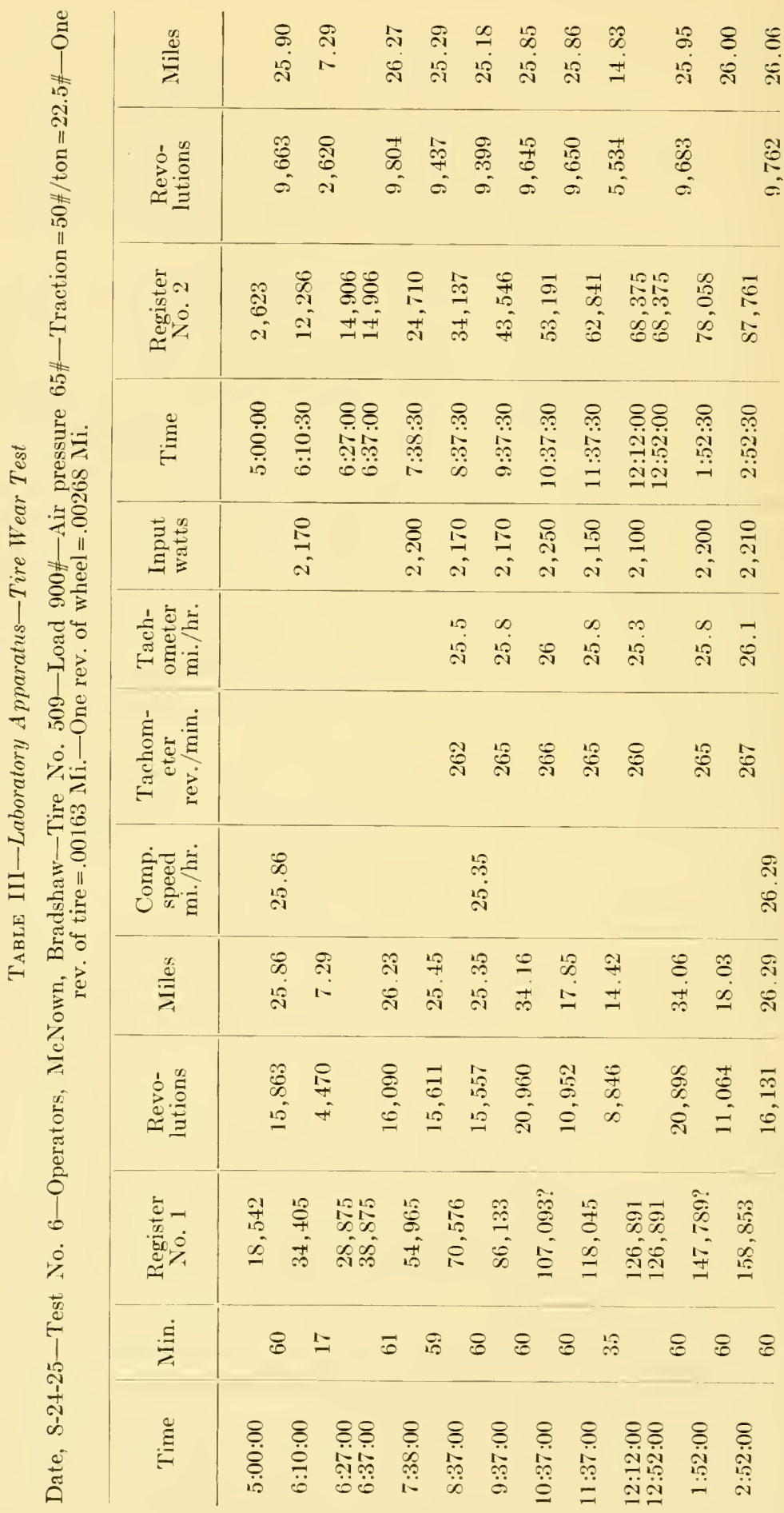




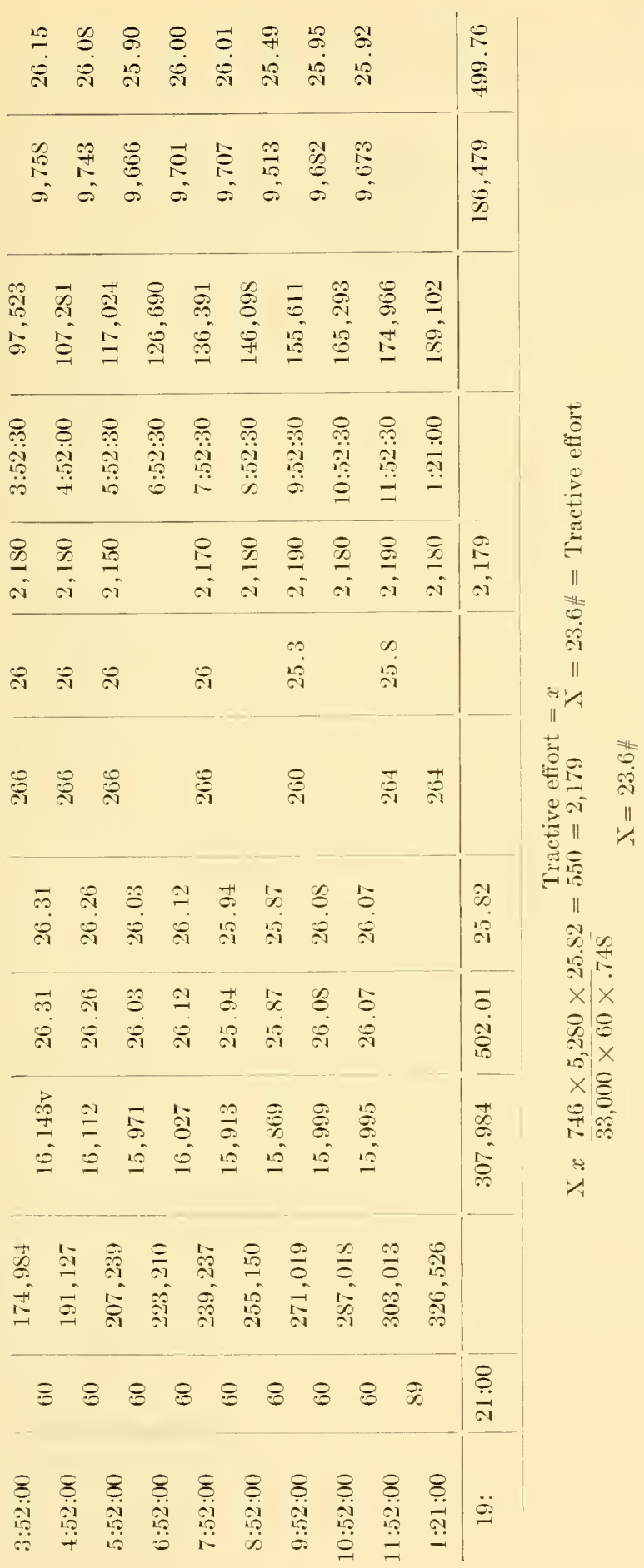


whom it was purchased, gave it a thorough overhauling. with especial attention to alignment of whecls and mechanical condition of steering gear.

TaвLE IV.-Results in Laboratory Tire Wear Apparatus

Loss in grams in a 500 -mile rum

\begin{tabular}{|c|c|c|c|c|c|}
\hline Test No. & Tire No. & $\begin{array}{l}\text { Loss } \\
\text { in } \\
\text { grams }\end{array}$ & $\begin{array}{l}\text { Cor- } \\
\text { rected }\end{array}$ & $\begin{array}{l}\text { Road } \\
\text { wheel }\end{array}$ & Remarks \\
\hline $\begin{array}{l}1 \\
2 \\
3 \\
4 \\
5 \\
5 \\
6 \\
7 \\
8 \\
9\end{array}$ & 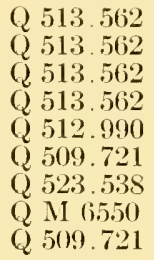 & $\begin{array}{rl}17 & 6 \\
6 & .0 \\
20 & .2 \\
24.2 \\
32 & 9 \\
31.0 \\
20.4 \\
31.2 \\
42.2\end{array}$ & $\begin{array}{cc}34 & 8 \\
32 & 0 \\
22 & 1 \\
32 & 9 \\
\ldots & \ldots\end{array}$ & $\begin{array}{l}\# 1 \\
\# 1 \\
\# 1 \\
\# 1 \\
\# 2 \\
\# 2 \\
\# 2 \\
\# 2 \\
\# 2\end{array}$ & $\begin{array}{l}\text { Not previously dried } \\
\text { Not previously dried } \\
\text { Not previously dried } \\
\text { Dried to a low hourly rate of loss } \\
\text { Dried to a low hourly rate of loss } \\
\text { Dried to a low hourly rate of loss } \\
\text { Dried to a low hourly rate of loss } \\
\text { Dried to a low hourly rate of loss } \\
\text { Brick shod wheel }\end{array}$ \\
\hline
\end{tabular}

* At the end of $14 t$ miles the lrick shod wheel developed weakness which required the discontinuance of the run. The loss in weight of 12.2 grams was raised by proportion to the 500-mile basis for comparison.

In order to neasure traction, the car had to be equipped with some form of dynamometer or torque meter, together with autographic register. Prof. A. H. Sluss. Director of Fowler Shops at the University of Kansas, was perfecting a torque meter, and after seeing it tried out, we decided to adapt it to our purpose. An autographic register suitable to our needs, and much less costly than any that could be purchased, was made in Fowler Shops. Figures 3,4 and 5 show the set-up of both torque meter and autographic register.

'To adapt the torque meter to the car. it was necesary to cut the propeller shaft and put flanges on the two ends thus exposed. The torque tube also had to be cut and bridged aromd the space to be ocempied by the torcute meter. Roller bearings were inserted between torque tube and propeller shaft near each end of the torque neter. A housing orer all to keep out dirt will probably be neederl.

The antographic register is driven from the propeller shaft by suitable gears and a flexible shafting. The paper speed is about trin inches to the mile. Pressures are transunted to the paper by a stean indicator gauge using a j0-pound spring. I elock-work. solenoid and pencil puts a mark on the paper at fiftecn-second intervals.

Calibation of the torque meter. - We a!r at present engaged in ealibrating the torque moter by the use of a l'rony brake. The ar 
is mounter on a platform and the two rear wheels run on two wheels at each end of the Prony brake-shaft, according to the usual set-up. The many delays incident to ironing out mechanical difficulties have

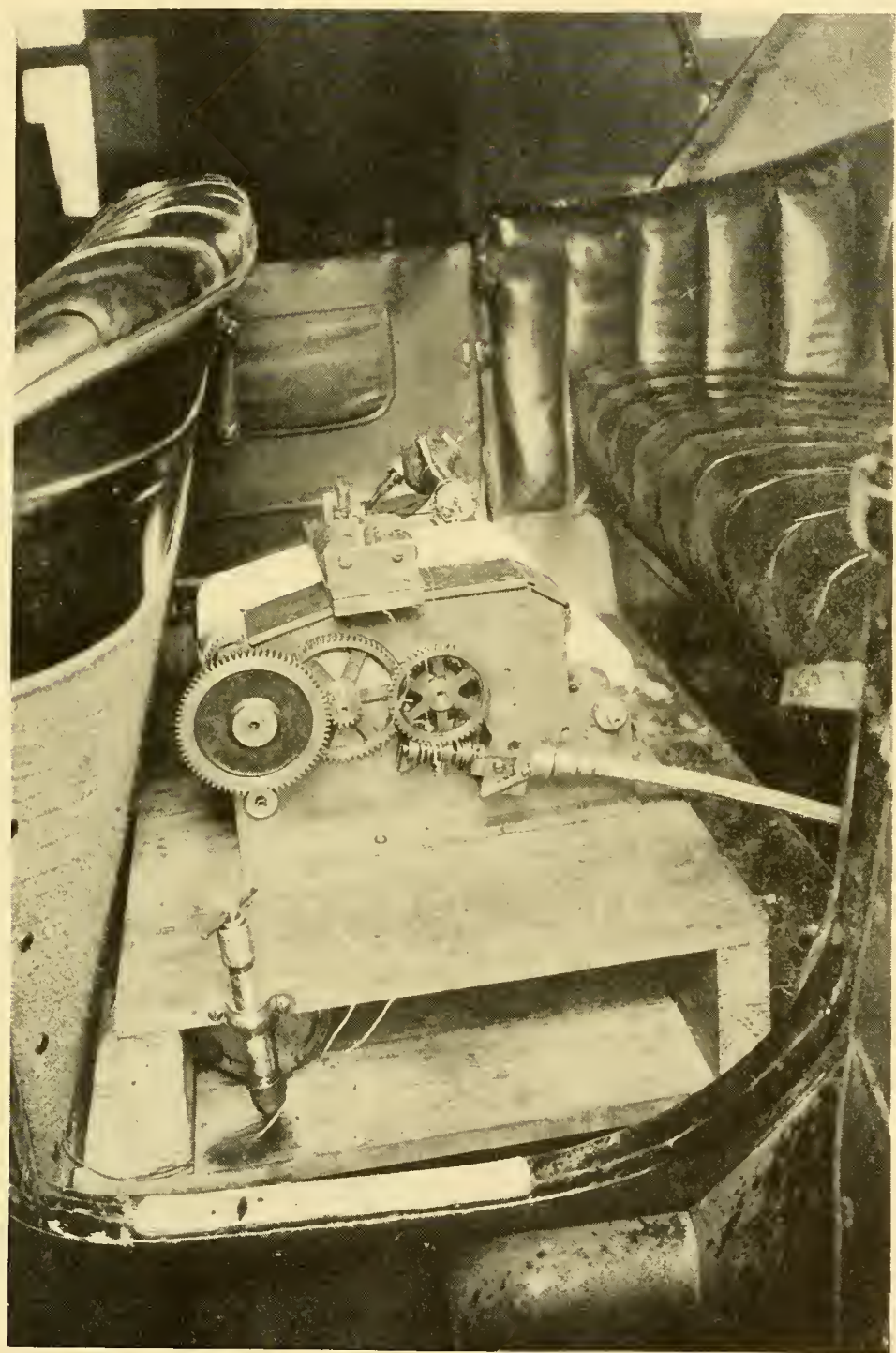

Figure 3. Torque meter.

so delayed this work of calibration that no results are available at this writing. It is hoped very soon to establish the relation between traction at the road and the ordinate of the indicator diagram. 


\section{No. 4. Cont of Operation of Motor Venholan}

a. Project organized hy American Automobile 1sociation. licport not get available.

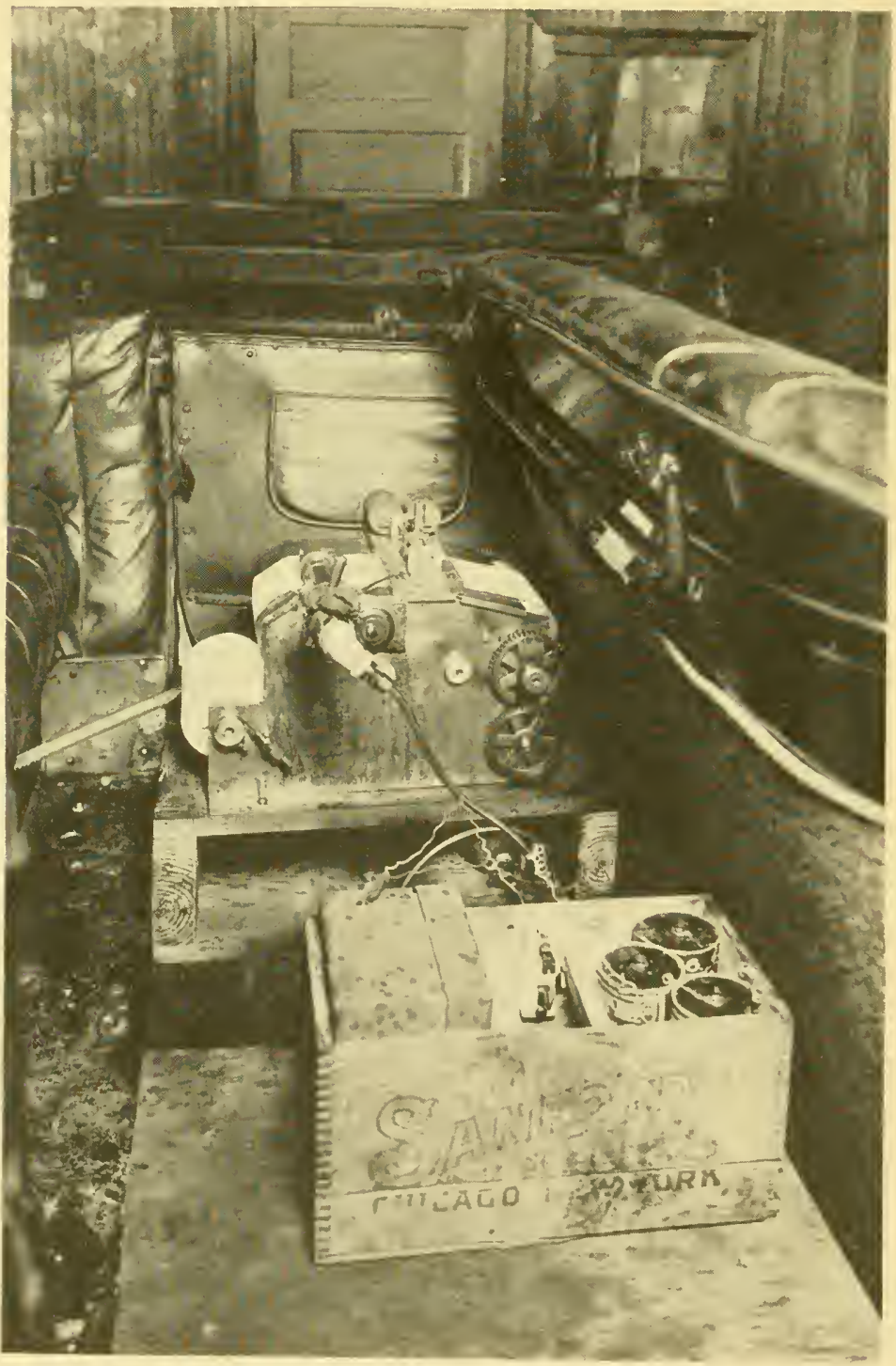

Figitie 4. Torpue motert.

b. I'roject organized hy Towa state College. 'This pujoet involves not only a sturly of the valuous items that enter inte the enst of 
vehicle opcration, but also a eorrelation of these costs with type and condition of highway. A small amount of work has already been done, but the project is praetieally a new one.

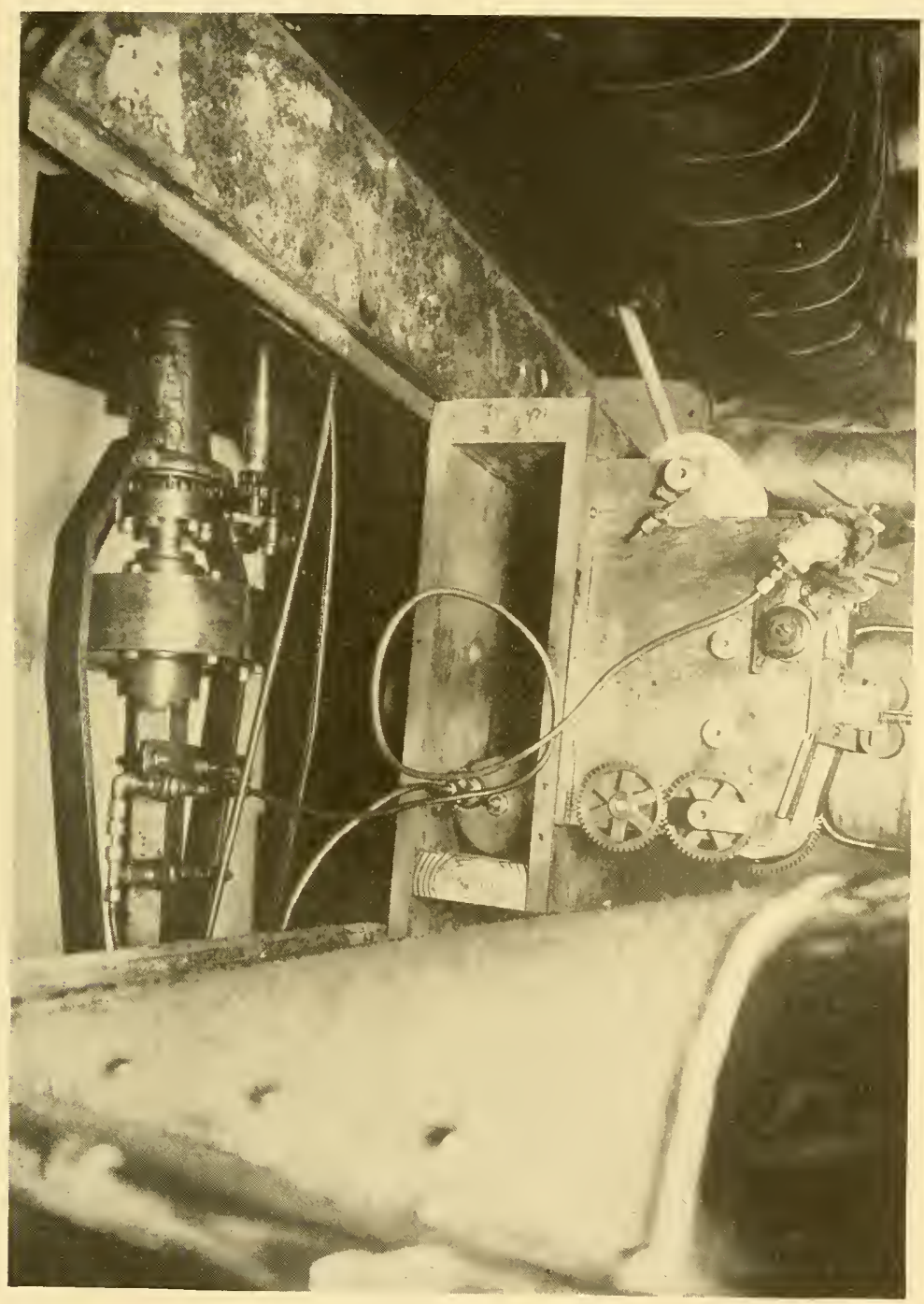

Figure 5. Torque meter.

No. 5. Roldixg Resistixen axi Related Cularacteristice of ROADWAY SLRFACES

It will be noted that a final report ha- leen marle on a project under this title. There remain a few factors of inmediate inpor- 
tance to he investigated, and this work is under way at Ines at the present time. The most important is the determination of the change in rolling resistance with the thrust (or tractive effort) of the driving wheels. In this work we are using the transmission dynamometer designed by Mr. Beebe, of the $U$. S. Burean of Public Roads, and I think that the desired information will be obtained shortly.

Prof. Agg: P'rof. Manly, have you anything to report this year"?

Prof. Manly: We are going on with the work on "The effect of tires and spring suspensioms on maintenance of rehicles and roarls" and attempting to develop reliable apparatus and methork of tests. The problem gets harder the further one advances. So far, I have no final results to report.

l'rof. Agr: 'This is typical of this kind of problem. We rork along for several years on a method of solving the problem. When methods are onee determined, results come quickly.

Chairman Johnson: Prof. Agg's report is before you for discussion. Are there any questions?

Chairman Johnson: What factors are to be taken into consileration in the evaluation of the roadbed of highways?

loof. Agg: That is a matter which we hope to take up at a future conmittee meeting - the question of exactly what factors should be included in the evaluation of the highway in the total cost of highway transportation. I have ventured to prepare a tabulation in which I have included the cost of the right of way, interest on eost of highway surface, cost of maintenance of right of way, eost of the roadway surface and maintenance of roadway surface; then the usual plan for an annuity whereby the cost of the roadway surface will be amortized at the end of the economic life of the roadway surface. These are items to be included in the cost of the highway itself and similar items for the vehicle. It is largely my own work and will be submitted to the eommittee hefore it is published as committee information. It seems logical to put in the cost of the right of way, but most people do not agree with ne on this point. I charge the number of acres per mile in the right of way at $\$ 2.50$ per acre, and it amonnts to about $\$ 2,000$ a mile.

Mr. shirley: I find the cost rums about $\$ 1.000$ a mile.

Mr. Manly: Do you allow for appreciation of value in the right of waly?

Chaiman .Johnson: Is it charged as an expenditure? The taxpayers having spent the money, should there he any further interest charec on money spent as cost of highway? 'There is no current charge in public ledgers. 
Prof. 1 gg: We charge interest every year on $\$ 2.000$ at 4 per cent as a capital charge for the right of way. There was no charge in the first instance for right of way taken from adjoining lands. Today we do pay hard money for it.

Chairman Johnson: How far back should we begin or cease to make charge for interest?

Prof. Agg: If the scheme of evaluation I mention is carried out, payment of interest will not cease as long as the highway is used.

Prof. Tilden: In the evaluation of $\$ 2,000$ a mile, what was the original investment in right of way?

Prof. Agg: The value of the right of way.

Prof. Tilden: Suppose at the present time there is traffic over the right of way of, say, 1,000 vehicles a day. When that increases to 10,000 vehicles a day, is there any change in the capital charge?

Prof. Agg: No.

Prof. Tilden: The value of that mile of right of way to the community has unquestionably increased.

Mr. Blair: The original investment in Iowa roads was practically nothing, and I am wondering if the use of the road or the use of the abutting lands has developed their present worth. Will Prof. Agg evaluate the right of way in accordance with the fluctuating prices of land?

Dean IIughes: Does Prof. Agg intend to readjust this value every year or so? I found the cost of Iowa land a few years ago was less than $\$ 50$ an acre.

Prof. Agg: I do hope to get a mit of cost for transportation per ton-mile on publie highwars of any type that will be applicable at the time it is published. Whether it will ke any good ten days after I cannot tell. It strikes me as being excecdingly important for the highway engineer to know what it costs hinı per ton-mile to transport over dirt roads, including cost accruing to the vehicle itself and to the road itself. When it has begun to cost him more to transport over a dirt road than over water-bound macadam, he should transform the road into water-bound macadam; and when it costs more to transport over bituminous macadam, he should put a high type parement on the roadway surface. Above 300 vehicles a day, earth roads can be replaced by paved roads and money saved.

The road costs are insignificant costs. It is the vehicle costs that count. So far as Iowa is concerned, the total cost of vehicle operation. including capital and operating costs, will be this year about $\$ 225,000,000$, and the total expenditure for new construction and for maintenance of highways will be $\$ 25,000.000$. inchuding every kind of highway. Vehicle costs entirely overshadow the road costs. 
Mr. Lemon: I should like to ask whether rate of tire wear is to be determined by tread wall or by carcass failure. Also, after completion of the rotating concrete wheel tests, are the results going to be comparable with road service tests?

Mr. MeNown: 'The scheme we are nsing for testing tires is to meastre the los liy wear from the trearl. We to not test carcass failure. That question has not been taken up. In measumg the wear, work has bean done in the laboratory, but nothing as ret on the road. Whether the work done in the laboratory will correlate with that of the road remains to be seen.

The report of Committee No. 1 was accepted.

Mr. IV. L. Ilolt, of the U. S. Bureau of Standards, presented a paper on

\section{RESEMRCH ON RUPBER TIRES}

The various departments of the government spend in the neighborhood of a half million dollars per year for premmatic tires. Inasmuch as these tires are purchased on a competitive basis, the setting of proper standards to be used as a basis of purchase is a rery important consideration. The U. S. Burean of Standards, in conjunction with the other interested departments and the tire manufacturers, has been instrumental in establishing a standard for purchases, and with the large rolume of business it will be seen that a small percentage increase or decrease in the purchase price, or in the quality, means a considerable amount in dollars and cents.

I an going to outline some of the work which has been carried on at the Bureau with a view to establishing a better basis for tire purchases. The present specifications, which have been in use for some time, although revised from time to time, cover detailed requirements in regard to the material to be used, including certain chemical and physical tests, and also preseribe methods for putting the tires together. While such specifications serve a useful purpose and aid in sorting out the good from the bad, they are not foolproof, as it is possible to build tires of the best of materials while the resulting product will not give satisfactory service. On the other hand, tires have been found eonstrueted of materials of mediocre quality which have yichled at least arrage service.

In an attempt to better such specifications a laboratory endurance testing machine has been installed. With this machine the tire is mounted on a wheel, free to revolve, which is carried on a novable carriage and pressed against a 5 -font flat-faced drum with a pressure corresponding to the axle load. The drum is driven at a surface speed of $30 \mathrm{~m} . \mathrm{p}$. h. and thus the tire is revolved and subjected to 
flexing such as it would receive on the road. Cleats are bolted across the surface of the drum at intervals so as to give the effect of bumps in addition to the flexing.

Contrary to what seems to be the popular idea, the problem in tire-building is not to make a tread which will wear, but to make a tire in which the component parts-the plies, the breaker, the tread, etc.-will stay together, and at the same time distribute the various strains so that the strain will not be excessive at any point. As soon as any of the parts separate, chafing immediately sets in, blisters begin to appear at various places, and the life of the tire is about gone. Accordingly, in developing such a test the motive has been to produce primarily a carcass test, the question of tread wear to be taken care of as a separate test.

It has been found that the conditions under which a tire is runthat is, the air pressure used, the axle load, and the nature of the cleats-have a marked effect upon the mileage which a tire will give on this machine. By changing these conditions, different features of a tire can be tested. For instance, a high air pressure and small cleats seem to yield a particularly severe action on the tread portion, and failure is apt to occur, due to tread separation, unless that particular feature is especially well designed. Larger cleats seem to cut down the mileage considerably and are especially severe on the carcass, so that failure is apt to occur, due to ply separation or breaking of the carcass. If a set of, say, ten different tires is run under each of the two different test conditions such as I have mentioned, the order in which the tires will line up with respect to mileage will probably be quite different.

Accordingly, the problem has been to so establish the test conditions that the method of failure will be the same as would result from average road service. As I have stated before, such a machine does not determine the wearing quality of the tread, but rather is designed to pick out any carcass weakness which may exist. It has also been the aim to set the test conditions so that a test can be run in the shortest possible time.

From the present results, it appears that it will be possible to determine whether or not there is any weakness in the tire in about 1.000 miles of running. This means that, by operating a machine day and night, a test could be completed in less than two days. The Rubber Association of America is actively cooperating with the Bureau in this work and it is anticipated that such a test will be adopted in the near future.

Aside from the value of such a test directly to the government in making purchases, the numerous requests which are received from 
manufacturers all orer the country show the need for such at standard test for the tire industry in general.

In conjunction with such tests as 1 have outlined, power-lose tests of pneumatic tires have been carried on for the past two years. Over 100 tires of various makes and of sizes ranging from $31 / 2$ to 5 inches have been tested. The equipment consists of two electric absorption Gynamometers. One was operated as a motor and carried on its shaft a wheel and the tire to be tested. and the other operated as a generator and earried on its shaft a smooth flat-faced drum. The motor is mounted on a morable carriage. the arrangement being such that the tire can be forced against the drum with a pressure corresponding to the axle load. In this way the tire and drum constitute a friction drive by means of which the motor drives the generator.

Aside from the tire itself, four principal variables enter into the determinations: speed, tractive effort, air pressure and axle load. The method of determining the power loss is to mount the tire on the wheel on the motor shaft and force it against the drum by means of weights acting through a bell-crank lever. The axle load is varied by changing the weights. The air pressure may be changed in the usual way. In onr case the tire can be inflated or deflated while ruming by means of a slip joint on the hub. This arrangement also aids in maintaining accurate pressures. Speed is taken calre of with a variable speed motor and the tractive effort by cutting ont generator resistance.

The power loss is the difference between the input to the tire by the motor and the output to the generator by the tire. It is measured by mechanical rather than electrical means, which elimimates the consideration of motor and generator efficiency, bearing friction. cte. Tests are made by rumning a tire undre varying conditions and mestring the energy input and output under each. The difterence between these figures after making a small correction for windage represents the loss in the tire. This loss is manifested by the gemeration of heat and a rise in the tire temperature.

Certain conchusons have been drawn as to the effect of arde of these variables.

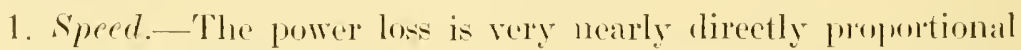
to the speed-that is, at $40 \mathrm{~m}$. p. h. the loss is approximately twice that at $20 \mathrm{~m}$. p. h. This means that the resistance which a tire offers to rolling. or what will he referred to at the rolling resistance, is very nearly constant and is independent of the speed. 
2. Axle load.-The axle load has a similar effect on the power loss unless excessive loads are used-that is, there is almost a direct proportion, and doubling the axle load doubles the loss.

3. Air pressure--No simple relation exist between air pressure and power loss; there is a rapid increase in power loss under low air pressures. Under high air pressures the loss approaches a constant value.

4. Tractice effort.-The introduction of a moderate tractive effort does not seem to have much effect on the power los. For instance, if the input to a tire is one horse-porrer, and the output zero horse-power, the los is one horse-power. If there is a five horse-power input, the output will be almost four horse-power. Under higher tractive efforts, the effect on the power lose is more marked.

Is a simple and quick means of comparing tires, the following were used: (1) Zero tractive effort. (2) The air pressure as recommended by the S. A. E. for the maximum recommended load. (3) The maximm recommended axle load for each particular size tire. the loss calculated as the rate per 1,000 pounds luad. (4) Expressing the loss as pounds rolling resistance per 1.000 pounds axle loarl. which eliminates the item of speed.

The following figures are a summary of the rolling resistance of different kinds of tires.

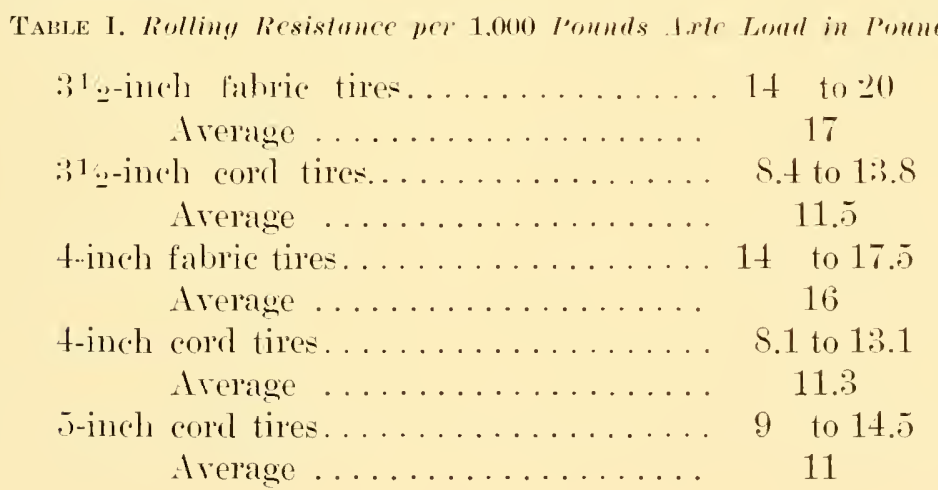

It will be noted that the arerage rolling resistance of cord tires. irrespective of the size, is a little over 11 pounds, while for fabric tires it lies between 16 and 17 pounds. This indicates that the performance of the different sizes of tires is about the same. In round numbers the rolling resistance of tires varies from $S$ to 20 pounds 
per 1,000 pounds load, with 14 as the dividing line between cords and fabrics.

At the present time fabric tires are rapidly becoming obsolete, except for the smaller sizes; but, taking the cord tires only, the one with the lowest rolling lesistance is only 56 per cent of that of the highest. The popular idea is that these differences are due to the design of the tread. This has some influence, but it is not the deciding factor. Taking wo tires, one with a smooth tread and one with a non-skid or bumpy tread, it is not possible to tell from ontside appearance which will offer the most rolling resistance, although, other things being equal. the non-skid type of tile will probably show a slightly greater resistance. The real cause for differences lies in the carcass construction. While from appearances the two carcasses may be identical, small differences in the rubber compound, the lay of the cords. the amount of rubber, ete., will materially change the internal friction, and hence the rolling resistance. The fact that the carcass construction is the deciling factor is brought out by the differences between cord and falmic tires. It also emphasizes the statement made in the first part of this paper, that the problem in tire design is not to make a tread that will wear, but to make a tire that will hold together with strains reduced to a minimum.

As a check on laboratory figures, the losses in several sets of tires have been determined in the laboratory and then the same sets put on an automobile one after the other and the difference in the rolling resistance determined hy towing behind another car. This test was carried out at various speeds and under diflerent inflation presures for each set of tires. While the results have not been completely compiled as yet, the differences in rolling resistance were apparent at once and the results seem to follow chosly the laboratory determinations.

As to the significance which may be attached to such figures, the first thing which eomes to mind is the effect on fuel consumption. Comparing the effect of a change in tire couipment on furel consumption is simply a matter of measuring the loss in each case and finding the fuel nerestry to generate the axcess power. The difficulty of making an accurate statement as to what this difference will amount to is the lig rariation in fuel required per horse-power, not only in different engines, but in the sance engine run under different conditions. Work is being earried on at the present time to make determinations such that some fair average values may be given.

$\Lambda$ second value which may he attached to power loss determinations is their use by the tire designer to analyzo the influence of details in 
the tire construction. By hhis means it should be possible more closely to coordinate the different parts and reduce friction or wasted energy to a minimum, and at the same time prolong tire life. These investigations are heing extended to solid and cushion tires. The latter tires in particular are coming quite into prominence at the present time, with many new kinds being put upon the market. The balloon, or air-cushion type, is also being taken up, but not enough rata is ret available to draw any definite conclusions as to how the power loss compares with that of the wanal type of tire. From the standpoint of absorling lumps, there is no question but that balloon tiles are superior.

In connection with reclaimed rubler, the we of a larger percentage in tire treads is being investigated. One lumdred tires have been built, the tread of each consisting of sections containing ditferent combinations of new and reclained rubber; these are being tested on post-office cars run over loals selected with a view to giving as many rarieties of road wear as possible. In addition to the direct conchsions which may he obtained from these tests, an opportunity is afforded for obtaining some data as to the value of the various types of laboratory abrasion machines in nee. Aecordingly, a complete study is being marle on the rubber compounds used in the treads, using as many types of aluasion testing machines as possible. These results in comnertion with the roar tests should give valuable information for interpreting the results of laboratory tests.

Mr. Crane: IIas there heen enough work aceonplished in the way of results to conncet in any way the rolling resistance with tire life? Is there any inclication that the tire with the least rolling resistance has longer life"

Mr. Holt: In that connection what is measured is the total energy lost in the tire which is made up of the sum of the loses in the unit parts. There may be a small part of a tire in which there is a high unit strain which would not show up as excessive compared with the total loss. and until such an be differentiated the tire with the lowest total loss will not necesarily show the greatest road mileage.

Prof. E. H. Lockwoor, of Yale L'niversity. (*ontributed the following description of a road seismograph for motor rohicles.

\section{ROAD SEISIOOGRI'H FUR MU'TOR VEHICIES}

This instrmuent was rerised originally in an attempt to measure the value of shock alsorlocrs. snubbers, ete. as applied to motor vehicles. It proved useful for the purpose mentioned, and since has found applications in measuring the relative roughness of different 
stretches of road, the riding qualities of different vehicles over the same road, and the effect of tire inflation and the so-called balloon tires.

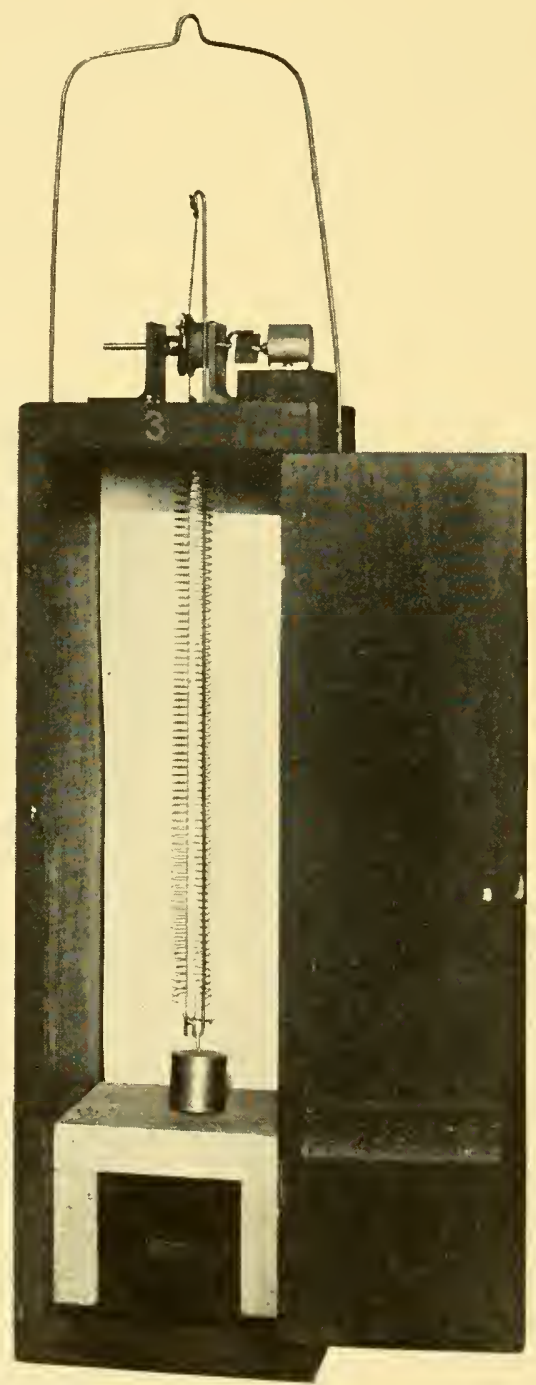

Figure 1. Lockwood road seismograph.

A photograph of the instrument shown in Figure 1 contains the usual suspended pendulum, with an attached mechanism for recording the relative motion between the pendulum and supporting frame in a vertical direction only. The recording device consists of 
a reciprocating spool, actuated by a linen cord wrapped around the spool, and tied to the ends of a light vertical rod which forms part of the pendulum. A friction ratchet transfers the motion of the reciprocating spool, in one direction only, to a revolution counter, which therefore integrates the reciprocating motion by reading on the dial. In the instrument shown in Figure 1, the spool was made about 13-16 inch in diameter, giving a register of one revolution for about 2.6 inches rertical motion. In using an instrument of this type the counter is read at certain stations, or distances, by the speedometer, and comparisons can be made directly from the counter readings as an index of the vertical shaking.

One feature of the instrument deserves special mention because it is not a part of the usual seismograph. This feature is a supporting table under the pendulum, whose object is to prevent the periodic

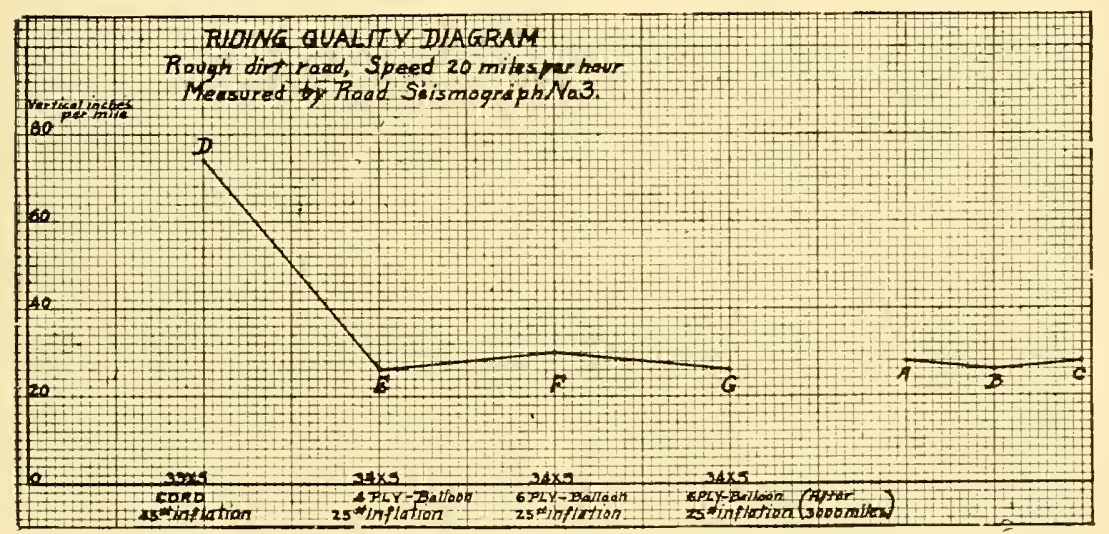

Figure 2. Record obtained by Lockwood road seismograph.

vertical oscillation of a free pendulum when carried on a vehicle. The motion of the supported pendulum cousists of a rebound or jump from the table, of height dependent on the intensity of the shock. The motions of the pendulum may be quite small and frequent. In actual use the counter will read steadily, with no visible motion of the pendulum. The sensitiveness of the instrument to small shocks depends on the location of the table. In the instrument described, the table supported about 2 per cent of the pendulum weight, and as thus constructed will not register on a railway coach over a good roadbed, but will give a considerable reading with any automobile over the smoothest road.

An application of this seismograph to velricle measurement is given in Figure 2. Tests $A, B, C$ refer to the riding quality of three 


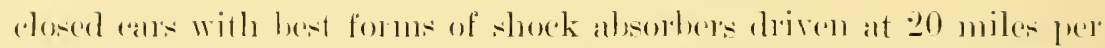
hom ored a rough dirt reat. Test D gives a similar record of a heary

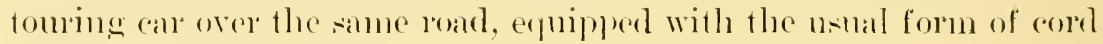
tires. Test E show the effect on war D of alphlying ballown tires with low inflation presire. Tests F and (i) are for othere forms of balloon tires, showing that diflerent forme of ballown tires are about on a par for riding qualities. This diagran suggests some nseful and pratetieal applieations that may be made of a simple instrumente of this kind.

Mr. Wr. S. Janes of the L. S. Burean of Standands, gare an illustrated discusion on "Texts of Braking and Stoplping Conditions of Motor Vehieles." This is not ret avalable for publiention.

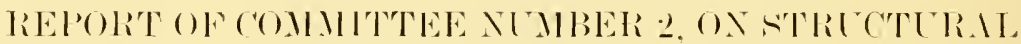 DEFIGN (OF RO.MTS}

The following repent is divided into two main portions: first, that dealing with the facts that have been brought out by researehes. and.

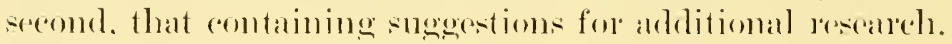

\section{I'MR'T I}

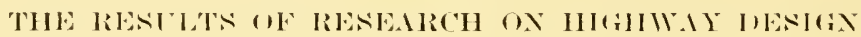

(a) Silitili.tIL

Research work on the subgrade seens to have been moler way ly the State Highway Commision of North Carolina. the Department of Public Works and Buildings of lllinois. Iowa state College, American Society of Civil Engineers' Committee on Braring Power of Soils, Ohio State Universty, and the C. S. Burean of Publie Roads. University of 'Texas and Mirhigan Agrieultural college Experiumt Station.

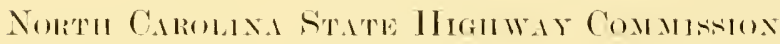

The work of North Carolina is presented in a report. entitled "Summiry of Results of Capillary Moisture Tests." ly H. F. Janda. Iniversity of Noth Carolina. Chapel Hill. N. C.

liesults: Briefty, the results indieate the efficioney of porous layers. such as sand. anders. broken stone, ete. in puesenting capillary moist ure from rising in to the orerlying soil. It is likewite stated that tile drains are found to be ineffiedent in remering calpillany moisture. 


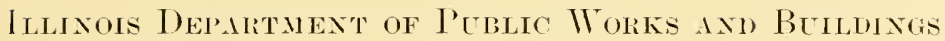

1 series of soil tests is under way, but no reports have been made upon them to date. New apparatus has been devised for testing soils under many subgrade conditions, including a new slaking test and a new method for making soil eylinders. Soil samples have been transplanted into the ground near the laboratory, in order that they might aequire their natural condition after having heen distubed.

Results: None reported.

\section{IOWA STATE COLLEGE}

Soil investigations have been earried on at Iowa State College sinee the smmmer of 1921. No published report has heen made to date. The first year's work was reported to the sreeial eommittee of the American society of Civil Engineers on the Bearing Value of Foils for Foundation. ${ }^{1}$

This investigation hats the following aims:

The determination of the rarious phrsical properties of soils in their modistubed sate as found in natme, such properties as the tensile, compresive. Sharing. transverse and other strengths. these to be determined mon vanions soils and at various depths and moler various conditions.

supplenentary tosts. such as true and aplarent specifie sravities, specific weights. capillarity. hysuresopic moistme. porosilies, mechanical analyses. coeffieients of friction, ete.

('hemical analyses.

Colloidality of clay.

To determine the laws of variation of presture in earths under various loads and under differing sasonal eonrlitions.

Results: Temsile tests gave an average value of 211.5 pounds per square foot for yellow elay and 2.5.0 pounds for blue clay. Tests were made on sections of two square feet area.

shearing tests gave vahues averaging 312 pounds per squale foot for sandy loam, ist pomnds per square foot for yellow clay. and $\$ 20$ pounds per square foot for blue clay. Test pieces had a square feet cross-section.

Compression tests were made upon picces from 6 inches to 9 inches in diameter by 6.5 inches to $14 . \bar{j}$ inclies long.

$\begin{array}{cc}\text { Lus. persq. in. } & \text { Trons persq.ft. } \\ 28.5 & 2.0 \mathrm{~s} \\ 17.2 & 1.24\end{array}$

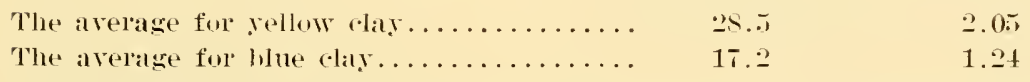

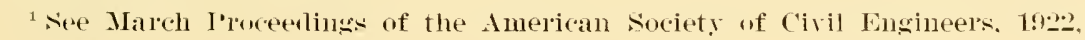
palge $5 \pi \pi$. 
Some four tests, given in detail, appear to show that soils, or these two clays at least, have a slight elasticity and do recover shape to a small degree after removal of load.

No reports of the work of 1922 and 192 s are available.

\section{A. S. C. E. Commettee on Bearing Power of Soíls}

The Special Committee on Bearing Power of Soils of the American Society of Civil Engineer's have gathered from various sources excellent information upon colloids in clays.

According to Searle, clay contains (1) colloidal silica, (2) colloidal alumina, (3) colloidal ferric hydroxide, and (4) possibly colloidal organic matter or humus. These colloids may modify the characteristic properties of elay, but Searle thinks those characteristic properties are not due to colloids. Van Bemmelin found that the fine suspensions of clay in water could be easily precipitated by adding a small quantity of acid, salt or alkali to the cloudy suspension.

In summarizing the discussion on colloids, the conclusion seemed to be that colloids are suspensions of very fine particles, as follows:

Suspensions-Particles over 0.1 micron in mean diameter.

Colloidal solutions-Particles between 0.1 and 0.001 micron in mean diameter.

True solutions-Particles under 0.001 micron in mean diameter.

The statement was made that the proportion of colloids that can be definitely separated from clays is less than 3.0 per cent.

Some properties of elay most satisfactorily explained by assuming the presence of colloids are:

1. The ratio of water absorbed to the plasticity.

2. The hygroseopic quality of clay.

3. The slaking ratio.

4. That to a certain extent pressure plays the same part as water in certain elays in produeing plasticity.

5. That clays are remarkably sensitive to the action of electrolytes.

6. The swelling and shrinkage of clays under increase or decrease of water content.

Rohland suggests that this power of imbibing a definite quantity of water is due to the colloirds in the clay, and that as soon as the clay 
has absorbed sufficient water to convert its colloids into a colloidal sol, its saturation point has been reached.

Mellor, Green and Baugh have analyzed the substances likely to be present in or to be added to clays into five groups, according to their action on the viscosity of the clay. They are as follows:

1. Substances which first make the slip more fluid, while further additions stiffen the slip: sodium and potassium carbonates.

2. Small amounts thicken the slip; larger amounts make the slip more fluid: dilute ammonia, copper sulphate, etc.

3. Substances which make the slip thinner: magnesium, sodium sulphate, etc.

4. Substances which only stiffen the slip: grape sugar, humic acid, ammonium chloride, calcium chloride.

5. Substances which have no appreciable effect on slip: alcohol.

Note, then, that the plasticity of clay may be reduced by adding such substances as ammonia, caustic soda, caustic potash, lime, sodium carbonate, borax and water glass.

Ashley and Rohland conclude that the plasticity of clay is directly proportional to the amounts of colloids that they contain.

The final conclusion of the committee is:

"It seems evident, therefore, that ultra clay is the principal binding material of the soil, giving it plasticity, cohesiveness, or hardness, according to the moisture content. The recognition of these important properties shows the fundamental relation the material bears to certain enginecring problems, including subgrades in road construction."

Note.-The Committee on Structural Design of Roads feels that further research is necessary on the effect of mechanical properties of soils duc to colloids before a definite conclusion can be drawn.

\section{Ohio State University}

The Ohio State University reports data on thirteen clays from ten different counties in the state. These are given in the following table.

One of the promising series of investigations was made upon impact upon subsoils.

Four shapes of impact heads were used, with the idea of selecting one that would give results the most uniform and the easiest to measure the deformation of accurately. This impact test would then be 


\begin{tabular}{|c|c|c|}
\hline & 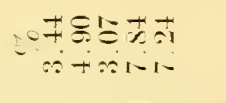 & 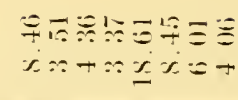 \\
\hline 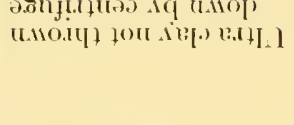 & 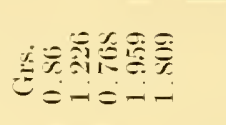 & 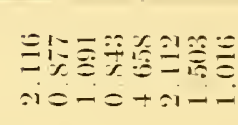 \\
\hline 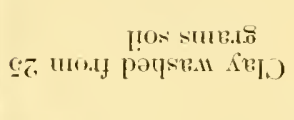 & 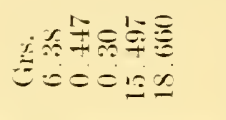 & 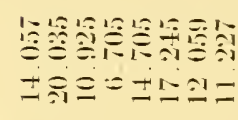 \\
\hline 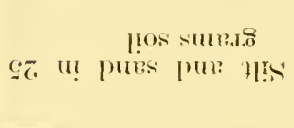 & 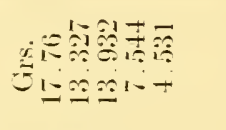 & 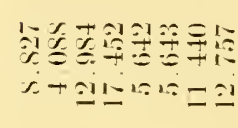 \\
\hline 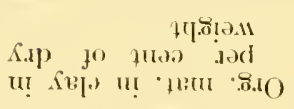 & $\begin{array}{l}+1+0+ \\
000 x+\end{array}$ & 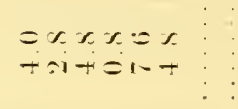 \\
\hline 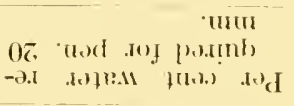 & $7 \div 8 \div$ & 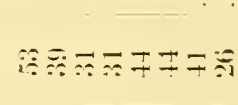 \\
\hline 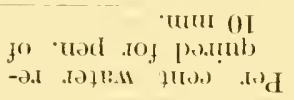 & 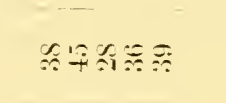 & 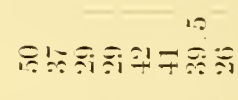 \\
\hline 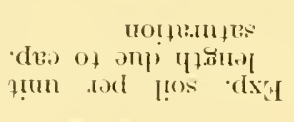 & 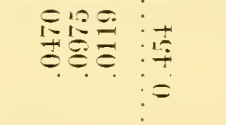 & $\begin{array}{l}0: 0) \\
=00 \\
0=0: 0:=0\end{array}$ \\
\hline 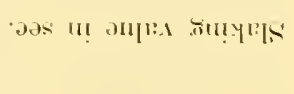 & 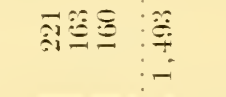 & 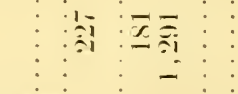 \\
\hline 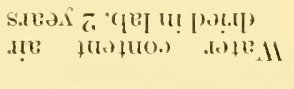 & $\begin{array}{l}910904 \\
0100101-1\end{array}$ & 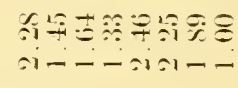 \\
\hline 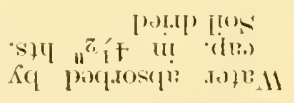 & $\begin{array}{l}0,11-1=0 \\
-8-5 x \leq\end{array}$ & 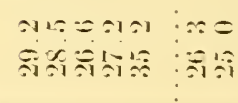 \\
\hline 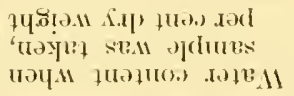 & 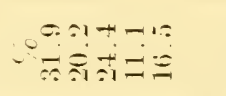 & 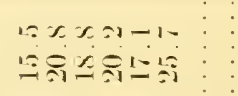 \\
\hline 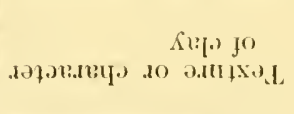 & $\vdots \vdots \vdots \vdots \vdots=\frac{3}{3}=\frac{3}{3}$ & 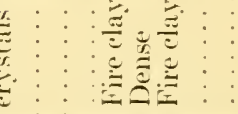 \\
\hline Se[י & 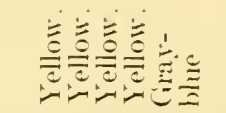 & 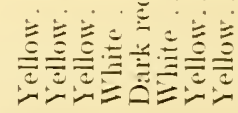 \\
\hline 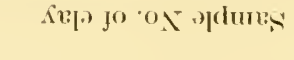 & 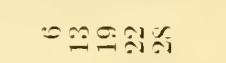 & לڤ \\
\hline
\end{tabular}


calibrated against static bearing power tests. and when ealibrated could be used in lieu of the static test, the adrantage being in the ease and celerity with which an impact test may be carried on.

The shapes used were:

1. The cireular flat head similar to the ones used by the U.S. Bureau of Public Roads.

2. A flat cone 30 degrees with the horizontal.

3. A truncated cone 60 degrees with the horizontal. with a flat face $2 \frac{1}{4}$ inches in diameter.

4. A segment of a sphere.

So far as tests have gone, numbers 2 and $B$ seem to give the most even results and fulfil the requirements as to meaturing deformations. No calibration tests have yet been marle.

\section{S. Bureat OF l'T'blat Ronts}

The U. S. Bureau of Public Roads test- aim:

1. It standardization of physical tests for subgrarle material.

2. At determination of efficieney of admixtmes.

3. At standardization of tests to determine the laws of moisture in the subgrade.

Physical properties of subgrade suits.-It is thonght that the tests in the laboratory for determining the phrsical roperties of subgrade soils have now been standardized reasomably well, with the possible exception of the bearing value test. These tests are disensed in a paper by .J. R. Boyd. ${ }^{1}$

In addition to the laboratory tests for the bearing value of subgrade materials, a field test has been devisen and is deseribed in the recent bulletin on Highway Research Equipment issued by the National Rescarch Comncil."

Field test for moisture equivalent.-Ittention should also be called to a field test for moisture equivalent which gives results rery closely cheeking with laboratory lesults and with very simple apparatus. This test was devised by Mr. A. C. Iiose, highway engineer of the U. S. Bureau of Public Roads. It is described by Mr. Rose as follows:

Procedure: I 300 -gram sample of soil is dried at $105^{\circ}$ centigrade and prepared in an iron mortar (when no harl rubler is available) to pass a 1-millimeter sereen. A 50 -gram sample of this is placed in

"Physical Properties of Subgrade Materials." See Iroceelings of A. S. T. M., 1922, Vol. 22 , pp. $344-347$.

${ }^{2}$ National Research Council Fulletin No. 3.). "Apparatus used in Highway Research Projects in the Tnited States." C. I. Mogentogler. 
a steel bowl. Water is added in small quantities from a burette and a tablespoon is used to mix the water and the soil sample. Care is taken to break up all of the lumps that develop. Water is added until the sample becomes uniformly of the consistency of putty and can just be compacted by the spoon without any free water appearing on the surface.

The moisture equivalent equals (the weight of water added divided by the dry weight of the soil) $\mathrm{x} 100$ plus 0.8 .

$A$ check rum is made and the average of the two used as the final result.

This test was made on 29 samples of soil taken from Oregon Federal Aid Project No. 51. Portions of the same sample were taken to the Oregon Agricultural College and the moisture equivalent was determined in a centrifuge (1,000 times the force of gravity) by the standard method. Results obtained by the use of the field method outlined above were found to compare very favorably with laboratory results when the constant of 0.8 was arlded.

It has been stated by Mr. Rose that the moisture equivalent value of twenty is somewhere near the dividing line between a poor and good subgrade. This is probably approximately correet, judging from the results of the analyses of a large number of samples of the Bureau of Public Roads Laboratory, but needs further verification.

Effect of admixtures upon some of the physical properties of subgrade soils.-In many sections of country the subgrade materials are of a very plastic nature, and when road surfaces are built on such subgrades the inadequacy of the subgrade must be compensated for either by thickened design or possibly by altcration of the subgrade material, which will change a soil of plastic nature into one having more granular characteristies and higher supporting value. It was with this idea in mind that the following investigation was undertaken :

In this investigation a soil was treated in the laboratory with Portland cement, high ealeium and high magnesium hydrated lime. In each case 5 per cent of the aforementioned adulterants was thoroughly mixed with the soil.

Upon each treated sample the capillary moisture test, the rolume test under eapillary moisture eonditions, and the bearing value test under capillary moisture conditions were made. The results of these tests are shown in Chart I.

The conclusions obtained from this chart are as follows:

1. The ardition of 5 per cent of high calcium and high magnesium hydrated lime increased the eapillary moisture of the soil 
about 4 per eent, whereas the addition of 5 per eent of Portland cement deereased the eapillary moisture about 1 per cent.

2. In spite of the slight increase in capillary moisture of the two lime-treated samples, the per cent of volumetric change of these two samples was very much lower than that of the untreated soils (about 10 per cent). The same phenomena took place in the ease of the Portland eement treated samples.

3 . The bearing value of the three treated samples was materially increased over that of the untreated soil. Admixtures of sand and other granular materials aeeomplish similar results.

Therefore it may be said that, from a purely laboratory point of view, the physical properties of a soil ean be materially improved by the addition of hydrated lime or Portland eement and granular materials. Further researeh looking into the eeonomy of this proeedure should be brought about.

The effect of heat treatment upon the physical properties of subgrade soils.--In this investigation two different soils were heated at temperatures varying from $200^{\circ}$ centigracie to $600^{\circ}$ eentigrade in steps of $100^{\circ}$ centigrade. On the soil resulting from each heat treatment the mechanical analysis, volumetrie ehange under eapillary moisture eonditions, and adsorption number were determined. The results of this investigation are shown on Chart II.

The conelusions may be stated briefly as follows:

1. A temperature of $600^{\circ}$ centigrade seems to be necessary to materially ehange the above-mentioned physical properties of the soils treated.

2. If this temperature is used, the meehanieal analysis of the soil is materially ehanged, in that the elay content is decreased and the sand eontent inereased.

3. The adsorption number (eharacter of elay) is decidedly decreased, produeing a much less active material.

4. The volumetrie contraetion was deeidedly deereased.

It may therefore be said that heat-treating a soil at a temperature of $600^{\circ}$ centigrade materially improves the physieal properties of the soil, but the cost of this process seems to be prohibitive.

Status of drainage and moisture in the subgrade.-Experiments on drainage and waterproofing road subgrades were begun during the summer of 1920 at the Arlington Experiment Station for the purpose of determining, if possible, suitable methods whieh would promote dryness and stability in this part of the roadway. Both lateral and transverse ditehes were cut to a depth of 30 inches below the center line of the finished pavement and kept open during the first winter. 
later. these ditches were obstructed and water allowed to stand in

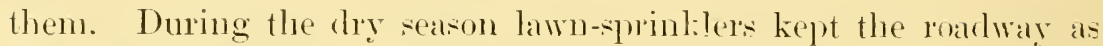
wet as it was possible to make it.

Results: J)uring the winter months and expecially near the alpproach of spring. all of the sections contained rather high percentages of moisture in the subgrade. In some ea-es the attempts to waterproof, especially by impervious walls, seemed to trap water under the pavement rather than keep it ont. Tile drainage did not in this cance decrease the amomit of water. except at a depth level with the drain. It that depth the decrease was only about 1 fer cent. It seems, then. that drainage of the types ned was only eftective in removing water in excess of the capillary moisture.

The maximum upward movement of the parement was approximately three-quarters of an inch, which ocenred at the time when there was the greatent rolume of moisture in the sulgrade. This was at a time when there was the greatest depth of freezing. The minimum movenent at this time was moler the seotim having the greatest depth of gravel base.

Influence of vibution: Experiments of this solt were bate on a 4 feet $x+$ feet concrete slab, with free water standing at $1 \cdot 2$-inch and b-inch depths below the subgrade. For the purpose of permitting the water to have eavier aleess to the subgrade immediately moler the parement, t-inch pipes were laid all around the slab at a depth of 18 inches under the sulgerate.

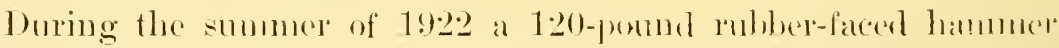
was allowed to ponmel almost continuons y on the parenent after the sulgrade had reached its maximum nosisture content hy capillarity, but there was no pereeptible increase in moisture due to vibration. These experiments will be repeated moder heary pursures.

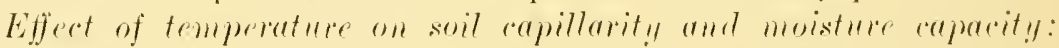
There is every evidence to show that temperature lass at rery marked influence on the water calpacity of soils. The eolder the soils. the greater the eapacity for holding moisture. Dr. Bonyoneus, of the Miehigan Agricultural Experiment Station. has done unteld work in this field, and his results have been checked at the Arlington Experiment Station. These effects are very clearly shown in Figmres 1 and 2, which ane typieal of conditions in many other whate and rurves on file in the Burean of Publie Romets.

From many examples arailable with shallow depthe of frost. it is roughly true that frost action affects moisture content at alproximately twiee the depth of the freezing. There is an increase in moisture in the frozen atath and a decreatse in the soil just betew the 
frozen section. This is due to the cold soil having a stronger capillary pull than the moisture-retaining power of the warmer soil.

The following figures show typical eapillary moistures for soils indicated at temperatures of from 0 to $5^{\circ}$ centigrate and from 25 to :30 $0^{\circ}$ centigrade.

Soil No. Temperature, $0.7^{\circ} \mathrm{C}$. Temperature, 25:30 C. Difference

$\begin{array}{cccc} & \text { Pescent } & \text { Percent } & \text { Percent } \\ 20 & 29.2 & 25.5 & 3.4 \\ 4 t & 34.5 & 29.7 & 4.8 \\ 61 & 36.6 & 92.6 & 4.0 \\ 7 t & 43.6 & 37.7 & 5.9 \\ \text { Ottawa } & 25.8 & 26.1 & -0.3\end{array}$

by comparing the eurves on Figure 7 , il will be observed that much greater differences than these are fomd under actual field conditions.

Influence of the quality of soil particles m moisture content, bearing value, etc.: This influence is particularly well indicated in

Figitre 1
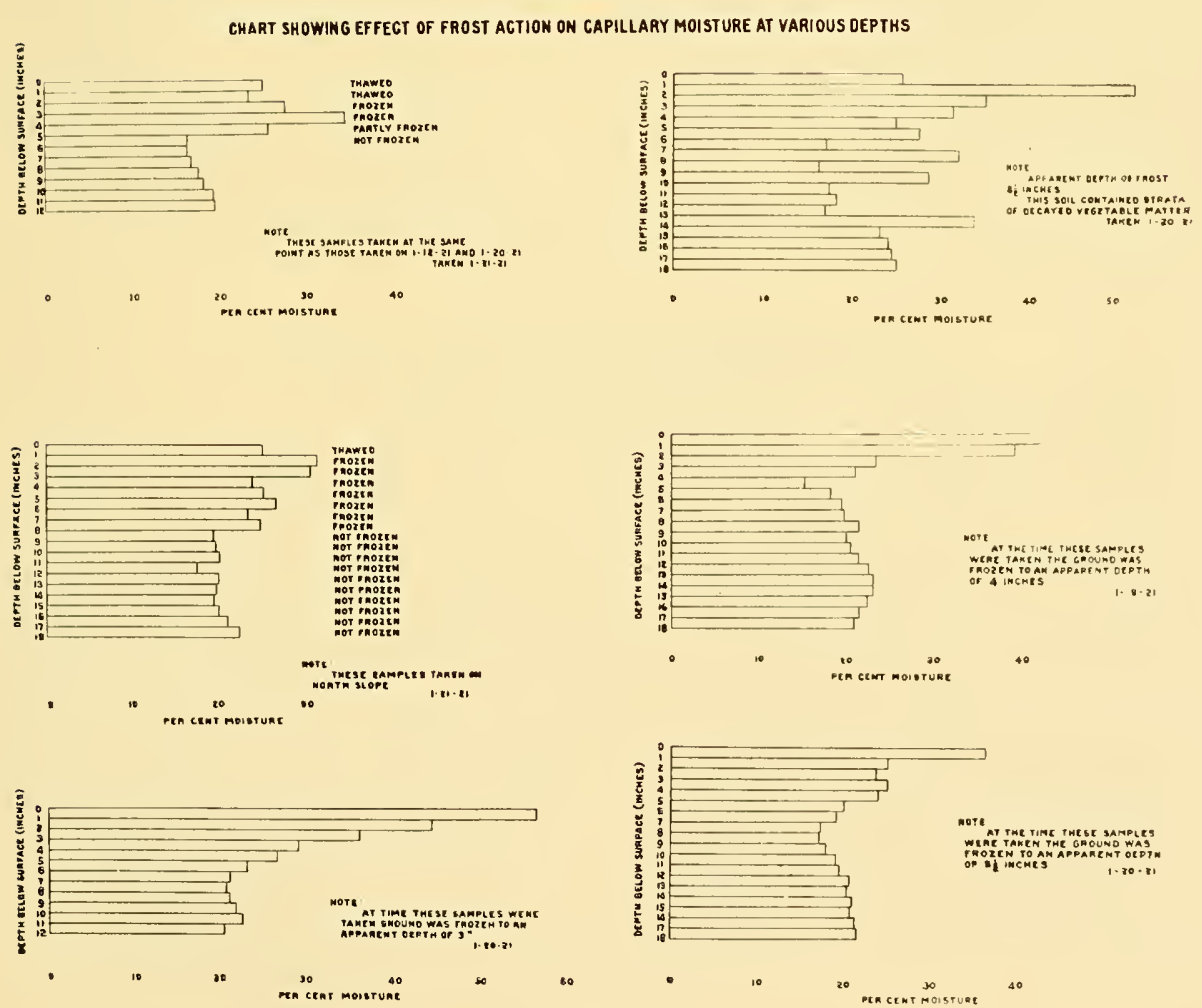
Figures 3, 4, 5, 6 and 7 . The highest moisture content here will be observed in sponge-like materials like cinders and granulated slag; the next highest will be seen in clays having admixtures of hygro-

Figure 2

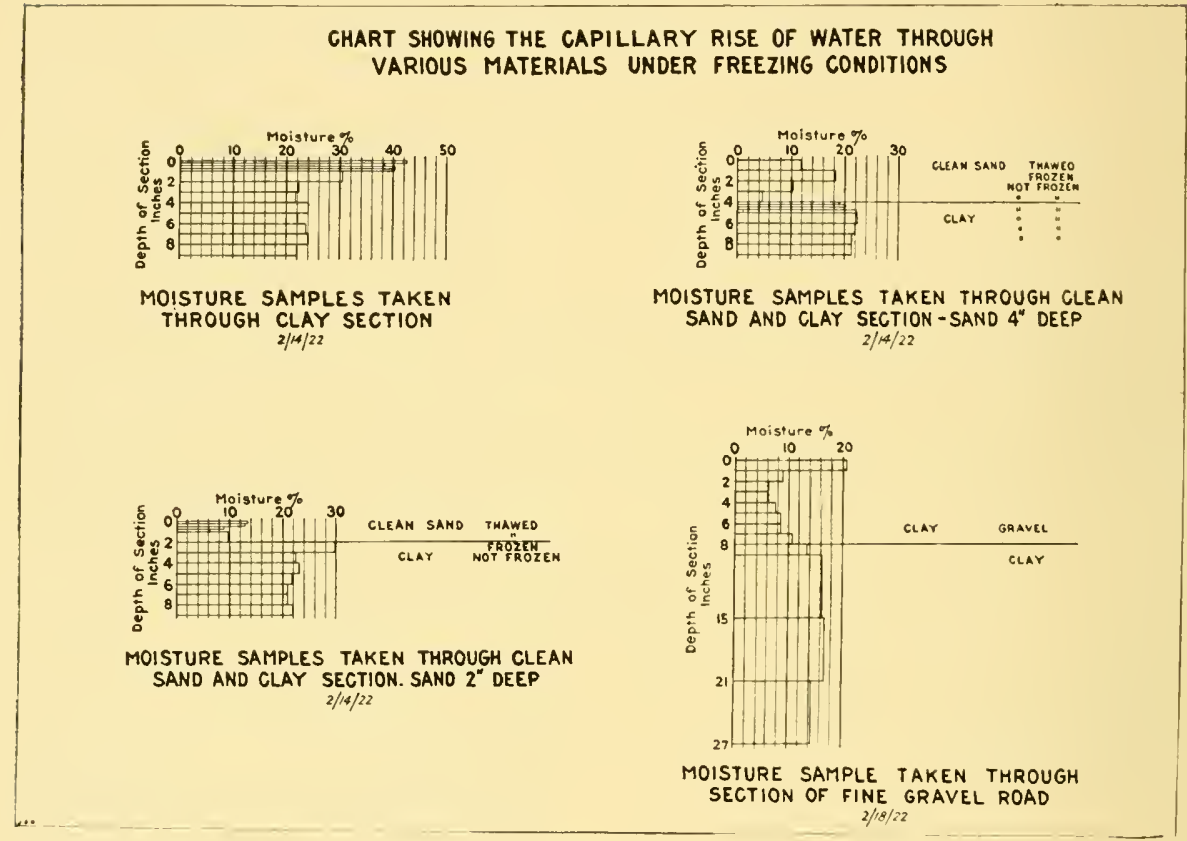

Figure 3

CHART SHOWING MOISTURE CONTENT OF SUBGRADES ON JAN. $18-19,1923$ AVERAGE TEMPERATURE OF AIR FOR LAST IO DAYS. $35^{\circ} \mathrm{F}$.

TOTAL PRECIPITATION FOR LAST IO DAYS.2.02 INCHES

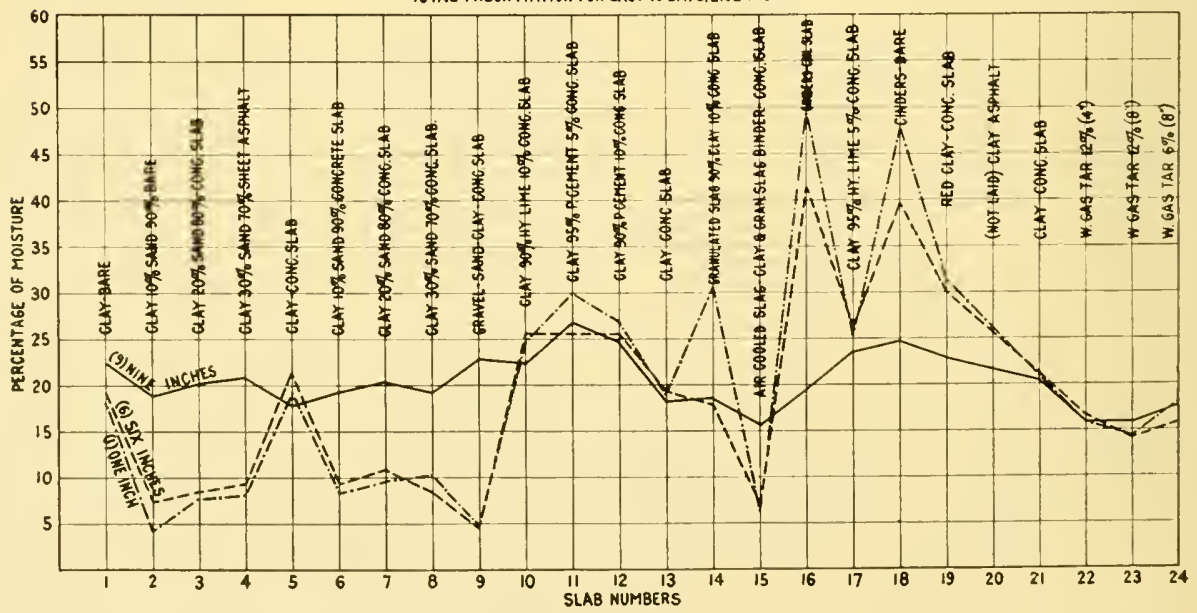


scopic materials like lime and Portland cement. Some materials, such as the many types of clays, take up considerable quantities of moisture when it is arailable and expand in volume, while other materials, like sand, gravel, crushed slag, etc.. take up only enough

Figure 4

2.

CHART SHOWING MOISTURE CONTENT OF SUBGRADES ON FEB. 12-13,1923

AVERAGE TEMPERATURE OF AIR FOR LAST 10 DAYS, $33^{\circ} \mathrm{F}$

TOTAL PRECIPITATION FOR LAST IO DAYS, 0.93 INCH

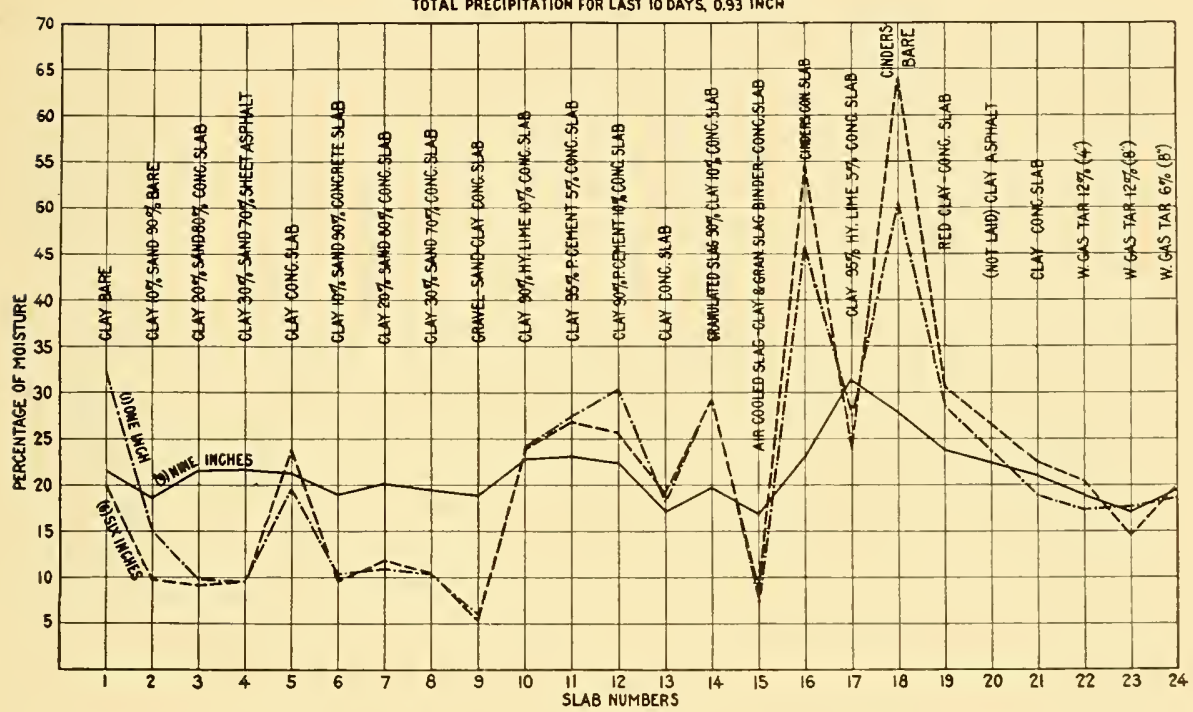

Figure う

CHART SHOWING MOISTURE CONTENT OF SUBGRADES ON MARCH 27.1923

AVERAGE TEMPERATURE OF AIR FOR LAST 10 OAYS $45^{\circ} \mathrm{F}$

TOTAL PRECIPITATION FOR LAST IO OAYS, L.44 INCHE'

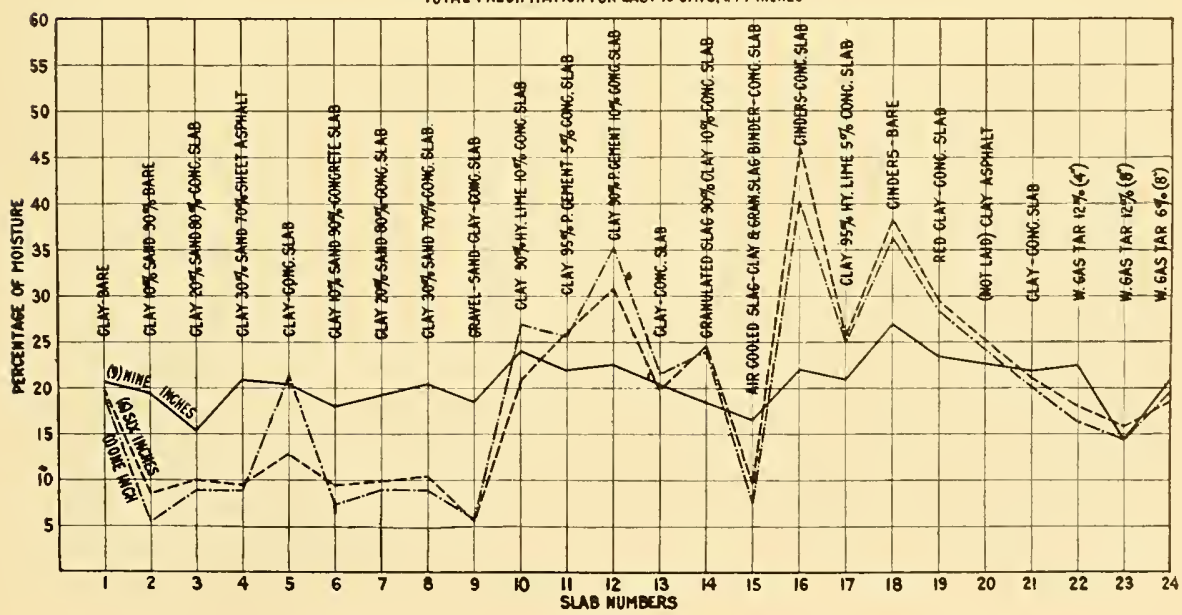




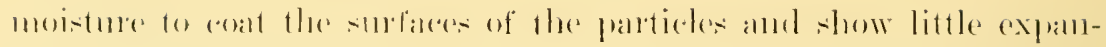

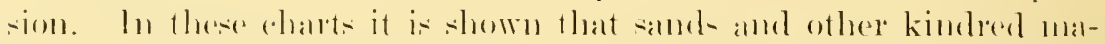

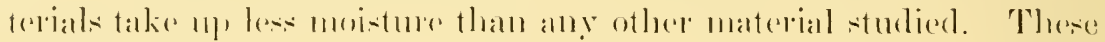

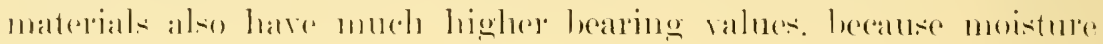

\section{Figulie 6}

CHART SHOWING MOISTURE CONTENT OF SUBGRADES ON JUNE I,1923 AVERAGE TEMPLRATURE OF AR FOR LAST 6 DAYS 75\%.

TOTAL PRECIPTATION FOR LAST 6 DAYS 1.75 INCHES

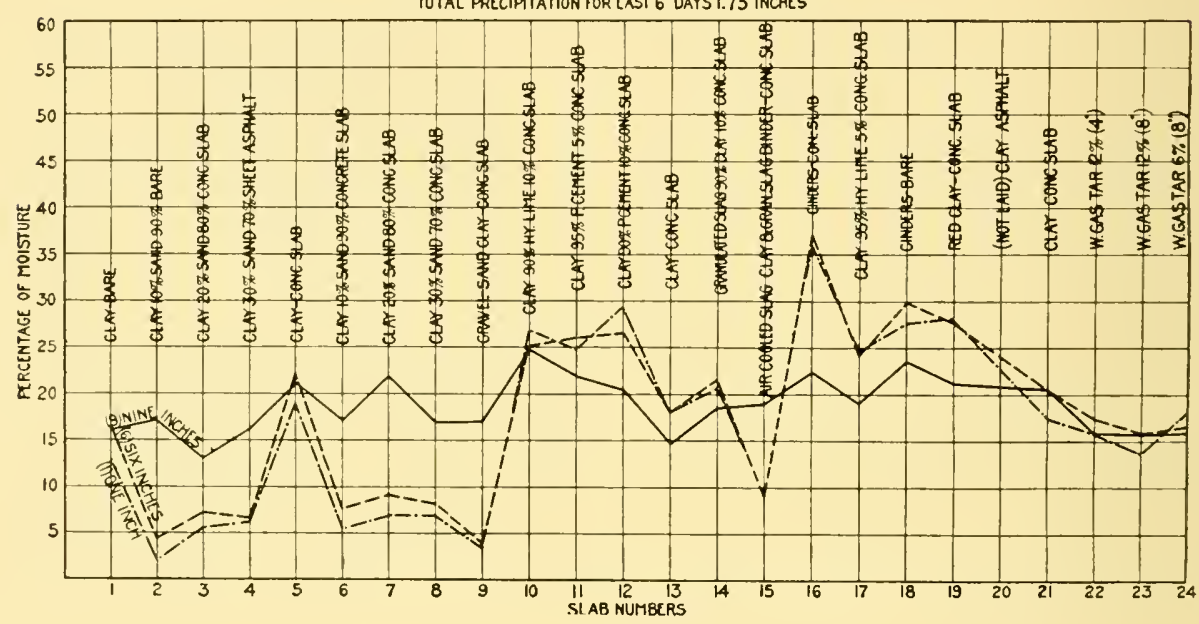

Figtre 7

CHART SHOWING MOISTURE CONTENT OF UPPER INCH OF SUBGRADE ON DATES INDICATEO

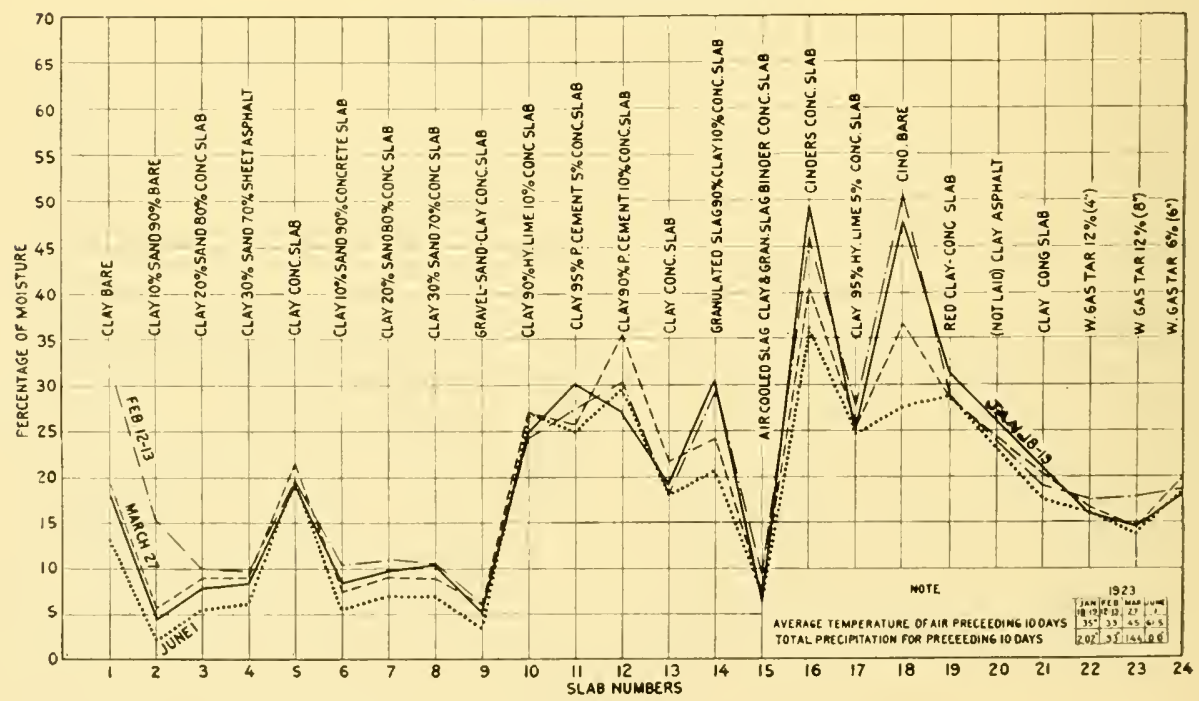


(eapillary moisture) does not decrease their bearing values to any marked extent.

It seems to be evident that the characteristics of any soil are dependent on the relative percentages of the particles of different characteristics present, and for this reason clay soils having high expansion, high moisture capacity and low bearing value when moist may be greatly improved by sand admixtures, resulting in a soil of lower moisture-holding capacity, lower volume change and higher bearing values. Such admixtures might be used to create an artificial subgrade over bad soils. The necessary depth of such artificial subgrades for various roar types has yet to be determined.

When macadam or broken stone bases are used over a heavy clay subgrade, it of ten happens that the clay is forced up through the voids in the stone and renders the broken stone layer much less resistant to loads and much more liable to damage through the expansion action of frost. Experiments, both of a laboratory nature ${ }^{1}$ and by actual use in roads ${ }^{2}$, show that a blanket of sand or similar material interposed between the subgrade and the broken stone is effective in preventing the clay from working up through the overlying stone layer. This statement is borne out by the experience of railroad engineers who have used cinders under broken stone ballast over bad subgrades.

Freezing of moisture in soils: The principal apparatus for freezing soils artificially is shown in Figure 8 . All other apparatus has been abandoned long since and no mention will be made of this equipment. In no case have we been able to check results with any apparatus for freezing except the one shown in Figure 8. With this apparatus we are able to check to within 0.2 per cent. This shows that the method is satisfactory for measuring the expansion of the frozen moisture in the soil being tested.

It is now definitely known that the soil itself does not expand on freezing, but the expansion oceurs in the moisture alone. This is proved in this way: We determined the expansion of distilled water by actual measurement and found that 1 cubic centimeter of distilled water expands 0.1 cubic centimeter. This is the same value as that obtained by Dr. George J. Bonyouens, of the Michigan Agricultural College Experiment Station. Bunsen's data show an expansion of 0.09073 cubic centimeter per gram of water frozen, while Foote and Saxton, of Yale University, obtained a value of 0.09325 . The factor of 0.1 is sufficiently accurate for our purposes. as the method for de-

\footnotetext{
${ }^{1}$ Bureau of Public Roads experiments.

${ }^{2}$ Rhode Island practice.
} 


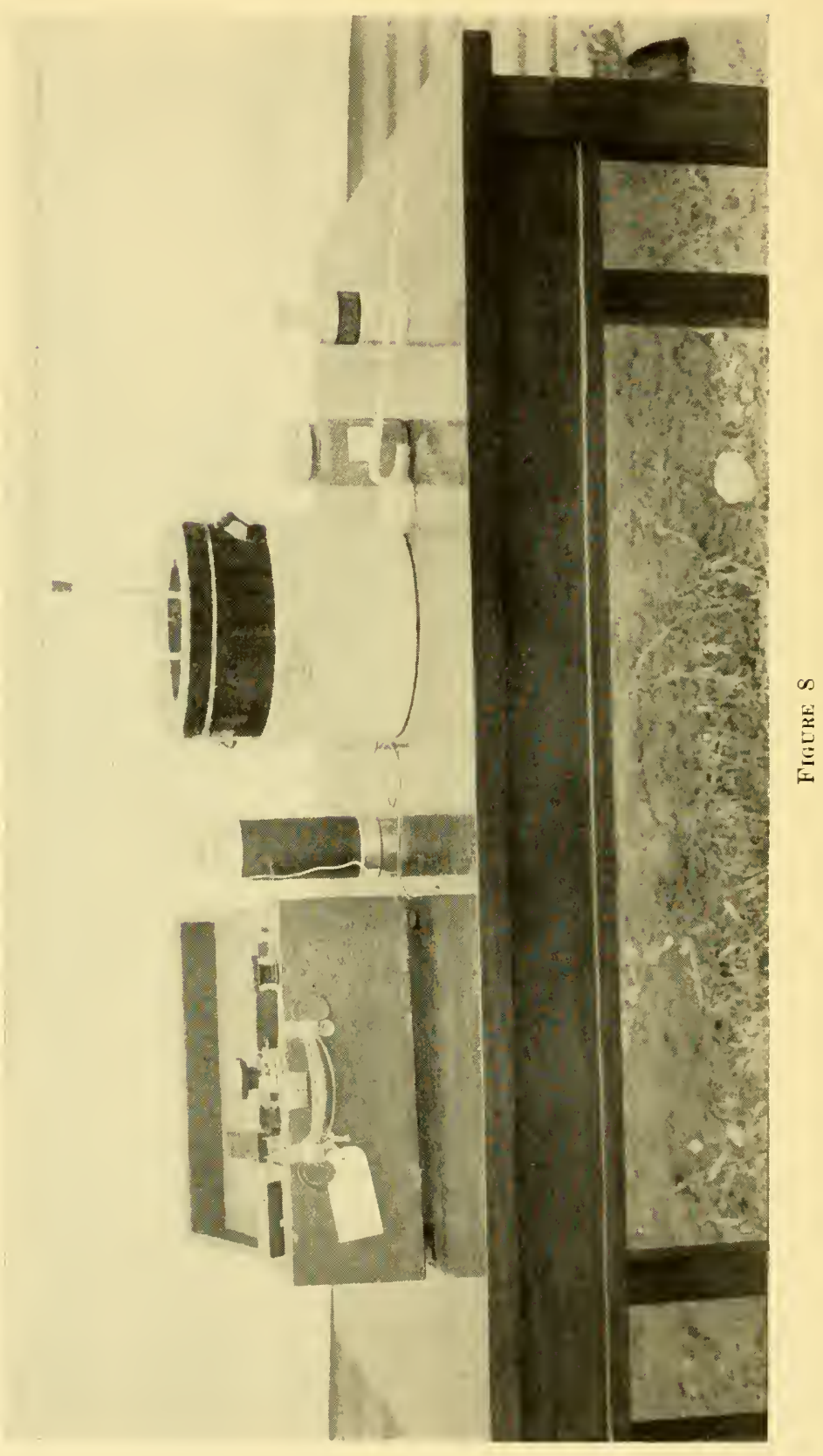


termining the frozen moisture in soil is vastly more precise than the uniformity of the soil. Checks are made only by the most accurate method of mixing and sampling.

We are able to freeze 100 per cent of the added moisture in Standard Ottawa sand, which is elean and free from dirt, but this same sand when reduced to silt which passes a 200-mesh sieve will permit of only 71.47 per cent being frozen. This phenomenon is mentioned to show what it means to have the water existing in a finer capillary state.

It was hoped that some relation might exist between the adsorption number and the percentage of moisture frozen, but it seems that this relation is rather remote. It is highly probable that a chemical analysis of the soil would indicate why there seems to be no such direct relation and would possibly funish "the missing link" in this work.

The table on page 82 gives typical comparisons between moisture frozen, adsorption and percentage of elay content for various soils.

It will be observed that in no case have we been able to freeze all the moisture in any soil, and by applying the factor of 0.1 it is possible to determine the volumetric expansion of the moisture frozen.

(b) I'RINCIPLLS AND METHODS FOR SANI-CLAY, TOP-SOIL AND SEMIGRAVEI, ROADS

The following methods and principles are subnitted hy Dr. Strahan, of Georgia, as the result of a number of year's investigation; with which, after discussion, the Committee on Struetural Design agrees.

1. These materials are to be classed as mixtures of loose aggregates wherein the larger sizes and particles (sand and gravel) have a stability due chiefly to mechanical interlocking or bond, and wherein the finer particles (silt and clay) increase the mechanical stability by filling voids and by greater or less adhesion, usually with the aid of moisture, to the larger particles.

2. The adhesion of the silt and clay to other aggregates and their own internal cohesion are due in part to the nature of the silt and clay, but are also largely influenced by the amonnt of moisture present and acting in a colloidal state on the fincly divided particles thereof.

3. The resultant strength under traffic of these materials is dependent upon mass action. The slabs must lave adequate thickness and monolithic consolidation. Packed in thin layers, weakness and early raveling may be expected. 
4. Mass action in such slabs takes advantage of -

a. Internal arching of the materials.

b. Resistance to direct compression,

$c$. Resistance to internal shears,

d. Resistance to diagonal tension when the silt and clay are adherive.

A Comparison between Moisture Frozen and Adsorption in Certain Soils

\begin{tabular}{|c|c|c|c|}
\hline $\begin{array}{l}\text { Soil } \\
\text { No. }\end{array}$ & $\begin{array}{l}\text { Moisture } \\
\text { frozen }\end{array}$ & $\begin{array}{l}\text { Adsorp- } \\
\text { tion }\end{array}$ & $\begin{array}{l}\text { Per cent } \\
\text { clay }\end{array}$ \\
\hline 290 & 84.0 & 6.3 & 16.0 \\
\hline 293 & 81.0 & 7.5 & 14.4 \\
\hline 158 & 75.6 & 2.5 & 5.2 \\
\hline 188 & 75.0 & 15.0 & 15.9 \\
\hline 29 & 74.5 & 25.0 & 29.3 \\
\hline 13 & 74.1 & 17.5 & 46.0 \\
\hline 5 & 70.0 & 7.5 & 11.6 \\
\hline 200 & 70.0 & 57.5 & 40.4 \\
\hline 201 & 70.0 & 15.0 & 20.4 \\
\hline 59 & 69.3 & 40.0 & 34.8 \\
\hline 56 & 69.4 & 18.8 & 28.0 \\
\hline 294 & 69.0 & 7.5 & 13.6 \\
\hline 202 & 67.2 & 25.0 & 18.0 \\
\hline 28 & 67.0 & 45.0 & 34.0 \\
\hline 119 & 66.3 & 20.0 & 45.6 \\
\hline 27 & 63.8 & 127.5 & 52.0 \\
\hline 60 & 63.5 & 87.5 & \\
\hline 80 & 62.3 & 22.5 & 41.8 \\
\hline 36 & 61.7 & 31.3 & 36.4 \\
\hline 14 & 61.4 & 55.0 & 48.8 \\
\hline 19 & 61.4 & 15.0 & 29.6 \\
\hline 25 & 60.8 & 150.0 & 45.7 \\
\hline 11 & 60.0 & 8.3 & 22.4 \\
\hline 6 & 60.0 & 22.5 & 32.0 \\
\hline 12 & 59.3 & 17.5 & 36.8 \\
\hline 291 & 59.1 & 7.5 & 19.2 \\
\hline 120 & 57.5 & 50.0 & 76.5 \\
\hline 55 & 57.2 & 55.0 & 36.0 \\
\hline 92 & 57.0 & 35.0 & 32.0 \\
\hline 161 & 56.7 & & \\
\hline 50 & 55.0 & 38.8 & 38.8 \\
\hline 54 & 55.0 & 52.5 & \\
\hline 24 & 54.3 & 90.0 & 52.8 \\
\hline 186 & 53.8 & 35.0 & 35.0 \\
\hline 15 & 53.8 & 22.5 & 41.6 \\
\hline 67 & 53.4 & 130.0 & \\
\hline 157 & 52.5 & 110.0 & 45.6 \\
\hline 23 & 50.7 & 57.5 & 40.8 \\
\hline 26 & 50.7 & 154.8 & 60.4 \\
\hline 22 & 47.7 & 90.0 & 56.8 \\
\hline 392 & 47.7 & 32.5 & \\
\hline 32 & 47.5 & 42.5 & 33.2 \\
\hline 42 & 43.0 & 120.0 & 82.0 \\
\hline 44 & 33.1 & 140.0 & 71.6 \\
\hline 161 & 22.9 & & \\
\hline
\end{tabular}

* Burned. 
5. Full bearing and impact resistances are not developed near the edges of the uncurbed slabs. Weakness may be expected for a distance about twice the thickness of the slab from the outside edges if unsupported. Usually these materials are deposited in trenches with supporting shoulders.

6. Such slabs show some degree of elastic reaction, but not according to quantitative laws. Laboratory specimens for transverse break yield by tension for spans longer than twice the rertical depth of the specimen. For shorter spans the yield is by diagonal tension from the load point downward toward the point of support.

7. Successful roads require-

a. Graded mixtures eapable of making a dense mass on consolidation. The best mixes run as low as 20 per cent porosity.

b. Uniform composition, secured by thorough mixing.

c. Heary compacting from the bottom upward. This is usually done by traffic. There is need for a type of multiple-rim roller to hasten and unify the degree of compactness imparted to these roads during construction.

d. Mixtures with a liberal amount of coarse material above No. 60 sieve.

8. The detailed classification, percentage limits, and methods of laboratory analysis and tests are to be found in U. S. Department of Agriculture Bulletin No. 555, issued by the Bureau of Public Roads; and in University of Georgia Bulletin Vol. XXII, No. 5a, June, 1922.

The procedure is to separate the original sample as follows:

(1) The well-pulverized sample is weighed and passed through a No. 10 standard sieve. The residue on the sieve is called "coarse material."

(2) The material passing through the sieve is regarded as a "soil mortar" and is analyzed as follows:

Fifty grams are thoroughly shaken and rubbed with about 250 millimeter's of water, adding 5 millimeters of a 4 per cent solution of ammonia; allowed to stand 8 minutes and siphoned to a depth of 8 centimeters from the surface. Operation repeated until a clear supernatant liquid is obtained.

The fine sediment thus removed is called "clay" or "total clay." The total clay can be further separated by centrifuge into "suspension clay" and coarse clay. The washed residue is dried on a water bath and separated through a nest of sieves-Nos. 20, 60 and 200. All residue above the No. 200 sieve is classed as "sand." The residue 
passing No. 200 and canght in the pan is called "silt." The sand coarser than No. b0 sieve is a nost important eriterion. Unless it reaches or exceech 30 per eent. it is hopeles to expect a satisfactory soil mortar.

Cidasification OF SOL MoRTARs

\begin{tabular}{|c|c|c|c|}
\hline & $\begin{array}{l}\text { Class } 1 \\
\text { letecut }\end{array}$ & $\begin{array}{l}\text { Class B } \\
\text { Pet cent }\end{array}$ & $\begin{array}{l}\text { Class C } \\
\text { Perecent }\end{array}$ \\
\hline$\ldots \ldots \ldots \ldots \ldots \ldots$ & 9 to 15 & 1i) to 25 & 10 to 25 \\
\hline 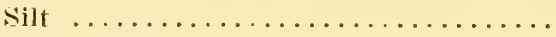 & 0 to $1 . \overline{1}$ & 10 to 20 & 10 to 20 \\
\hline 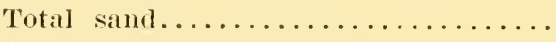 & 65 to so & (io to 70 & 55 to 80 \\
\hline Simd above No. 60 sieve........... & $\begin{array}{c}\text { tot to } 60 \\
\text { Hallel }\end{array}$ & $\begin{array}{l}30 \text { to } 45 \\
\text { Merdium }\end{array}$ & $\begin{array}{c}20 \text { to } 30 \\
\text { Soft }\end{array}$ \\
\hline
\end{tabular}

For further details see lubletins referred to alwove.

Coase material, abowe No. 10 sieve, has a decided influence on the durability, hardness and smoothness of the surface. Ten per cent of such hard. gravelly material, with a class li soil mortar, justifies reporting the whole as a Class $A$ matrial.

9. Extensive experience in the field and in the laloratory support the following comments:

(1) As to soils having no coarse material above No. 10 sieve:

a. Classes I and B, give respectively admirable and adequate traflic service for the expense involved. It is doubtful whether Class $C$ soil mortars should he used except on secondary roaks with very light traflic and when the material is close at hand.

b. The most important factor is the presence of roarse sand in liberal amount. Of course, clays aud silts differ markedly, but roads built of many different (days lave shown excellent durability. It will he noter that the total clay present in the best samples rarely exceeds 18 per cent. Efforts are, lowerer, being made to differentiate between clays by laboratory tests. and some tentative progress has been made.

r. It maty be accepited that the sand he?om No. lio sieve has little supporting value. It has some value in filling voids when coarser sand is present.

d. Highly organic silts luave binding value and strengthen the mixture, so long as the organic mattor persists, but such silts lose the organic matter quite dapielly by decay and dusting.

e. The more anhasive or highly aolloidal ("lays give effective bond with a little as ? per rent present. Less plastic clays 
are needed in larger amount up to a maximum of 25 per cent, but the mixtures with 20 to 2.5 per cent clay are apt to be slippery and cut into mind in long spells of wet weather.

$f$. Laboratory tests indicate that the adhesive values of clays are largely dependent upon the colloidal state of the material and the moisture present. Metal plates cemented together with thin films of clay show markedly greater adhesion when containing 5 to 10 per cent of water than when dried at $212^{\circ}$.

g. In general, it is believed that inorganie silts tend to diminish the strength of road soils, and noticcably so when present above 15 to $20 \mathrm{per}$ cent of the soil mortar.

(2) As to soils containing 10 per cent or more of hard coarse material above No. 10 sieve:

a. It is a matter of assured experience that such coarse material adds greatly to the durability of the mixtures. Such soils are found in many places and give rise to a series of semigravels reaching from 10 per cent up to the 50 or 60 per cent in a full gravel road.

b. $\Lambda$ good Class $A$ soil mortar with from 20 to 30 per cent coarse material gives a fine surface of marked durability. This is especially true of the iron-silica gravels in southwest Georgia, with from 25 to 40 per cent of a nodular ironimpregnated gravel, ranging from one inch downward. These nodules are not nearly so hard as true silica gravel, but are sufticiently strong to give most excellent service and very smooth travel.

The effect of wet weather

a. Moderate ground moisture increases the strength of all classes of these roads.

b. Long and heary rains influence them as follows:

Class C. Soften the surface so that wheel ruts two or more inches deep may appear under heavy vehicles, and when the sand is fine considerable material is washed down the steeper grades and into the side ditches. They do not show deep mud and are not slippery. Repairs are readily made with drags and road machines.

Class B. Soften only after very long and continued wet weather, wheel ruts rarely as deep as two inches, not much 
Washing into side ditches. Fasily repaired with road machines. Dry out promptly and are usually too hard for any but the heaviest metal drags and light road machines.

Class 1. Do not materially soften except where water stands for a long time in depressions. Wheel ruts rarely decper than one inch. The slab below this surface mud is generally hard and firm, and will require the heaviest road machines to reshape the surface. Dries off rapidly and soon becomes ton hard for the heavi. est road machines to cut.

c. Laboratory tests show that the road soils are of marked density, are not readily penetrated by rain on the surface, and when made into briquettes with varying amounts of water they retain the larger part of their tenacity until 15 to 25 per cent of water is added.

\section{Thicliness and crown}

The thickness used is designed to supply mass action and to provide ample shearing resistance against traflic pressures and impaets. The usual specification has been ten inches when packed in place. On weak subgrades, especially those subject to ground water saturation or eapillary lift from below, this should be increased to 12 or 14 inches. There seems little or no advantage in exceeding the above, for the following reasons:

1. Examination of the packed road slab shows that the hard pack rarely extends more than 6 inches deep. The material below this, while firm, is easily penetrated by a pick and comes up in small pieces rather than as a large clod.

2. The lower portion is thus functioning less actively in bearing resistance, but most probably it serves usefully as a drainage layer and also as a cut-ofl plane against capillary lift of water from the subgrade.

3. The surface wear of the better soils is not so rapid as to demand a large margin of extra thickness. The roughness which comes under wear after five to eight years will require scarifying and reshaping. The most expensive part of this process is pulverizing the clods, and the addition of new soil saves the necessity of much fine pulverization. It also restores the thickness of the original slab.

As to the proper crown, the earlier view adrocated a high crown, even as much as 1 inch per foot, but later experience has shown that one-fourth inch per foot is adequate and much more acceptable to the traffic. 


\section{Research investigations}

With the valued cooperation of the U. S. Bureau of Public Roads, there is in progress in Georgia, under its State Highway Department, an important and state-wide study of the effective life and economic results of 29 Federal Aid Projects built of these materials and under constant maintenance. The program embodies:

a. Samples taken at frequent intervals on each project at specified points and careful analysis of same. New samples are taken each year, and will continue to be taken until the surface must be reconstructed.

b. Traffic counts 8 days per month for one year, repeated in alternate years.

c. Careful field inspection (with photographs taken) made in summer and winter.

d. Taking of cost data on maintenance.

'Thus far, after 18 months, all but two of the projects show very satisfactory stability. These two were constructed of poor soils, not recommended by laboratory tests. Some of the projects have been under traffic for more than four years.

Incident to the above economic researcil, the laboratory is seeking to solve the very intricate problem of the specific interaction and influences of the gravel, sand, silt and clay in such mixtures. A great variety of tentative tests have been tried out. Attention is called to several of the more promising ones, as follows:

a. The Adsorption Test for Distinguishing Clays: This test was first devised and promulgated by the Bureau of Public Roads, using standard solutions of crystal violet filtered through and adsorbed by the material. Special filter tubes are used. (See Proc. A. S. T. M., 1922, Vol. 22, Part II, pp. 344-7.)

The possible ralue of this test as applied to original samples, to the separated ingredients, to the clay in particular, is easily seen. Further, the total clay itself can be further fractionally separated in a centrifuge and the adsorption of these fractions studied. This test has been followed on the soil samples from the 29 Federal Aid Projects with interest in this laboratory. It is noted that the soils and clays of this state show markedly lower adsorption ralues than the subgrade materials reported by the Bureau.

Change of the color medium to methylene blue has been tried out. In general, samples at this laboratory adsorb somewhat larger amounts of the latter than of erystal violet. Methylene blue also 
has certain adrantages of stability of color, and is not apparently influenced by acid or basic condition of the sample. Crystal violet is thus influenced in color. Further, the pure blue color is free from pronounced overtones. and a test by adding excess color, agitating vigorously or boiling can be applied and the excess determined in a colorimeter. Less time is required for this test than for the very slow filtration incident to the filter-tube method. This modification of the test is being fully tried out.

b. The Disk Shear Test: Results fairly consistent have been obtained by this test. conducted as follows:

Three disks, 2 inches in diameter and 1 inch high are prepared from each sample. The soil is moistened to stiff mud consistency and compressed under 3.000 pounds. I thin tin collar is used inside the mold, which aids the removal of the disk. The disks are dried in air or on the water bath. For test, the disk is inserted into the test cylinder and broken through in shear by the 1-inch steel plunger.

Conclusions by Committee.-1. Laboratory tests and procedure for determining physical properties of subgrade materials seem to be well developed.

2. Tile drainage and ditches remove only moisture in excess of capillary moisture in the soil.

3. Difference of temperature in soils tends to cause motion of moisture from the warmer to the colder layers.

4. Undesirable, plastic and finely divided soils are improved by admixtures of granular materials and small percentages of Portland cement and hydrated lime.

5. A blanket layer of granular material beneath the base course of macadam or gravel roads is effective in preventing settlement and penetration of the subgrade into the base course and tends in general to reduce heaving and displacement of subgrades.

(a) Folices ON PAVEMENTS RESTLTING FliOM TLAFHC

The following is reported by Mr. E. B. Smith as a result of the Bureau of Publie Roads" tests. They are to be reganded as preliminary results and are now being verified in a large series of tests in cooperation with the Rubber Association and the Society of Automotive lingineers.

Before strength designs may be definitely made, it is first necessary to determine the loads or forees which must he sustained. This applies no less to the design of a concrete road slah than to any other structure. The loads and forces to be sustained ly a road are thoso 
resulting from the action of traftic, and those most severe are mainly from heavy motor trucks.

A former series of tests were run abont two years ago to determine the value of impact of different trucks, and these investigations indicated quite a wide range of values. (See Mar. and Dec., 1921, "Public Roads.") The tests were rum orer a selected stretch of road on which were placed difterent types of obstructions. Under the condition of having an obstruction 1 inch high and with a $7 \frac{1}{2}$-ton truck fully loaded, running at 1.5 miles per hour. an impact value of 28,000 pounds was secured when using norn solid tires. Higher impacts were obtained when using higher obstruetions.

A later series of tests was run to determine the average impact that may be expected from different trucks traveling over a certain selected stretch of road. The trucks selected were a 2-ton Mack and a 5-ton Pierce-Arrow, both trucks being constructed with the usual rear-axle differential. In accolerometer of the new type was attached to the rear axle, which gave deceleration values of the unsprung weight, to which should be added the sprung weight on one wheel. The conditions of the tests and results are as follows:

1. 2-ton Mack Truck, No Cargo; Static Rear Wheel Load, 2,285

\section{Pounds}

a. Gravel road-bad ruts--high speed (15 to $18 \mathrm{~m}$. p. h.), 12,50018,500 pounds maximum impact force.

b. Gravel road-smooth-slow speed (. $\mathrm{m}$. p. h.), $7 / \mathrm{s}$-inch obstruction, 3,000 poumds maximum mupact force.

Gravel roarl-smooth-slow speed, -2-inch obstruction, 5,600 pounds maximum impact force.

Gracel road-smooth-moderate speed, Ts-inch obstruction, 3,300 pounds maximum impact force.

Gracel road-smooth-moderate speed, 2-inch obstruction, 8.000 pounds maximum impact force.

2. 2-ton Mack Truck, 3,000-pound Cargo; Static Rear Wheel Load, 3,735 Pounds

a. Concrete road (Columbia pike) running orer one experimental section at a time at about 8 miles per hour, the impact values varying from 6,600 pounds to $13,23.5$ pounds, most of the thirty-two sections giving impact values around 7,500 pounds.

b. Concrete roud-maximum impact value at maximum speed (about 15 m. p. h.), 20,100 pounds. 
3. 2-ton Mack Truck, 4,000-pound Cargo; Static Rear Wheel Load, 4,285 Pounds

The increase in cargo seemed to reduce the tendency of the rear end to jump, so that the accelerations oltained for this cargo load were consistently a little lower than for the smaller cargo loads and gave impact values which were slightly lower.

4. 5-ton Pierce-Arrow, 10,000-pound Cargo; Static Rear Wheel Load, 8,875 Pounds

a. Gravel road-smooth-7/8-inch obstruction.

8 miles per hour $-13,000$ pounds maximum impact force. 10

12 do. 15,000 do. do.

16,800 do.

Gravel road-smooth-2-inch obstruction.

8 miles per hour-22,500 pounds maximum impact force. 12 do. 28,700 do. 15 do. 33,700 do.

b. Concrete road- $7 / 8$-inch obstruction.

8 miles per hour-16,800 pounds maximum impact force. 10

12 do. 19,600 do. 15 do. 21,250 do. do.

27,800 do.

Concrete road-2-inch obstruction.

6 miles per hour-22,600 pounds maximum impaet force. 10 do. 34,000 do. 12 do. 36,800 do.

c. When running at full speed over 1/2-mile to 2 -mile stretches of typical concrete pavement at maximum speed (sometimes reaching 20 miles per hour on downgrades), impact values ranging from 28,300 pounds to 38,700 pounds were oltained.

These preliminary tests indicate that when driving over a typical concrete road at high speed with a fully loaded 2-ton truek, we may expect impact values of approximately 20.000 pounds. or over five times the static load on one rear whecl. With a fully loaded 5-ton truck at high speed, we may expect forces of 35,000 pounds to 40,000 pounds, or over four times the static load on one rear whecl.

The impacts as shown in the table represent the values usually ob- 
tained, but the maximum value of the force sustained by the road may at times be much greater, owing to the oscillating action of the truck body. If a downward movement of the loaded truck body occurs at the same instant as an impact, the two forces are, of course, additive, and the result may be possibly double the impact. Therefore, under certain bad surface conditions a total force of 40,000 to 60,000 pounds may be obtained at each rear truck wheel. The committee feels that the facts above stated were ascertained by careful test methods and concurs in the tentative conclusions.

(d) GENERAL CONCLUSIONS FRON FIRST SERIES OF TESTS ON PAVEMENT SLABS AT THE BUREAU OF PUBLIC ROADS

The following report is submitted by Mr. C. A. Hogentogler, of the Bureau of Public Roads:

These tests were conducted on slabs 7 feet square laid directly on the subgrade. They were subjected to impact of a specially constructed machine designed to simulate the blow struck by the rear wheel of a motor truck. Essentially, the machine consisted of an unsprung weight shod with a rubber tire and a sprung weight supported on the unsprung weight by means of a 5-ton truck spring. Repeated blows were struck in the center of the test specimens, increasing impacts being obtained by raising the height of fall.

First tests of impact on parements of the Bureau of Public Roads, carried on at the Arlington Experimental Station in 1920, a report of which was published in "Public Roads" for October and November, 1921, indicated that:

1. Resistance of $1: 1 \frac{1}{2}: 3$ concrete slabs 7 feet square to impact blows increased consistently with increase in thickness. Beginning with 4 -inch thickness, which resisted 14,000 pounds equivalent static load, the resistance of slabs increased 5,000 pounds with each inch of additional thickness. Specimens tested as beams, however, indicated that resistance to static loads varies as the squares of the depths.

2. The monolithic brick slabs (concrete base, $1 / 4$-inch sand cement cushion, cement-grout-filled brick tops) in most cases showed less resistance than $1: 11 / 2: 3$ concrete slabs of the same depth. The resistance of the eleven slabs on this particular subgrade was equivalent, on the average, to that of the concrete slabs having thicknesses of but 82 per cent of those of the monoliths.

3. Semi-monolithie slabs (concrete base, 1-inch sand cement cushion, cement-grout-filled tops) showed less resistance than the monoliths. The arerage of the resistances of four slabs was equivalent to that of concrete slabs having thicknesses of but 68 per cent of those of the semi-monoliths. 
I second large serios of impact tests is just being completed by the Bureau of Public lioals. but results are not available for the present report.

(e) RESLLTS ESTABLISIIED BY THE PITTSPUIR TEST ROAD IXVESTIGATION

The following eonclusions are stated by Mr. Lloyd Aldrich as a result of the sudies of the Pitsbure Test liond investigations:

Vote.--Reference should be marle to page numbers in "Report of Highway Research at Pittsburg, California, 1921-192.2."

1. The method of construeting the subgrade on adobe soil, as described, so reduced the objectionable features of this material that a reliable foundation for the parements resulted.

Reference (page 141; title, "Discussion"; subtitle, "Subgrarle").

2. This subgrade was not injured by the water which fillerl the side ditches for three months.

Roference (page 1+1; title, "I)iscuscion": subtitle. "subgrade").

$\therefore$. The unsurfaced concrete completely resisted all surface war due to solid rubber-tired traffic. The limited metal-tired travel indieated that it would cause, with sufficiently leavy loads, an early failure of surface.

Reference (page 141; title, "Discussion"; subtitle, "Surface Wear").

4. Early morning travel was more injurious to the parement than the day traffic.

Reference (page 14: : title. "Discussion": sultitle. "l)eflections: under traffic loads").

5. The observed deflections of the parements are very nearly directly proportional to the loads.

Reference (page 9.5; title. "Special 'T'unnel Studies": also, page 94. Plate 36).

6. Those sections that had steel placed in such positions as enabled it to resist the tension flexural stresses were more durable than those sections of the same dimensions that did not contain steel so placerl.

Reference (page 14.); title, "Disenssion": subtitle, "Deflections under traftic loats": also. Table 17 . page $14: 3$ : also, patae 140 . subtitle, "Effect of traffic on corners of plain and reinforeed concrete").

7. The rock ballast, as constructed under Section A, was less efficient than the earth subgrade.

Reference (page 14i); title, "Discussion"; subtille, "Deflections under traffic loads").

Note.-Further reforence in entire bonly of report. 
(f) GENEIRL CONCLUSIONS FROM TIE BATES ROAD TEST

Mr. Clifford Older has submitted the following conclusions as a result of the Bates Test at Bates, Illinois, conducter by the Illinois State Highway Department:

1. The endurance limit of conerete when subjected to repeated tensile stresses may safely be taken as not less than 50 per eent of the modulus of rupture of the material.

2. That the resistance to struetural failure of plain eonerete parement slabs of uniform thickness and laid on a uniform subgrade, when subjected to highway traffic loads, is in proportion to the square of the thickness of the slab.

3. That in plain concrete parement slabs overloaded by ordinary traffic, structural failure normally first appears at corner's formed by open eraeks or joints, which either intersect each other or the edge of the parement slab.

4. That corners formed by intersecting cracks or joints which are held in close eontact, either by compression set up by temperature expansion or artificial means, may be expected to resist struetural failure under loads much greater than those required to eause failure where the eracks or joints are open.

5. That in conerete parements having widths up to 18 feet, a center joint may be so designed and constructed as practically to eliminate the formation of longitudinal eracks and to insure a close contact along at least one edge of all interior corners.

6. That the contraction of concrete parement slabs concentrated at transverse joints or cracks, thus causing the formation of corners unsupported along either edge, makes necessary the strengthening of the edges of ordinary rural parements in order that such corners. as well as the edge of the parement, may aftord at least approximately the same resistance to struetural failure as the interior portion of the slab.

Another eonelusion reached was that soft tops, such as sheet asphalt, asphaltic concrete and bituminous-filled briek, may add slightly to the resistance of the rigid parements to structural failure when laid on good subgrades by minimizing the effect the daily warping of the slab has on subgrade support; but that this advantage orer uneovered eonerete parement slabs which are divided by eenter joints is so slight that it ean be practically neglected.

The eommittee has discussed with interest and submits the eonchusions suggested, respectively, by Mr. Aldrich on the Pittsburg road and Mr. Older on the Bates road. The eommittee will suggest under Part II further research endearors, which include some problems arising in connection with the above reports. 
(g) THEORETICAL ANALYSIS OF STRLSSES IN ROAD SLABS

A theoretical investigation of the mechanies of concrete slabs is now being undertaken by Dr. H. M. Westergaard for the Bureau of Public Roads. The following note is contributed by him:

"A contribution to the understanding of the mechanical behavior of eonerete roads should be obtained by applieation of the mathematical theory of elasticity. This theory has methods available for determining the distribution of stresses in an elastic slab resting on an elastic subgrade and earrying given loads. The resemblance of a structure of this kind to the road slab, with its subgrade, is sufficient to warrant the assumption that exact information concerning the perfectly elastic slab, when its dimensions and physical constants are chosen properly, may serve as approximate information eoncerning the road slab. Since it is possible by the theory of elasticity to investigate rather completely a wide range of eases, it appears to be a reasonable plan to obtain theoretical data for use as a basis for interpretation of experimental data and as a means for interpolating between the results of one test and another.

"A rather extensive literature deals with the theory of flexure of elastic slabs. Two papers deal with the subject of slabs on elastic support: one, by Hertz, was published in 1884; the other, by Happel, appeared in $1920 .^{1}$ Notable contributions to the general theory of elastic plates have been made during recent years, especially by Nádai, Mesnager, and Galerkin. ${ }^{2}$

"A theoretical investigation of the mechanics of stiff road slabs is in progress at present at the Bureau of Public Roads. So far, the assumption has been used that at each point the subgrade reaction is proportional to the deflection of the slab. Diagrams of deflections and bending moments have been obtained for various cases."

\footnotetext{
${ }^{1}$ H. Hertz: Über das Gleichgewicht schwimmender elastischer Platten, Wiedemann's Annalen del Physik und Chemic, Tol. 22, 1884, pl). 449-455, or in the Complete Works, Vol. 1, 1895, pp. 2SS-294. H. Happel: Úber das Gleichgewicht von elastischen Platten unter einer Einsellast, Mathematische Zeitschrift, Tol. 6, 1920, pp. 203-218.

${ }^{2}$ A. Nádai: Forschungsarbeiten auf dem Gehiete des Ingenienrwesens, 170. 171, 1915: Keitschrift des Vereines dentscher Ingenieme. 1914, p. 457; 1915, p. 169; 1922, p. 848; Schweizerische Bauzeitumg. Tol. 76, 1920, No. 23; Der Bauingenieur, 1921. p. 11. p. 299 ; Zeitschrift fïr angewandte Mathematik und Mechanik, 1922, p. 1. p. 381; Physikalische Keitschrift. 1922, p. 366. A. Mesnager: Ammales des l'onts et Clianssées, Mémoires, 1916. III, p. 313, and a series of short paper's in Comptes Rerulus, 1916-1919, Vols. 162-165, 168, and 169. B. G. Galerkin: a series of comprehensive papers in Russian, Annals of the Polytechnic Institute of Petrograd, 1915-1919, Vestnik Engeneroff, 1915 and 1917, and Bulletin of the Russian Academy of Science, 1919.
} 
P.ART II

\section{I'RUILEAS FOR FURTHER RESEARCH}

It is suggested by your committee that research should be conducted on the following problems in order to obtain further information leading to the establishment of principles of design:

1. Study of elastic properties of subgrade soils. Investigations should include observations on the flow of soils if they are only partly elastic. Research should also take into account that highway loads are moving loads of short duration many times repeated.

2. The transmision of preserte by various thickneses of micadann and grarel to subgrade soils. Such an investigation woutd cail for an observation of pressures for a period of several years following the original construction of the surface. Such an investigation should cover a wide variety of methods of construction and materials on different types of subgrade.

3. The mathematical analysis of stresses in rigid slabs (now under way).

4. Exhaustive measurement of streses in rigid slabs to confirm the mathematical analyses (now under way).

5 . Ascertain if the same or similar treatment of other heavy soils will make them impervious and good subgrade material as it did the heary black adobe at the Pittsburg tests; also, determine if such treatment will retard or eliminate frost action.

6. Determine the comparison or relationship, in a parement slab, of deflections and stresses under different loading conditions, with observations taken longitudinally versus transversely.

7 . Comparison of vertical and horizontal movements of a concrete parement due to moisture versus temperature.

8. Establishment of a basis of comparison of rarious asphaltic parements versus Portland cement concrete. Conditions: (a) Subgrade as nearly uniform in every respect as is possible to attain; $(b)$ Parement slabs of equal dimensions; (c) Identical atmospheric temperature and moisture conditions; $(d)$ Identical loading and traffic, and (e) The same installation of recording apparatus to measure the direct comparison.

9. The effect of longitudinal reinforcing on transverse temperature cracks in a Portland cement concrete slab.

10. The effect of an asphaltic top course on a Portland cement concrete base in changing the magnitude or rate of vertical motion due to temperature changes.

11. To determine the proper ratio of transverse steel to longitudinal steel and the maximum amount of each necessary in a reinforced concrete parement slab to safely withstand unlimited repeated 
applications of, say, single axle loads of ten tons, without impact (this in conjunction, of course. with fair arerage subgrades).

12. To conduct further practical studies of the effects on parements of various types of motor vehicles, including tires, springs and various accessories now on the market.

13. To evolve some simple means of predetermining the usefulness of a finished subgrade made of the rarious soils, if it be properly prepared to get the best known results. (This is quite aside from the present method of determining bearing power.)

14. To confine our highway research, for the present at least, to pavement slabs between the limits of five and seven inches in thickness. The balance of the study can well be spent on the preparation of soils in seeuring proper subgrades for such parements which would then safely carry any present-day traffic.

15. Need of dowels in two-section pavement.

16. The increment of strength added to parements by thickened edges.

16a. Are thiekened edges along center joints necessary?

17. The effect of crown subgrade on drainage.

18. To devise a method of surfacing sand-clay, top-soil and gravel roads similar to veneer surface as being carried on by North Carolina.

19. More definite information as to the arerage and maximum value of the load and impact force that have to be considered for each type of road.

20. The relative destructive effect of different types of rehieles (this with reference to types and weights of axles, chassis, and load distribution).

21. Importanee of proper tire equipment.

22. A simple and definite method of testing tires to determine relative cushioning quality.

23. Relative stress effect of statie and impact forces on materials.

24. Deformation and modulus of elasticity of materials under impact.

25. Investigation of merits of reinforcement and special joints in carrying loads across adjacent slab.

26. Study of methods of compaction of fills of various kinds of materials.

27. Distribution of pressure intensities under road slabs.

25. Further sturlies on effect of climate and suow on moisture in the subgrade.

29. Further study of beneficial effect of admixtures on plastic subgrade and the depth required.

Note.-Subgrade tratment, 8 inches thick. 
Dr. H. M. Westergaard, University of Illinois, gave an illustrated progress report of investigations on the "Mechanics of Stiff Road Slabs." This report is not yet available for publication. A brief summary by Dr. Westergaard is given:

This work was carried on during the summer of 1923 by the Bureau of Public Roads and is being continued at present at the University of Illinois for the Bureau of Public Roads. The method of the investigation is that of the mathematical theory of elasticity. The nature of the problem is as stated in the note on theoretical analysis, embodied in the report of the Committee on Structural Design. The problems yet to be solved are the problem of local stresses in the immediate neighborhood of a wheel load, and the problem of the effect of a non-uniform subgrade. When the results of the investigations are plotted in the manner of test data, they should furnish a means for interpreting the results of tests.

\section{REPORT OF COMMITTEE NUMBER 3, ON CILARACTER AND USE OF ROAD MATERIALS}

In the absence of the chairman, Dr. Hatt gave an outline of Mr. Mattimore's report. The report follows:

A meeting of this committee was held at Harrisburg on October 4 for the purpose of receiving and acting on reports pertaining to problems which had been assigned to individual members of the committee. Those present were B. A. Anderton, R. W. Crum, F. C. Lang, C. S. Reeve and H. S. Mattimore; or an attendance of five out of a total membership of seren.

The twelve problems assigned to individual member's of the committee for investigation were considered to be subjects upon which no definite conclusions have been drawn by research workers in the highway field. Their importance is recognized by highway research workers and it is considered that a solution of many of them would be a step forward in quality control of both concrete and bituminous surfacing, and may result in correcting many defects in both types of highway surfacing. These research problems are as follows:

Problem

1. Soundness Test for Iggregates in Concrete.

2. Soundness Test for Concrete.

3. Effect of Grading of Fine and Coarse Aggregate in Concrete.

4. Determination of the Amount of Cement in Hardened Conerete.
Assigned to

II. O. Withey.

R. W. Crum. 
5. Significance of Modulus of Rupture Tests for H. H. Scofield. Concrete in Road Slabs.

6. Signifieance of the Jones Talbott Rattler as Tests for Concrete in Roar slabs.

7. Alsorption of Concrete as Effected by Agregate, the Ultimate Effect of this in Expansion of Roarl Slabs.

S. Signifieance of Ball 'Test (Penetration of $1 \frac{2}{2}$ inch Steel Ball under Pressure in Conerete and Mortar).

9. Strength of Cast Concrete versus Drilled H.S. Mattimore. Specimens.

10. Strength of Hardened Concrete in Wet and Dry Condition.

11. Effect of Grading of Mineral Aggregates on Sheet Asphalt and Bituminous Concrete Construction Relative to Deformation of Surface under. 'Traffic.

12. Recovery of Bituminous Materials from F. C. lang.

B. A. Anderton. Roar Surface Mixtures in Original Condition.

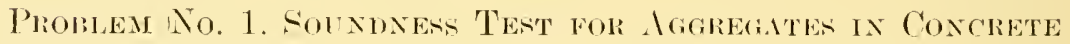
Problem No. 2, Soundess Test for Concrete

So far as the committec can ascertain, very little research work has been done on these problems. The eommittee is of the opinion that aceelerated tests, both on aggregates and concrete, endeavoring to duplicate atmospheric action, are one of the vital needs in this field. The Sodium Sulphate Test ${ }^{2}$ might prove to be valuable for this purpose, and it is recommonded that rescarch workers give consideration to it.

\section{Probley No. 3, Effect of Grading of Fine and Coarse drgiegate ia Concrete}

The report submitted gives the present status of research on this subject. Sereral theories for proportioning concrete, devised by research workers, have been compared, and the following are some of the conclusions taken from the full report:

Established facts and principles._ "As a result of the work of the varions authorities, the following fundanontal fact has been practi-

\footnotetext{
"Proposel soundness Test for Concrete Igerenate," Uniterl states lepartment of Agriculture, Fiulletin No. !) 4!. lilige (i2.
} 
cally established. The strength of Portland cement concrete varies with the amount of actual solid material present in a given volume and with the relative parts of this volume that are cement and aggregate. Different experimenters have expressed this relation in different ways, but appear to be in substantial agreement as to the underlying principle."

"The fact having been established, that for the same amounts of cement and aggregate, other conditions remaining the same, the strength of concrete varies with the amount of mixing water, it readily follows that concrete shonld be mixer with as little water as will yield a workable mixture for the nse at hand. It has also been reasonably well established, other conditions being the same. that the grading of the aggregate has a deciled effect upon the amount of water that may be used to yicld a workalble mixture. We have here, therefore, an explanation of the benefit of using well-graded aggregates."

Controversial fuctors.- "The varions suggested nethods of evaluating the sieve analyses of aggregates have not ret heen reconciled or the fundamental laws fully established. Conerete has been designed and made both experimentally and in actual construction, with sucress, by earth of the varions methors. The 'Fineness Mordulus, " and the "Surface area" methods depend upon a complete sieve analysis. Prof. Talbot's mortar void method ${ }^{3}$ depends upon the characteristics of the mortar portion of the conerete. The Iowa IIighway Commission ${ }^{+}$has used mixtures bawed upon the ratio of fine to coarse aggregate.

"It can be shown that with materials from a given source these rarious functions have definite relations with each other, but that witlı randon materials from different sources no such definite relation obtains. It is probalble that equivalent concrete mixtures can be designed by each methor for aggregates generally similar, but varying in grading."

Recommendations. - "The committee recommends that research tending to coordinate the data now available be encouraged, and that research to develop methods of making nore uniform concrete upon a large seale be strongly urged upon all interested ageneies as prerequisite to making effective use of the information already available on the design of concrete mixtures."

\footnotetext{
${ }^{1}$ Bulletin No. 1, Structural Materials Research Laboratory, Lewis Institute.

"I'roceedings A. S. T. M., Vol. 1s, 191s, page 2:36.

${ }^{3}$ I'roceedings A. S. T. M., Tol. 21, 1921, biae 940.

t Fulletin No. 60). Eng. Fxp. Station, lowa state College.
} 
Promlem No. 4, Detemination of the Myount of Ceinext in Hirdened Concrete

This report should be a valuable guide to research workers in this field, as it takes up the present status of the problem, with tabulation of the past work and the work at present under way.

No report has been submitted on Problems Nos. 5 and 6 , but a subcommittee is engaged in this work and expects to submit some data. at the next meeting.

Problem No. 5, Significance of Modulus of Rupture Test for Concrete in Road Slabs

The committee considers Problem 5 a very important subject. There are considerable data at the present time on this subject, the importance of which for the testing of concrete road slabs is recognized.

Problem No. 6, Significance of tile Jones-'Talbott Rattler as 'Tests for Concrete in RoAd Stabs

The committee does not consider that data obtained at the present time indicate that this is a reliable test, and they question that it should be placed in the status of an inportant or essential test for concrete when used in road slabs.

Probley No. 7, Absorption of Concrete as Affected by AggreGate: the Ultinate Effect of this in Expansion OF ROAD SLATS

The full report on this subject gives the status of the research to date. The committee consider's that this is a very important problem and that research along this line should be encouraged. An investigation of the absorption of concrete. combined with temperature changes to which it is exposed, may result in some solution of the cracking and rupturing of concrete bases and road surfaces.

Probieli No. S, Significance of Bill 'Tlest (Penetration of 1/2incil Steel Ball Under Presstie ix Concrete axd Mortar)

The research on this problem, so far as the committee is informed, has been limited-in fact, confined to one agency ; but it is the opinion of the committee that if the test proves to be a reliable indication of the compressive strength and effect of fatigue on concrete slabs, further development should be encourager. The weak feature

1"Ball Test Applied to Cement Mortar and Concrete." Rulletin No. 12, Engineering Experiment Station, Purdue Vuiversity, Lafayette, Indiana. 
of this test in its present state seems to be that the penetration of the ball in a concrete mix is affected when coarse aggregate is encountered.

\section{Problem No. 9, Strexgth of Cast Concrete versus Drtlued Specimens}

Considerable data on this subject have been secured and compiled. The data to date have not shown any direct relation between cast and drilled specimens, but it is the opinion of the committee that, while some such relation should exist, lack of control and absence of detailed data on the field concrete make it difficult to trace the relation. For guidance of research workers on this problem, a research outline is given ("Strength of Concrete as Determined from Moulded and Drilled Specimens").

Problem No. 10, Strexgtil of Hardened Concrete in Wet AND DRY CONDITION

The general conclusion that could be drawn from this report is that concrete when tested in a wet condition shows a decrease in strength over that which is tested dry.

The moisture content of concrete spccimens when tested may be a large factor in the variables present in concrete testing; therefore, it is considered that this is a factor that should be taken into account by research workers in the concrete field.

Problem No. 11, Effect of Grading of Mineral Aggregates on Sheet Aspilalt axp Bituminous Concrete Construction,

Relative to Deformation of Surface under Traffic

The report gives the present status of this problem. It is surprising that so little conchusive researeh has been carried on in this field. All investigators emphasize the need of more information. 'The committee considers this a very important field for research.

\section{Problem No. 12, Recovery of Brtuminous Materials from Road Surface Mixtures in Original Condition}

The full report on this problem diseusses several methods now in use for the recovery of bituminous materials from mixes. Conclusions are also drawn regarding the efficiency of the various methods, and a suggested line for further research is presented. The committee considers this an extremely important subject, in that if we had an exact method for recovering bituminous materials in their original condition we might be in a position to determine some of the factors which cause the pushing and cracking of bituminous road surfaces. 
In endeavoring to compile research data mon bitmminoms mixes. the committce foumd that rery little work of a broad researeh nature had been earried on. This field should be a fruitful one for highway researeh workers. The following ooncise statenent is given in an endeavor to impleses upon highway reseateh workers just how innportant this field is:

"Research upon bituminous materials, particularly as used in paring mixtures, inchules a number of problems upon which it would be desirable to have much more comprehensive information than is available at present. Discussions in recent years as to the causes of

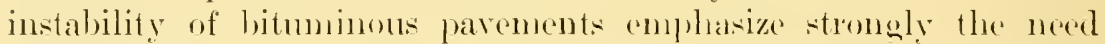
for investigating the properties of mixtures of this mature. The problem is difficult of attack on account of the great variety of matrials. proportions, methods of preparation and construction. and becaltse of the interdependence of many factors to be controlled and measured simultaneously. Such resarch requires special equipment, derelopmont of testing apparatus and methods, thorough investigation in a hoad field of possible combinations of matrials. and will probalily necessitate considerablo time and expenditure for the obtaining of emmorehensive data. It is worthy of the most extensive amd hest thought which may he brought to bear on inrestigation of road materials."

Rescarch outlines, entitled "Outline Investigation of stability of Bituminous Surface Mixes" and "Strength of conerete Ictermined from Moulded and Drilled specimens," are attached for the guidance of the workers in this field.

Chairman Johnson gave the meeting over to a gencral discussion of the various reports and papers.

Mr. Older: Results oltatined hy repeated soil-bearing tests an the

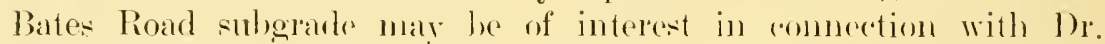
Westergaard's report. Loarls of varying anomnts wore atpplied to concrete slabs, east in place on the subgrale, fon to fifteen times at short intervals, followed by rest periods. The first loal alplied alter a rest period invarialuly resulted in a marked permanent depression of the subgrarle soil. This permanent depression alwass seemed to appear, even although the rest period amounted to only a few minutes. Furtler, the repeating of a number of loads at frequent intervals seened to result in eontinued permanent depresions. although apparently on a recreasing sale as the number of repotitions of load increased. As might be expected, there is somr indiuation that as the moisture content of the soil incorases alphoximately to the point of saturation, the permanent deprescion callsert by wate alpplication of loat increstes quite rapidly. 


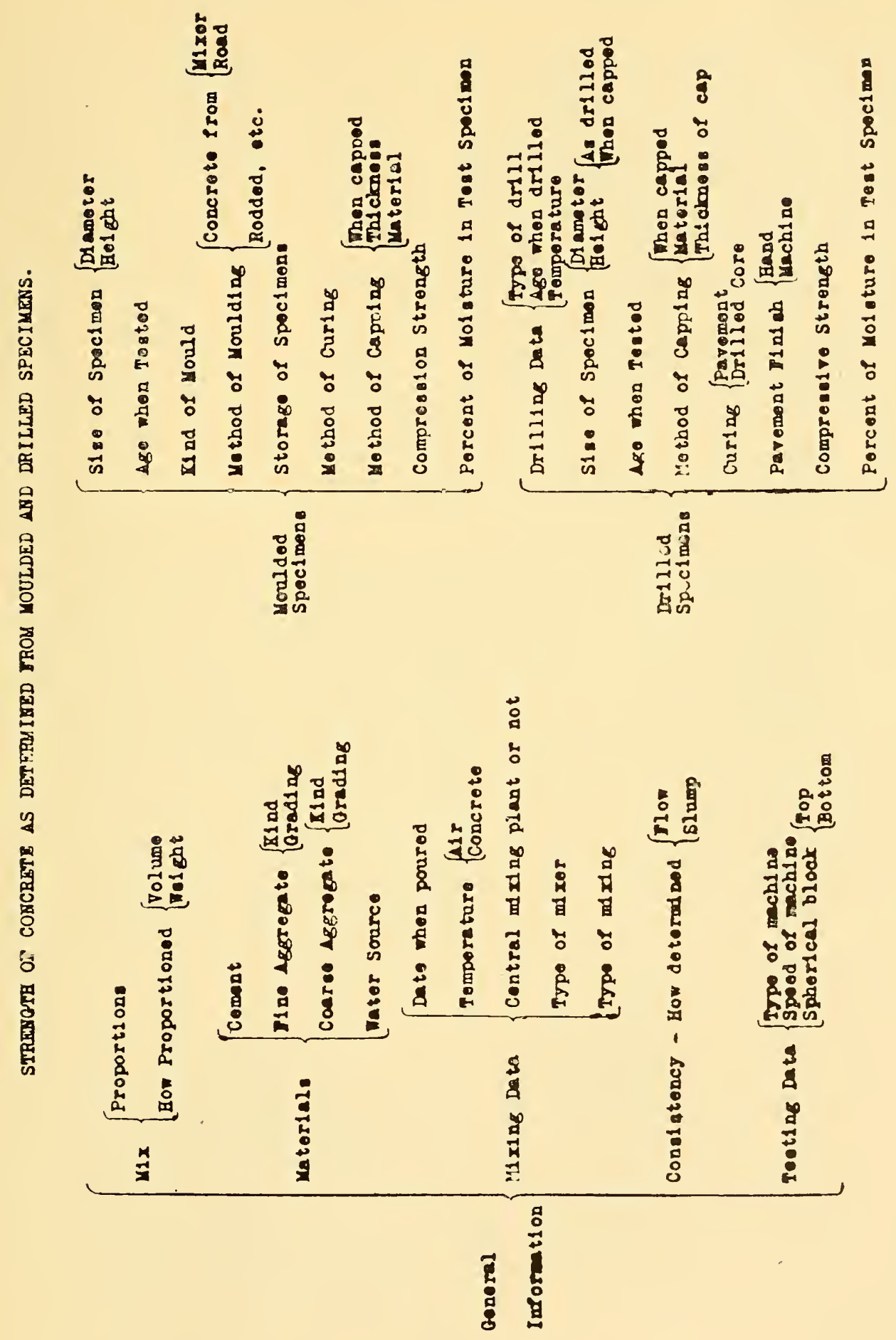


볼

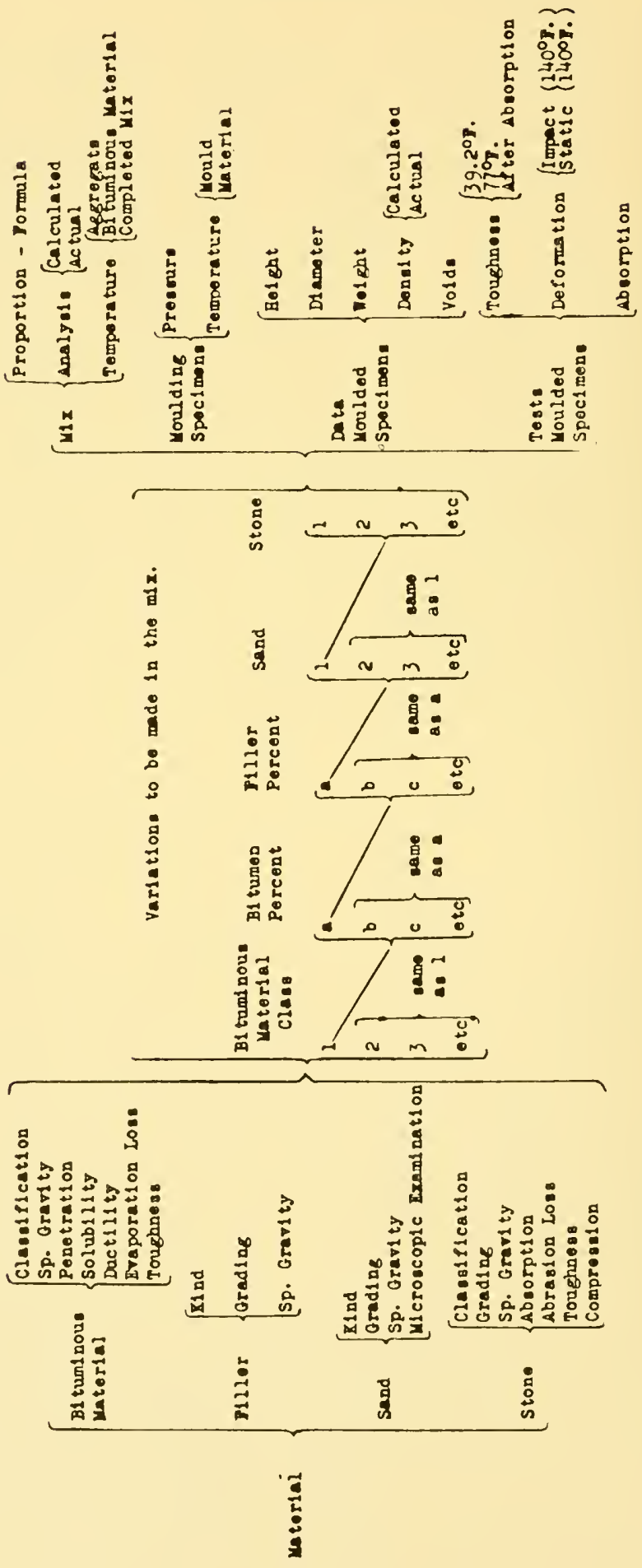


The observations so far made indicate that at least one other item may have an extremely important bearing upon the behavior of a clay sulgrade soil when subjected to repeated loads. This relates to the effect produced by freezing and thawing of the soil. During the summer and fall months, when the moisture content was about $2 \mathrm{~S}$ per cent, ten repetitions of a load amounting to 6 pounds per square inch might result in a total permanent depression of perhaps not more than 1-100 inch. Later, when the moisture content had increased under the same slab to about 33 per cent, in the meantime the ground having frozen and thawed a few times, ten applications of a load of the same magnitude produced a permanent depression of 16-100 inch. Still later, after another period of freezing and thawing, during which the moisture content had again decreased to about $2 S$ per cent, ten applications of the same load produced a permanent depression of about 6-1000 inch. It would seem that north of the latitude where freezing and thawing of the subgrade may be expected this phenomenon would have an important bearing upon the subgrade problem.

Dr. Westergaard: It is possible that ruts can form under the pavement, provided the traffic follows definite tracks. I believe, then, that one of the particular problems that should be dealt with theoretically is the matter of the flexure of the slab having less support along two different lines. I believe that problem can be handled. Now, as to the matter of permanent sets in general, a committee on stresses in railroad tracks has been confronted with that same thing.

\section{Second Session}

The meeting was called to order at $7: 30 \mathrm{P}$. MI. The Chairman introduced Thomas H. MacDonald, ehief of the U. S. Bureau of Publie Roads, who made an address on

\section{TIIE OBJECTIVES IN HIGHWAY RESEARCH}

The United States is now carrying on a highway improvement program which, measured in terms of expenditures, approximates a billion dollars annually. As in nearly everything else of concern to the general public, we have gone in for quantity production. A large yearly mileage of new roadways has been demanded, that a place might be found upon which to operate the quantity production of the motor vehicle. So large are the annual programs of new construction in many states that even minor modifications in specifications or designs have a very large financial aspect.

In the face of large annual increases in the mileage of improved 
roads, handicaps exist and have existed continually to the satisfactory and economical use of the notor vehicle hecause of insutlicient mileage of highways improved to even reasonably acceptable standards. Very recently a well-known manufacturer stated that four million new vehicles would be placed on the highways in 1!).2t. Eron allowing for the retirement of a large number of those now in service, the net accrement is such there is the certainty that much greater service will be required from highways already seriously orerloatled structurally and congested to the point of disconlaging the reasonable and desired use of the motor vehicle.

All this has oceurred without waming and without precedent. The whole development of highway transport is in the making. hringing with it hundreds of problens-social, economic and enginecring. This condition must be recognized, acecpted with just weight, and solved. Much greater reason exists for doulting whether the condition now existing will be eorrectly meatured than for doulting the ability to apply proper remedies, once the individual problems are correctly amalyzed. In no other development. andeient of modern, aflecting in so major a degree the whole structure of our social and economic life has the engineer been givon so commanming an opportunity for leadership and for carryog into effect policius formmlated by his profesion.

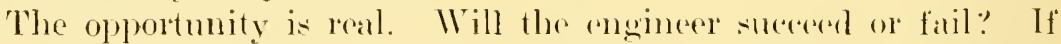
he is making progress, if he is sueceeding, if he finally proves leeyoud all doubt the ability of the engineer to master. and thes to lead in a new and major translation in om national life, it will be thromeh research-research that is as lige and hoarl, as sympathotic and intelligent, as the present existing conditions and oplontunitie: for: ardvancement and progress justify.

I satisfied confidence in present practices and a lack of interest in engaging in and supporting broad highway research is not only a failure of a public duty, but it is the worst possible betrayal of the engineering profession itself. But past history is not entirely lexassuring. One question for years has been to me a nost perplexing one, and I may add it has not been an entirely lappy one. This sane que-tion has been active in the minds of a great many, if not most, of the enginering profession, and eommon reference is marle to it in engineering literature.

It is this: Considering the study, prepartition and experience mquired to fit one arlequately to practice the profession of engineseing, the hard work, both mental and physical, wsually involved in the pratice of the sereral hranches of engineering. the sincerity and persistency of purpose required for any sucessful aceomplishment, 
and the responsibilities of all kinds inposed, why has not the engineer been accorded more readily and more consistently leadership and the rewards of leadership, not necesarily material, which generally acerue to recognized authority?

And the answer. which is reasonably sufticient to me, but which I do not insist that any one else shatl accept, is this: the lack of engineering research. As we review engineering history, this lack and often entire absence of anything approaching adequate research has been until very recent years characteristic of both individuals and institutions.

For example, agricultural experiment stations have been establisher through federal and state legislation and have been supported for many years to promote the development of the science of agriculture. These experiment tations are e-tablished in every state. but only a very few educational institutions have established engineering experiment stations, and most of these have had serious trouble to maintain a meager existence. Why research in engineering has not been more fully developed is most difficult to understand. Undoubtedly our great natural resources have lulled us into the belief that it was not necessary to use them with the economy which ought to follow proper research: ret this certainly cannot be the only reason, when we consider the tremendons fertility of the lands which have been ours for the taking: and yet we find a widespread and persistent extension of agricultural research in the states where there has been no engineering researeh dereloped.

I an fully eonvined that engineers have been so busy with the day's work that they have not insisted nuon the development of an adequate engineering research until the fact was accomplished, and that this reason is, to a greater degree than any other, responsible for the failure of engineers up to this time to secure that degree of recognition justified. Very hopeful indications now exist that this recognition is coming slowly but surely: and without doubt the motivating reason behind this changing attitude of the public toward the engineer is the greater interest, activity and insistence of the engineers in the establishment and conduct of engineering research.

You will find in this statement no striving for effect, no unfriendly criticism, but rather an expression of the deepest concern that the great needs and great opportunitios for research that are presented shall receive full recognition from the engineer. And what is true of the necessities and fruitful potentialities in the field of engineering research is equally true in that of other professions; for example. the economist, who is concerned with the economic and social development of this nation. 
Consider the highway transport field. The civil, the mechanical, the antomotive, the tran-portation engineer, the conomist. and the chemist-all hare presented to them broad opportunities for direct researeh, while, although more indirectly and perhaps somewhat more removed in time, there are other professions that may very conceivably find worthy phases for researeh endeavor.

Highway research offers two major objectives: First, the isolation and definition of each problem; and, second, the solution of the problem. These objectives are supplemental and sequential. All too frequently the first is neglected to the undoing of the second. Perhaps I may even be justified in saying that engineers have frequently in the past made grave errors, and, judging the future by the past, will continue to make grave errors in big enterprises or in the solution of big problems in one of the following ways:

a. Insufficient and inaceurate fundamental data.

b. Limitations in scope of data secured.

c. Limitations imposed by legislation or other authority.

d. The misapplication or maladjustment of data in itself correct.

Examples might be multiplied of failure or lack of obtainable suceess in engineering projects through an incorrect or inadequate analysis of the whole problem involved. More specifically, failures might be eatalogued under one of these four reasons. It might be urged that engineers are not responsille for the limitations imposed by legislation or other anthority; but are they not responsible when, as is frequently true, they eut and trim estimates and designs below safe practice to meet these limitations? More than this, it matters not what the reasons are or what handicaps exist. the engineer in charge will be held in the court of public opinion for any failures.

There are these two groups of highway researeh oljectives: First, those having for their purpose the correct analysis of each problem, and, second, those having for their purpose the finding of the remedy or the solution when the problem shall have been eorrectly isolated and analyzed. Just at this time, of the two, the first is the more important. Real progress is always slow. Consider the years of researeh required to isolate the yellow-ferer germ, and in the meantime the lives that were lost from this canse, mnknown and moliecked. The cause once known, the remedy has followed swiftly- to the everlasting eredit of the medical profession. So, too, the opportunity is offered in the highway field to do a big work now in research. Much progress has been made, but we have only started. Nor can the researeh worker stop when he shall have reached both of these objectives, for he must then insist upon the practical appli- 
cation of the solutions he finds in the field of highway transport. The most perfect solution is only valuable when applied. After all, the real objective of highway research is the most economical, in every sense of the word, and the most efficient highway transport service possible for the use of the public as a whole. The opportunities are unlimited. There is not a single phase in which there is not the necessity for major research. In the field of finance, no rational policies of providing the funds have been worked out. WT have only fairly started upon the improvements in the design of road surfaces. We need to develop better materials-cement, asphalt, aggregates, and particularly sands.

Field control of processes to insure uniformity of product is still almost untouched. Idequate provision for, and the control and regulation of, traffic must be solved. These unsolved problems, and many more, present a wide, almost unexplored, field for highway research.

Anson Marston, Dean of Engineering. Iowa State College, was unable to be present. Dr. Hatt read Dean Marston's paper on

\section{HIGHWAY RESEARCII WORK OF AMERICAN ISSOCIA- TION OF L.AND-GRANT COLTEGES}

In another report the writer of this paper is giving a summary account of engineering research at the land-grant colleges of the United States. In a word, they constitute the greatest single organized agency for engineering research in the country. The status of the land-grant colleges is especially farorable for organized highway research conforming to a national program, such as that of the Advisory Board on IHighway Research.

a. The land-grant colleges are the only nationally endowed and supported educational institutions of higher learning in the country. Hence, each of these land-grant colleges should cooperate with the National Gorernment in its highway research (conducted by the Bureau of Public Roads) and with the Advisory Board on Highway Research, itself (through the National Research Council) a ereation of the National Government.

b. Each of these land-grant colleges also is officially established and supported ly the government of the state in which it is situated. Hence, it is especially fitting that the landgrant college in each state should cooperate officially and systematically with the State Highway Commission in the same state, since they constitute two branches of the state government. 
Furthermore, the lame-grant colleges ans by organic law deroted to edueation an I resench in the industries, induding especially agriculture and mod hanie arts. No line of researeh, therefore, eould he more fittingly dereloped at each land-grant college than highway research. The planning. the eonstruction and the maintenance of good roads, their twe and the economies of highway transportation have the most vital relation to agriculture and to every hranch of mechanie arts; in fact, to every line of work for which the land-grant rolleges wo.... established.

Under these conditions it is not surprising that the land-grant colleges. without any particular organized effort, alleady have engalged extensively in highway researeh. It alpears that in 29 of the ts states highway lorituch has been undertaken at the land-grant colleges. In sone states, as notably in Illinois, Indiana, lowa, Kansas, Maine. Maryland. Minnesota and Wisconsin, a large number of highway rearch projects are in active progress at each institution.

ILwever, the highway researeh molertaken so far by the landgrant colleges is not yet so extensive or at effective as it might be, because of lack of effectively organized cooperation with each other and with the Adrisory Board on Highway liesearch. The Association of Land-Grant Colleges maintains a Standing Committee on Engineering Experinent Stations. which publishes quarterly the "Engineering Experiment Station Record," distributed to each of the land-grant colleges, giving definite and comprehensive aceounts every three monthe of the engineering reseatrehes in progress at all land-grant eolleges. Lpon the intiative of this Engineering Experiment Station Committee, the Association of Land-Grant Colleges is now a constituent organization of the Advisory Board on Highway liesearch, with a personal representative ols the board. The writer, as such representative, herehy offers the ansistance of the Astociation of Iand-(irant Colleges in pronoting high way researeh in the landgarant colleges in accordance with the progran of the Arlvisory Board on Highway liewarch. I would suggest a conference of representatives of the Adrisory boald and of the J. S. Burean of Public Roads to meet with the Engineering Experinent station Committee of the Astociation of Land-(idant Colleges.

It should be the part of the Advisery Bond on Mighway Researeh to suggest definite lines of researeh in which eateh of the land-grant colleges might engage. These suggertions should be specifie rather than general, and should bo bated partly upon the resources at the 
various land-grant colleges and partly upon the local needs of the several states.

Each of the lant-grant colleges in its highway research should establish rery close relations with the U. S. Bureau of Public Roads, and most friendly and active relations with the state highway commission in the same state.

Finally, I should say that in my judgment the character of highway research which should be undertaken ly the land-grant colleges should be fundamental and theoretical, rather than purely practical in character. For example, I believe that the testing of road materials, to determine their acceptance or rejection, in general should fall to the state highway commissions.

Inother extremely important function of the land-grant colleges in highway research should be to train the research men. The writer believes that a census of highway rescarch men in the United States would show an extremely large preportion who have been trained at land-grant colleges.

Dr. J. G. McKay, Chairman, presented the

REPORT OF COMMITTEE NO. 6, ON HIGHWAY FINANCE

Principles of highea! finance.-The exonomic and social advantages resulting from highway improvements are now generally accepted. The transportation of freight and passengers, the opening up of new areas for agricultural production, the savings in motorvehicle operating costs, the increased values of rural and urban lands, the lowered cost of marketing agricultural profluce. and the social influence of improved highway transportation are but a few of the many far-reaching results of an improved system of highways on our national life.

The method of raising revenue to finance highway improvements is typified by a lack of uniformity among the states, an unscientific distribution of the burden among the principal sources of revenue and a distribution marked by a lack of adherence to fundamental principles of sound public financing.

The financing of highway improvements today, as well as in the future, requires relatively fixed amounts of highway revenue each year. Highway expenditures are not irregular or periodic disbursements of public funds. The financing of a state system of highways involves a continuous expenditure and not high and low periods of disbursements. The amount of highway revenue necessary for new highway improvements decreases as a highway system as a whole approaches completion. This decrease in new construction expendi- 
tures, however, will pohably be absorlwed in the growing amomot necessary each year for maintenance, recomstruction am betterments. The yearly highway budget represents a ratively level and continuing expenditure of public funds and the methods of problueing highway revenue to meet the yearly costs must be plated on a somud financial basis which permits highway oflidals to plan construetion and maintenane of highways over a longer periond of years.

A budget system as a definite part of the highway program is essential. Under the budget system a lixed amomnt of highway revenue is necessury for the construction of a relatively fixed amount of new mileage each year, the balance of the resente being used for maintenance, reconstruction and betterments.

The sources of highway fumds.-There are six so-alled sourees of highway revenue which promise highway fund-property taxation. vehicle license fees. hond issues, gasoline taxes, ferleral aid and a miscellaneous group) surh as legislative alporopriations and income and inheritance taxes.

Today, as in the past, the taxation of property produces the largere share of highway revenur. Motor-vehich license fees, the second main source of highway funds, are becoming of increasing importance. The practice of pledging rehich liedne foes to meet the prineipal and interest of highway bond is-nes embungers the somece of highway maintenance funds and usually results in diverting eonstruction funds to maintenance. The third main somre of highway revenue is from the sale of highway honds. Jighway bonds alle eredit instruments sold to make highway fumb immediately arailalsle and are not in themsolves a somere of highway revenue. Real property taxation and rehicle license fees. when plerlged to meet thr prineipal and interest of highway bonds, are the true somres of funds obtained through the sale of bomks. The fourth methor of raising funds, gasoline taxation, is now heing used as a solres of revenue by a comsiterable number of states and its importance is steadily increasing. Federal aid is a fifth source of highway fumb. The sixth, or miscellamenus group, is not as important as the preceding ones and produces hut a rolatively small part of the total amount of higlowy funds. The primary soluese of highway revenue, then, are a follows:

1. Property taxation.

2. Veluicle license fees.

3. Casoline taxation.

As a general rule, sates rely upon a combination of property taxation, vehicle fors, and in a number of states gatsoline taxation. to 
produce highway funds. Though the sale of highway bonds is a common practice of both state and comnty mits, it is not a legitimate source of highway lerenue. The true source of highway bond funds is that revenue which is pledged to neet the payment of the bond, principal and interest.

The principal aricism of present methols of raising highway revenue is that the per cent of the revenue raised from property and from the highway nser is not based upon the henefits received by either source of revenue from the highway improvement nor upon the ability of either source to contribute to the improvement. In those states where real property provides the larger share of highray funds, there is an unfair burden on property which does not benefit in proportion to the amount of taxation. On the other hand, it is unfair to tax the highway user beyond the actual value of the highway service rendered. Between these two extremes lies a middle ground of highway finaneing which ean produce revenue equitably from both sourees.

The second major eriticisn of molern Fighway finance methods is the use of credit in highway improvement prograns. The excessive use of state or county credit is dangerous. If a state can carry on a normal highway improvement program without resort to the sale of highway bonds, it is a sounder and less astly method of financing than state or comnty credit.

Any plan of state or county highway financing should conform as elosely as local eonditions permit to the fundamental rules which govern the raising of public revenue: (1) Distribute the burten equitably among the contributing sources according to the benefit derived from the improvement and the differences in the ability to pay for the improvement. (2) Provide a definite anomut of highway revenue yearly. This implies the higlway burlget systrm.

The highway program of a state should bo limited to the ahility of the state to carry on economically a long-time improvement program. It is econonnically nnsound to set as an objective the completion of a large yearly program of new construction as a mark of achievement. The result of this practice is to mnduly increase the demand for labor and materials above normal. which increases the per-mile cost of highway improvement. Tnfortmately, the increase in cost resulting from this practice is not confined to state limits, but reacts on the labor and material markets in adjacent states, inereasing the cost per mile of neighboring states that may be operating on a normal rearly construction program. Whenever the domand for highway labor and material exoerls the market supply, 
the available fund of highway revenue artually constructs a smaller amount of highway mileage. An excess rohme of highway construction is also reflected in an increase in the construction costs of other industries which use the same type of laloo and materials. This disturbing element in highway construction ean be largely avoided by carcully plamning the state highway improvement program extending oxer a period of years and adjusted to the yearly highway budget. Tuder a budget system the somres of revenue should produce an amount sufficient to landle normal construction, maintenance and bettrments. The highway budget should be sufficiently flexible to take adrantage of periods of low prices.

Two distinct problems are involved in discussing the finanring of highway improvements: (1) In equitable distribution of the cost of highway improvements among the several sources of highway revenue. (2) Whether or not the use of credit is necessary in financing highway improvements by the sale of bonds. The theory underlying bonding is twofold: (a) T'o make immediately arailable a large amount of revenue, and $(b)$ 'To shift a share of present improvement costs to future generations which will benefit from the improvement.

The answer to the first major problem is found largely in an analysis of the benefits accruing to the several sources of revenue from the highway improvement. The answer to the second major problem depends largely upon the ability of the present sources of revenue to provide sufficient current fumds to complete the highway system without moluly burdening the sources of revenue.

It should be empliasized that the use of eredit. which, in my judgment, is secomd in importance to the problem of equitable distribution of the costs. does not solve the problem of distributing the highway costs among the several souress of revenue. 'The same soures of reventue which finance highway improvements when eredit is not used must also provide the revenue to meet highway bonds when funcls are borrowed. It is quite often the ase that when highway bonding is utilized it is impossible to distribute the costs fairly among the normal sources of revenue, due to the fact that the providing of the somrer of funds to retire the honds may be covered hy comstitutional or legislative enactment, or that the ability to market the bonds at a fair price may dictate that only ome somee. masully real property. shall furnish the rerenue to amortize the bonds.

'The fundanental problem is to retermine in any giren state the type of financing nexesary to produce sufliciont highway revenue to earry ont a normal highway improvenuent program. 
The physical part of the highway inprovement is an asset that remains in existence over a period of years and may be called the permanent investment. The larger the amount of permanent highway inrestment in existence in a state, the less the real need for the use of credit in financing the improvements. This situation is more the case in the older states whose road systems are well defined and a considerable portion of whose highway mileage is completed. The next factor in determining whether to use present sources of revenue or to make use of credit depends upon the wealth of a state and the ability to produce highway revenue from this wealth without unduly burdening it or decreasing the revenue raised for purposes other than highway improvements.

Using the amount of basic highway investments already completed in a state and the amount of wealth arailable for revenue purposes. we may classify state highway finance into three main gromp:

(1) States in which the permanent highway investment is sulstantially completed. States of this type are the older states. with a large amount of completer highway mileage and with sufficient taxable wealth to provide a constant yearly source of funds for highway construction and maintenance work. It would appear logieal that in states within this group the use of eredit is not desirable except as an emergency measure.

(2) States in which the permanent highway investment is partially completed. The type of financing necessary in states in this group is determined largely by the ability of present taxable wealth to produce sufficient rearly highway revenue. If the sources of highway revenue can produce funds sufficient to carry out the searly highway improvement program, the use of eredit is unnecessary. It is entirely possible that states within this group may find it necessary to plan their financial program on a basis of financing from current revenue supplemented by the use of credit.

(3) States in the early stages of highway derelopment with a small percentage of completed permanent highway investment. The use of eredit as the major method of financing is esential in states in this group.

In order to justify the construction of a highway with funds raiser from the taxation of real property the benefit to the property must at least equal the burden. Both the burden and the benefit will be reflected in land values; if the benefit is the larger, land values will increase; if the burden is greater than the benefit. land values will decrease. In this way we can arrive at a maximum above which taxation of real property for highway improvements is un- 
justifiable. The hemefit to the nese of the roud wan be neasured by the amomt he is willing to pay for this wee, the maximmm heing the highest possible rate which will not result in a restriction of traffic. The benefit to the general public is much harler to measure; we meet here the difliculty which the benefit theory of general taxation has constantly encountered. It is safe to say that the benefit to the general publice after exchuling the general as well as the special benefit to the user of the road and to the land-owner, is a comparatively small part of the total benchit. One problem then resolves itself largely into the question of a just distribution between the burden on land and the burden on the highway user. The benefit to land must be determined by a study of the effeet of rarious types of highway improvenents on land values; the benefit to the user must be deterumed by a sturly of the value of the service.

someres and rependitures of highwa!l funds in four Wisconsin combies.-Before making any decision at to the justice or experliency of the methods of highway finaneing. it is necessary to make a complete sturly of the soures of highway revenue-local, comnty and state-in typical states. Most of the previons investigations have been limited to a study of the somees of state revenue for highway purposes and have discegaded the county and local expenditures for highway construction and maintenance. The following results are bated on an analysic of all somees of revenue and expenditures in fonl Misconsin comnties from 1915 to 1921. Wisconsin was selected as a state whose systen of highway financing represents a fair averace of methods of raising highway revenues in other states. Four Wisconsin counties-Dane, Outagamie, Rusk and Waukesha-were chosen for the purpose of determining the pereentage of revenue for highway purposes which is provided by ard of the several sourees of revenue. These romtios were selected as typical comnties, representing the highway develogment in different sections of the state.

Tane Connty is a well-populaterl, rich agricultural county, with mo highway homd istues. Jadison. the aiphital city of the state, is located in the erenter of this comnty.

Ontagamie fomnt! is a good agricoultural comnty. It has finaneed a large portion of the comstruction of its highway system thromgh bould issues since 1916 i.

Rask: County is located in the newer section of the state. It is a puely agricultuml county. with soil of arelage fertility, hut as yet largely undereloped. No highway bond issmes hare been made and its highways are, with the exception of the state tomk highways. laregely minntrored. 
Waukesha County lies west of the eity of Nilwankee and is a rich dairying and manufacturing county. It has floated large bond irsues during the past three rears.

To deternine the total expenditures for highways in each of the counties in which the analysis was made, it was necessary to consolidate the expenditures mate by the local units within the county, the expenditures made by the county, and the expenditures of state and federal funds within the county. The expenditures by the different governmental units have been carefully analyzed and all expenditures appearing in the records of more than one unit have been eliminated in all except the unit which actually raised the funds for highway construction or maintenance. In the local units the expenditures made by aties have been eliminated, as their expenditures are ahmost exchusively for streets rather than for highways.

The following tables show the total expenditures for highways within each county-Tables $I(\alpha)$ to $I(d)$. From these tables it is evident that the proportion of the burden of all highway expenditures which rests upon real property varies from 55 per cent to 70 per cent in the four counties. The highest proportion is found in Rusk County, a relatively undereloped comnty. while the lowest proportion is found in Waukesha County. a very rich section, both agriculturally and industrially. This variation is due largely to differences in revenue derived from the income tax. In the richer counties the income tax furnishes a larger portion of the total revrune, and, as a result, in so far as funds for highway expenditures are taken from general revenues. the ineome tax furnishes a larger portion of rerenue for highway expenditures. It will be noticed that real property taxation and "other revenue" taken together furnish almost the same proportion of revenue for highway expenditures in all eounties. the figures being as follows:

Dane County, 76.82 per cent.

Outagamie County, 79.86 per cent.

Rusk County, 81.35 per eent.

Wankesha County, 78.68 per ecnt.

A comparison of the proportions furnished by each source of revenue in any one county for the different years substantiates the conclusion that the contribution of real property varies inversely as the contribution of "other revenue." "Other Revenue," as the name indicates, is made up of all sources of revenue except the sourees listed separately in Talle 1. but the principal part of it is made up of revenue derived from the ineone tax. The other sources of revenue 


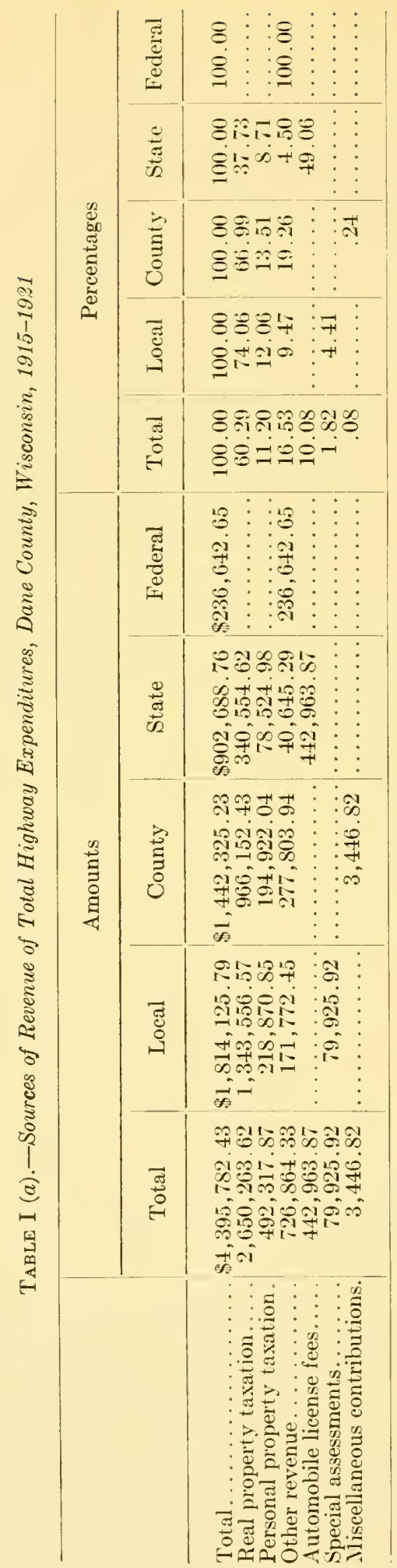

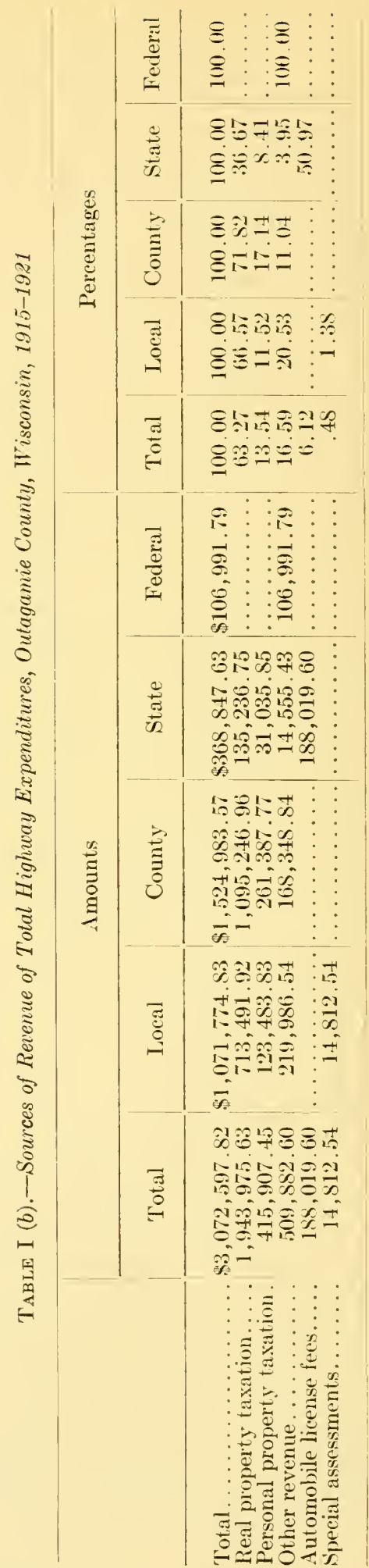




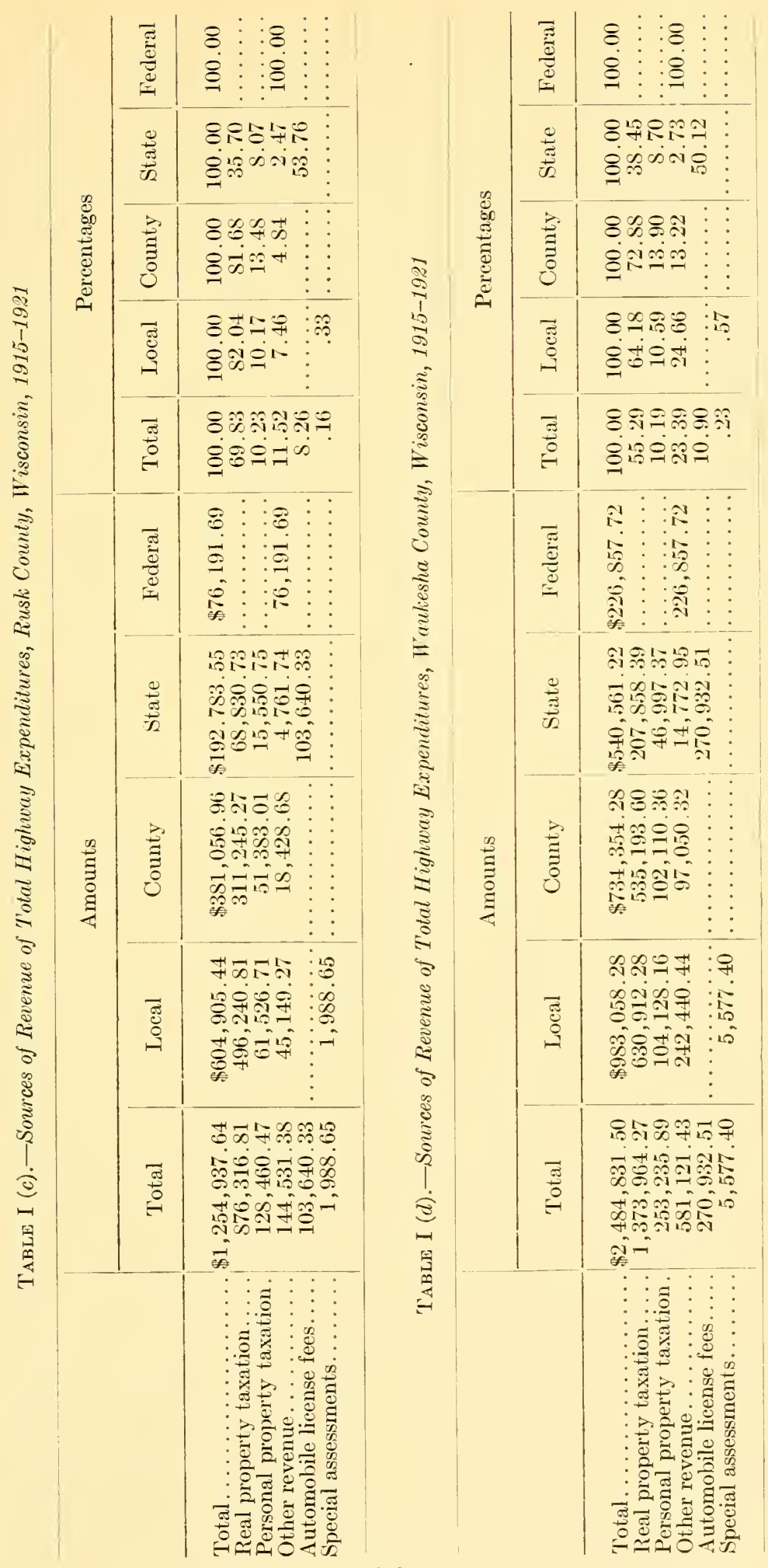


included under thi- head. such as fees, finces. etc.. form a very small proportion of the total in this elass. The annual expenditures by counties from each source of revenue show that in the vears 1917 and 1918, when the receipts from the ineme tax were highest, the proportions of revente derived from reai property taxation were maller than in the vears when the receipts from the income tax were smaller.

Table II. Percentuge of Total Rerenues for Highned!y Rerpentitures Raised by Tarions Gotermmontal inits

\begin{tabular}{|c|c|c|c|c|}
\hline County & $\begin{array}{l}\text { Local } \\
\text { funds }\end{array}$ & $\begin{array}{l}\text { 'ounty } \\
\text { funds }\end{array}$ & $\begin{array}{l}\text { State } \\
\text { funds }\end{array}$ & $\begin{array}{l}\text { Federal } \\
\text { funds }\end{array}$ \\
\hline Dane ... & 41.27 & 32.81 & 20.54 & $5 . .89$ \\
\hline Outagamie ...... & 34.88 & 49. (iis & 12.01 & 3.48 \\
\hline Rusk ....... & 48.20 & 30.37 & 15.86 & 6.07 \\
\hline Waukesha ... & 39.56 & 29.5 .5 & 21.76 & 9.13 \\
\hline Average .... & 39.92 & 36.43 & 17.89 & 5.76 \\
\hline
\end{tabular}

Table II indicates the importance of funds raised by the local units (townships and villages) for highway purposes, as compared with state and federal funds. It will be noted that the funds raised by the local units and counties furnish from 69 per cent to 84 per cent of the total highway expenditures. While this analysis is based on only four counties, it is safe to assume that these proportions are reasonably correct for the State of Wisconsin, since the counties studied were selected as representative of the various counties within the state. In other states the proportion raicel by the various govcrnmental units may vary to a considerable extent from those shown in Table II, but in those states organized on the township basis the funds raised by the local units and counties will approximate the pereentages shown in Table II. The pereentages shown in Table II are derived from the total expenditures within the different counties for the period 1915 to 1921 , inclusive. It should be noted that this period includes a few years before the period of federal airl, and also that the activity of the state in the highway field has increased greatly during the later years; so that had the period been made to include only the years 1918 to 1921 , the percentages derived from state and federal funds would probably have been larger.

Although the proportions of highway expenditures contributed by local, county, state and federal units, as indieated in Table II, may vary to a considerable extent in different localities, nevertheless the figures are conclusive evidence that any discussion of highway finance treating exclusively of state and federal expenditures omits local and county expenditures, which constitute the major portion of the total highway expenditures. While it would be advantageous 
to have more of our highways entirely financed and constructed by the state, the fact remains that at the present time local and county highway expenditures absorb the major portion of funds raised from all sources for highway improvement.

Table III. Perentage of Total Revenue for Highway Expenditures from Real Iroperty Taxation Levied by the Tarious Gorernmental Units

\begin{tabular}{|c|c|c|c|c|c|}
\hline County & $\begin{array}{c}\text { Local } \\
\text { taxation }\end{array}$ & $\begin{array}{l}\text { Counts } \\
\text { taxation }\end{array}$ & $\begin{array}{c}\text { State } \\
\text { taxation }\end{array}$ & $\begin{array}{c}\text { Federal } \\
\text { Government }\end{array}$ & Total \\
\hline Dane .. & 30.56 & 21.98 & 7.75 & $\ldots \ldots$ & 60.29 \\
\hline Outagamie ... & 23.22 & 35.64 & 4.41 & $\ldots \ldots$ & 63.27 \\
\hline Rusk & 89.54 & 24.81 & 5.48 & $\ldots \ldots$ & 69.88 \\
\hline Waukesha & 25.39 & 21.54 & 8.36 & $\ldots \ldots$ & 55.29 \\
\hline Average $\ldots \ldots \ldots \ldots$. & 25.42 & 25.94 & 6.71 & $\ldots \ldots$ & 61.07 \\
\hline
\end{tabular}

While the general property tax is the most important single souree of revenue for highway expenditures in all units-the township, the county and the state-its importance as a source of highway revenue is much greater in the township and county than in the state. As will be noted from Table III, real property taxation by the local units furnishes from 23 per cent to 39 per cent of all highway expenditures, and county real property taxation provides from 21 per cent to 35 per cent of the total highway expenditures, while state real property taxation provides only from 4 per cent to 8 per cent of the total highway expenditures.

TABle IV. Percentuge of Real Property Revenue for Highway Expenditures Levied by the Tarious Governmental Units

\begin{tabular}{|c|c|c|c|}
\hline County & Local & County & State \\
\hline llane .... & 50.70 & 36.45 & 12.85 \\
\hline Outagamie & 36.70 & 56.33 & 6.97 \\
\hline Rusk .... & 56.62 & 35.52 & 7.86 \\
\hline Waukesha & 45.93 & 38.95 & 15.12 \\
\hline Average & 46.54 & 42.47 & 10.9 \\
\hline
\end{tabular}

Table IV shows the proportion of real property taxation revenues for highway expenditures raised in each county by the various units. An arerage of 46.54 per cent is raised by local units, 42.47 per cent by county units and 10.99 per cent by the state. The real property revenue for highway expenditures raised by the state in comparison with local and county real property revenues is but a small share of the total real property revenue raised for highway improvement.

Table V. Sourees of Highury Revenue for Total Highway Expenditures Source Average percentage

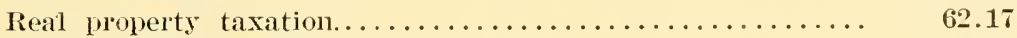

Other revenue (largely income tax funds)............. 17.01

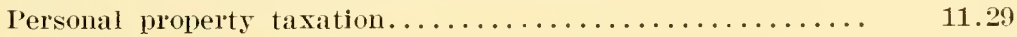

Vehicle license fees.......................... 8.84

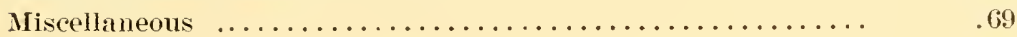


It is to be noter that real property taxation produces seren times as much of the total highway revenue as that derived from motor vehicle license fees, while the taxation of incomes (other revenue) produces approximately double the amount raised by vehicle license fees. Since local funds are cxpender on purely local roads, it is fair to compare the amount of comnty and state real property tax funds produced for expenditures on state and county highways with the amount raised by rehicle license fees used on the same highways. County and state real property taxation produce 32.65 per cent of total highway levenue, vehicle license fees $\$ .84$ per cent. Real property, which contributes 61 per cent of all highway expenditures, produces for county and state highways four times as much of the total expenditures as that produced from rehicle license fees.

Conclusions Based on Analysis of the Sources and Expenditure of Highway Funds in Four Representative Irisconsin Counties:

1. The major portion of the total of highway funds in Wisconsin during the seren-ycar period from 1915-1921 was raised by township and connty mits rather than by the state.

2. Real property taxation was the chicf source of highway revenue, producing an average of 61.07 per cent of the total local, county and state highway expenditures.

3. Vehicle license fees produce 8.84 per cent of the total highway expenditures.

4. Real property taxation for highway purposes bears too large a portion of the burden of highway expenditures, producing from 55 per cent to 70 per cent of the total highway revenue.

5. The major portion of the burden on real property is due to local and county taxation of real property for highway purposes. The local units produce 46.54 per cent; county units, 42.47 per cent; and the state, 10.99 per cent of the real property revenue for highway expenditures.

6. Real property contributes a larger share of highway revenue during periods of depression, when the revenue from other somecs decreases. 'This results in an excessive levy on real-property owners, since the tax levy on real property is paid from income derived from the property, and in periods of low prices this income is reduced at least as much as income from other sources. 
7. When income-tax funds increase within a county, real property taxation for highway purposes decreases.

8. As a county develops and grows richer, the relative burden on real property for highway purposes decreases. When a county or state is in the developmental stage, the cost of the permanent features of highway improvements can be economically financed by issuing a limited number of deferred serial highway bonds. By this method the burden on property is lightened during the early years of the improvement, increasing with the ability of property to produce more revenue as a result of the highway improvements.

9. A reduction or elimination of state taxation of real property for highway purposes in Wisconsin would not materially reduce the total of real property taxation for all highway purposes.

10. Reduction of real property taxation for highway purposes in Wisconsin would result largely in a reduction of local and county taxation of real property for township and county highway expenditures.

The problem of reducing real property taxation for highway improvements. - The two logical sources of highway revenue are real property taxation and vehicle license and gasoline taxation. When real property taxation produces too large a share of highway revenue in comparison with the share produeed by rehicle license and gasoline taxation there are three courses which may be followed:

1. The elimination of inefficiency and waste in the expenditure of highway funds by the local and county units. Eighty-nine and three-tenths per cent of all real property tax funds for highway expenditures are raised by the local and county units. Any reduction in expenditures by eliminating the waste of highway funds will result in a reduction of the burden on real property for highway expenditures. This may be accomplished as follows: (1) Provide for strict supervision by the State Highway Department over the construction and maintenance of purely county highways. (2) Provide for close supervision by the county units orer township highway expenditures, possibly limiting the maximum expenditures by the local units for highway expenditures to a fixed percentage of the township property valuation.

2. A reduction in the total yearly highway expenditures-township, county and state.

It is obvious that the present county and state expenditures for 
highway improvements lags behind the need for improved highways and is not a desirable solution of the problem.

3. Shift part of the burden of highway improvements from real property to other souress of revenue.

By substituting other sonrees of revenue for a portion of the real property revenue, we cannot decrease the total revenue raised by the varions units necessary for purposes other than highway improvement. A reduction in the amount of highway improvenent revenue raised from the taxation of real property without raising a like amount from some other source of resenne would result in a reduetion of the total highway funds below a neessary minimum. The logical solution is to increase the total revenue raised from old or to create new sourees of revenue for highway improvement to replace the revenue lost by the lowered taxation of real property. The source of this increased revenue is the highway user, whose demand for highway service is largely responsible for highway improvements.

Charles M. Upham, State Highway Engineer of North Carolina. gave an illustrated discussion on

\section{RESEARCH PROGRAM OF THE NORTH CAROLINA STATE IHIGIINA COMMISSION}

The immediate necessity in resarch work is the practical applieation of our present knowledge already olutained by rescareh. We now have vast funds of knowledge that have been obtained through researeh, but the benefits obtained by the present knowledge have not been developed to an extent commensurate with the labor and money expended. The reason for this is the non-applieation of the knowledge already supplied. Therefore, on problem is not necessarily a problem of research alone. but also a problem of alplication.

l'robably there is nothing new in the fact that North Carolina has a research program, becance every state, comnty or municipality that is carrying on the construction of highways has, to some degree, at least, a researeh progran. In addition to this, lahoratories seattered throughout the United States are also earrying on various researches. A survey by the Highway Reveareh Committee dischesed the fact that many liundreds of projects are in operation. Some of them. of conrse, were duplicates, but the fact was disclosed that a great anomut of research is being carried on.

The difficulties of a rescareh progran are numerons, but probably no more important problem exists than that of keeping reseatred within practical limits and carrying it on in such a manner that when completed it may have a practical application mol serve as a 
step in working out economically some of the highway problems. Already a vast amount of research knowledge has been acquired, and this information is written into bulletins and distributed; but, unfortunately, many times the bulletins are of little practical value, because they do not reach the proper persons, nor are they written in a manner that will serve the busy official who generally organizes programs. Our research problens are still unsolved because the important step-the application of highway research work- has not been accomplished.

The problem of research secms to divide itself into two minor problems-research of the problem itself and the application of the research results. The application of the results obtained is such an important step that it could almost be considered a research problem in itself, and a proper study of this application would be well worth while. We find that a great amount of research has becn carried on, but as ret a vast anount of the knowledge gained has not been applied to road-building, and consequently the economical value of the research has been lost.

In North Carolina every attempt has been made immediately to apply the results of research. Almost every step in construction is being studied in detail, and when anything of value is discovered it is immediately applied to construction on a large scale.

Not only does rescarch include problems that may be carried on by the laboratory, but it includes transportation problems, problems that will ultimately render road service to the user of the highway. The great research problem is to render road service to the public so that transportation may be more economically carried on. These major problems of transportation and road service are, of course, influenced by other problems, such as the problems of eonstruction, maintenance and operation. In all highway research there should be constantly kept in mind the question of how the results of this rescarch can influence the road service rendered to the user of the highway.

Sand asphalt pavement.-One research that has recently been earried on has been the development of progressive type roads. Certain localitics in North Carolina furnish practically no road-building material, with the exception of sand. The problem in this instance was to devise some means wherely these large quantities of sand could be used in road construction. The answer came in the construction of the sand asphalt road, which is made up of approximately $S S$ per cent sand and 12 per cent asphalt. These roads may be constructed in either single or double track, according to the needs of the traffic, and are generally construeted $4 \mathrm{r} / 2$ inches in depth. This method of construction affords a moderately low cost road, which 
renders very satisfactory road service to the locality. It is not expected that this type of road will stand up under a large amount of heavy truek traflie, but it is a development road and is satisfactorily rendering road service to the user of the highway. Though this type of road is, of eourse, the result of laboratory research, it is more particularly the result of the proper application of laboratory researeh.

Marl rock base. - Inother loeality in North Carolina furnishes no stone for road aggregate, but it does have an underlying strata of marl rock, the result of a large deposit of sholls. Although at some time this deposit must have been on the seashore, at the present time it lies some $S$ or 10 miles back from the ocean and about 4 or 5 feet underneath a swamp. This marl rock is boing quarried and crushed and is furnishing an excellent base for a sand asphalt surface. While the details of this construction were taken from earlier road work, still the use of this marl rock means the practical application of inrestigative researeh.

Subgrades.-The studies of subgrades have been demanding eonsiderable attention during the past few years, but there scems, even at this time, to be a lack of proper application of the findings. It has already been determined that different soils are affeeted differently by the varying amounts of moisture. In some eases, however, no attempt is made to select the best soils for subgrade purposes. In many localities a proper selection of soils will not only furnish an ideal subgrade, but will serve as a road, a sulgrade highway, to take traffic up to as high as 400 vehieles a day. These seleeted soil roads may be maintained for a period and then used as an excellent subgrade for the next better step in construction.

Capillarity.-Recent researeh has brought to light eonsiderable information regarding the capillarity of different soils. For a long period it seemed as though a poor subgrade or a elay condition might be best remedied by the eonstruetion of a 'Telford foundation. Now it appears that the Telford foundation served as a drain to carry away the free water, but was of little, if any, value in taking eare of the eapillary moisture. Recent experiments have shown that a layer of material similar to sand is more effeetive as a means of eutting off eapillary moisture. This explains why exeellent results have been obtained in the construetion of macadam roads on clay subgrades when sereenings have been spread on the subgrade. It also explains the exeellent results obtained with bituminous roads construeted on a gravel and sand foundation.

Research has shown that eapillary moisture in the subgrade is not eut off from the overlying road surface as effieiently by coarse material as it is by ordinary sand. The reason probably is that the 
subgrade material finds its way into the interstices of the coarse material and the eapillary tubes of the subgrarle material continue to act through the interstices of this coarse material; whereas, in the case of the sandy material, the subgrade material of high eapillarity is exchuled, and therefore the capillary artion of the sand in not so great. This is an important point and one that can be taken adrantage of and easily and economically alpliced to road work on a large scale much more so than is commonly done.

Teneer surface. - Another important application of research work is in the construction of stone vencer on earth roark. In the south there is an exceptionally large mileage of earth roads, consisting mainly of the sand ray. topsoil and gravel fyes. The bearing porrer of these roads is high and the strungth is gratt; yet maintaining these roads is a problem, since they offer little resistance to abrasion. Thus the problem in this particular instance is to secure some means of protecting the surface against alusion and to abate the resulting dust misance. 'The answer serms to be the stone veneed' surface in which the quality of an asphalt wearing surface is combined with the strength of an carth road. Feveral attempts have been made in applying bituminom material to arih roarls. The results. in general, have been unsucesuful because, eren though the bituminous material was sulliciently light to penetrate the surface, it had no binding power or strength whatever, and if the bituminous material was sufficiently heary to have a binding value, it would congeal on the surface and peel oft. owing to a dust mat that formed undemeath the bituminous material. With the reneer surface a layer of stone of approximately three inches in size is applied to the earth road and rolled partly into the surface, after the surfare has been searified or loosened. This veneer surface of stone is then penetrated with a bituminous material having a consisteney to give sufficient strength to hold the stone in place and afford resistance to weatr. This bituminous material is then covered with proper sized stone, is roller. and then opened to traffic. The stone is hold in place from below by the earth road and has become an integral part of it. The bitiminons material holks the stone in place on the surface and aftords resistance to traflic abrasion. Thus we lave a combination of the strength of an earth road and the wearing gualitics of an asphalt parement-another instance of the practical alplication of research work.

IIard surface types-course aggregate.-Another problen in construction is the ideal construction of harl-surfaced roads. Much laboratory research has determined that the aggregates must be of certain qualities and properly graded. Recent experiments in con- 
crete work have shown that nuch depends upon the grading of the aggregate. Although the early tests indicate that a large aggregate gives a higher strengtli value, long-time tests seem to show that the aggregates below an inch and a half give higher strength values. In this instance we have a rescarch giring one result, yet it is impossible to apply this result in its entirety, since the present arrangement of crushing plants and aggregate production machinery does not furnish economieally an aggregate that gives the highest ultimate strength. Therefore the proper applieation of this research demands a compromise approaching the ideal eonditions.

Core drill.-Considerable research is being carried on attempting to correlate the laboratory tests of materials to the final produet as found in the parement by the core drill. At the present time it seems there are so many variable factors that it is imposible to control all of them, and, as a consequence, the final product raries considerably.

Not only have studies of the coarse aggregate lieen made, but a new test for fine aggregate has been developed, which seems to permit a wider range of fine aggregate to be used, or, in other words, aggregate that would be condemned under the standard test ean now be used with safety. This test consists essentially of testing the aggregate in compression and transtersely rather than in tension, as is done in many of the present-day standards.

Investigations in cement also show that this material raries considerably, and that the final strength of the road depends primarily upon the quality of the cement used. It seems that individual brands may vary considerably. This may not be only a question of manufacture, but also one of handling and storage until the eement is used.

Surface finish.-Possibly no single demand on a parement is so great as that of impact of traffic. Impact depends entirely upon the smoothness of the roat surface; therefore ennsiderable study has been given to obtaining wmooth surfaces. This has been put into practice by devising various means of finishing the surface.

In the case of concrete, it is found that the smoothness of the surface depends upon many factors, chief among them being the consisteney of the concrete and the charicter of the sulggrade. The subgrade, after being wet by the conerete, expands or contracts and the green conerete in the road surface does the same. Various types of check templates are being used to check the surface before it sets up, so that it may be corrected while still plastic. In the ease of the bituminous roads, test-boards and straight-edges are used during construction. After the road has been opened to traffic it is again 
tested. Recently, experiments have been earried on with the vialog, an instrument derised for measuring unevenness of road surfaces.

There has been much discussion relative to the detailed construction and maintenance research problems, but probably the most pressing problem and the most immediate need is a solution of the proper methods for taking the research work that has already been done and giving it practical application. This leads us to the problem of organization and personnel; the varying results obtained in the work show the influence that personnel has on any undertaking. Research in construction and maintenance problems deals with definite quantities, but research in organization and personnel, since it deals with varying factors of the human mind, is more difficult so solve. The proper and economical application of research work still involves research in the matters of personnel and organization. It is useless to spend time, money and effort in carrying on research unless the results are applied in such a way that our highway problems will be more economically solved than they otherwise would be. In order that the facts may be used to the greatest advantage, they must be presented to the proper persons in a way that is definite, concise and easily understandable.

\section{Third Session}

The meeting was called to order at 9:30. Frislay morning.

Chairman Johmon: The Board has received a report of cooperative work being earried on in Iowa on "Inplact in IIighway Bridges," by Prof. Fuller, Chairman of the Subcommittee of the American Society of Civil Engineers on Impact in Highway Bridges. His report is upon the cooperative progran between the U. S. Bureau of Public Roads, Iowa State College, and the Engineering Experiment Station of Iowa State College. Dr. Hatt will read this report.

Dr. Hatt: Mr. Fuller's report is as follows:

Cooperative work was begun in the summer of 1922. In important item at that time was the adaptation of existing instruments or the development of new instruments for measuring drumic stresses. A number of instruments were tried out, with the result that only those best adapted to the purpose were used in 1923.

A description of the 1922 work, discussion of the rarions instruments used, and a portion of the results have been published as Bulletin No. 63 of the Engineering Experiment Station of Iowa State College. The greater portion of this bulletin was inchuded in the 1922 report of the Committee on Impact in Highway Bridges of the American Society of Civil Engineers and published in its Proceedings for Mareh, 1923. 


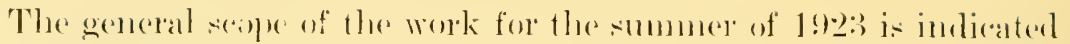
in the following:

Structures intestigated:

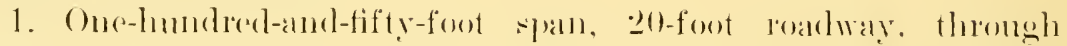
arred ahord sted truss. with concrete floor on steel stringers, known as the skunk liver Bridge, on the Lineoln llighway, located absut three-fourthe of a mile cast of Ames.

2. Thirty-three-foot sman, 20-foot roadway, consisting of concrete floor on steel stringers. This is an approach span to the main Skunk River Bridge.

3. Seventy-foot span. 24-foot roadway, through plate girder, with concrete floor on steel stringers. This is known as the Squaw Creek Bridge, on the Lincoln Highway, and is located within the eity limits of Ames.

4. Forty-foot Pony truss bridge, 1s-foot roadway, with reinforced concrete slab resting directly upon transwerse floor beams, located on comuty road near Roland. lowa, about twenty miles from Ames.

Loads:

1. Two 15-ton trucks with solid rubber tires, with about twelve tons on the rear axles and three tons on the formard axles.

2. A 10-ton Holt caterpillan tractor (on structures 1 and 2 only and only for about two hours).

Range of norli:

Floor.-Rather complete work was done on the stringers of struetures 1,2 and 3 and on the floor beans of 1,3 and 4 . This includes impact on suroth floor, orer one-inch obstructions and over tro-inch obstructions, and also distribution data for static loads which show the actual mit stresses on all of the stringers for one and for two trucks.

Trusses.- Tieadings have been taken upon the greater portions of the web nembers of structures one and four, of the chords in struetme four, and of the girdor flanges in structure three.

Time.-Field-work was started on July 1 and ended September 15.

\section{Instinments:}

1. Three Tmmeane reoreling extensometers.

2. Five West direct rarling extensonteters.

3. One photographic mimor reording extensoneter developed by the $T^{\top}$. S. Burean of Publie Roads: avalable after August 1. 
4. Six clectrical remote reading and recording strain gages, in which records of all six instruments are photographed on one roll of paper-developed by U. S. Bureau of Standards and made available for one week in september through courtesy of that Bureaul.

\section{Calibration of instruments:}

Before the field-work was begun the instruments were calibrated for static stresses. No suitable equipment was then araibable for dynamic calibrations. Two more or less impromptu devices have since been developed which have given, within reasonable limits. positive as well as comparative calibrations under rapidly changing conditions. These have been, first, an impact machine in which a weight was dropled upon a tension bar to which the instruments wore attached; and, scond, a vibrating devios which produced known ehanges in length in very short but known inerements of time. The work of alibration, while ret not romplete, las been carried far enough to insure a reasonably accurate interpretation of results. which will be compriled as soon as practicable.

Chaiman Geo. E. Hamlin presented the

\section{REPOR'T OF COMMITTEE NEMBER 4, ON HIGHWA I TRIFFIC INIIISIS}

1)uring the year many states have carried on. to a greater or less extent, highway traflic censuses. Attached to this report is an amalysis of the characteristies of such surveys. with data obtained. The detailing of this data shows that the various states realize the importance and value of traffic information and are cach year increasing the census records to specify adrlitional information of movement, conmodity and length of haul.

In this connection, the chairman wishes to call particular attention to Prof. Blanchard's recommendation, that this eommittee strongly differentiate between a highway traftic census and a highway transport survey. 'The traftic census will give information pertaining to the traftie using the highway at the time the consus is taken; the purpose of the highway transport survey is to determine the probable anount and character of the future traftic which will use a given highway during the lives of its sevelal component parts. Up to the present time, the information collected by the various states has given trattic census information, but as far as the ehaiman has been able to determine, no state has extensively taken up the highway transport survey. 
I highway traffic census is of value only for determining conditions which exist at the time the census is taken. It may be that by the construction of a new scction of road the general trend of traffic may be radically changed in any particular locality. After an extended highway traffic census, it is recommended that additional counts be taken at critical periods of the year in succeding years, from which, after a number of counts have been taken, curves of natural increase can be plotted from which in turn an estimate of increased traffic for a reasonable period of years can be roughly determined. This estimate should also include the curve of increase of motor vehicle registration which can be determined at the present time in every state. It is questionable if such a curve can be applied to other than the locality in which it is developed. In fact, even in a state of small area, different curves will have to be developed for different sections of the state, rather than to utilize a general curve for all of the main highways. Up to the present time, it has been found impracticable, with the data available, to develop a formula of this character.

The value of an extended traffic survey in determining the allocation of construction and maintenance funds in the development of a highway system is unquestioned. Such traffic survey, however, should be utilized for type and strength of surface rather than for location of expenditures, inasmuch as the derelopment of new territory within a state is as much a demand upon the expenditure of highway funds as is the taking care of traffic already developed. This point cannot be stressed too strongly, for, if the allocation of funds depends wholly upon the volume of traffic, only a few of the roads in any particular state would ever receive a construction allotment. This is where the decision of the engineer in charge is valuable, and this decision must be based on potential as well as present traffic conditions. In other words, he must minimize any particular locality to consider the value of transportation in the whole state, and each construction unit must be based on his vision of the value of such unit.

To carry out a traffic survey successully, much plamning must be done preliminary to the actual field-work. Stations must be chosen which will give the arerage condition along each highway, and these must be located at a sufficient distance from the congested centers to eliminate as far as possible the strictly local traffic which will not enter into the construction program. Care should also be taken to establish stations where traffic is divided, so that the value of each section as well as each road may be determined. Each station should be occupied at least one day each month, for an eight to twelve-hour 
period. This should be arranged so that the same station will be oceupied successively on different days of the week, and on a different hourly basis, to detexmine daily as well as seasonal variation of traffic. Blank forms where check-marks may be used will reduce the time required for gaining information and names of cities; character of loading and make of truck or car may be coded, thus simplifying the actual compilation of the records in the office.

The personnel require a certain amount of special training, although courtesy has been found to be the largest asset. "A special sign at the census station giving the reason for the questioning is the greatest factor in reducing the time required to pass a car or truck through the station. The enumerator can check many of the questions on the card by observation - the number of questions asked the driver in the case of the pleasure car covering only origin, destination and business or pleasure use. In the truck census other necessary information will require a longer period and larger party, where weights are actually taken on a platform scale installed for this purpose. A platform pit type seale of 25 -ton capacity can be installed, with automatic dial and the necessary covering house, for $\$ 2,500$ to $\$ 2,800$.

The chief of surrey should be thoroughly aequainted with the entire district, both in regard to road and traffic conditions, and be able to detect any seeming discrepancy in the records sent in. Abnormal conditions due to a particular event, such as a football game, must be previously discounted, so as not to congest traffic on that day, even if the stopping of the cars for questioning is omitted. Each party may consist of from three to six men, the number varying with the importance of the station occupied, each party having a designated head, who reports to the chief of survey and under whose direction the party operates.

In the State of Connecticut the cost of three parties operating over a year's period with varying numbers, including necessary automobile transportation, board allowance, etc., has been about $\$ 27,000$.

It will not be a function of this report to determine results obtained from the Connecticut traffic census, which are being compiled and tabulated under the direction of J. G. McKay in the U. S. Bureau of Public Roads. The survey was carried on for a full year, ending in September, 1923, with 56 stations and operated by three parties. The tabulation is still in progress and the full report is being prepared, so that the entire cost cannot be given at this time. It is, however, believed that the tabulation cost, including the printing of the reports, will not exceed $\$ 10,000$.

Dean Johnson. of this committee, in addition to continuing the 
traffic count of the Marrland highway system, from which a revised traffic map of the state will be compiled, has, in cooperation with the U. S. Bureau of Public Roads, established an experimental traflic counting station where weights and numbers of rehicles are antomatically recorded. This installaton was in operation for two months during the late summer, but progress was not made past the experimental stage, and in september lhe apparatus was remored for changes Dean . Johnson notes, in eommenting mon this work, that there is "sufficient promice of results to make it worth while to spend considerable more time experinenting."

1 self-reeording device of this kind, which an be installed and operated at minimmu cost, should solve, to a large extent, the objection in many localities to the expense of a traftic censur for a period of time sufficiently long to obtain acemate results.

The committer believes that, while a traffic count is of value, more details should be eomsidered than has been customary in the past. so that an analysis of present and probable futme traffic may be made, as stated in a previons faragraph. This eemsus must include enough detail and be taken over an extended enongh period of time to detelmine the seasonal traftic, which varies greatly in certain parts of the romutry and whieh is a maintenanee rather than a construetion problem. The eonstuetion type must be based on the heaviest travel rather than on arelage or seasonal travel. A determination should also inchude the offeet of slow-moving vehicles upon the general situation and the ennsideration of the possibility of legislation which will remove such vohicles 10 socondary roads during high peaks of traflic. This may inchude a recommendation for legislative act to govern the minimum speed permitted mpon class A roads during eertain hows of the day or times of the year. It is believed that the slow-moving rehicle is often the canse of congestion upon a main highway, that the importance of this fate is not at the present time

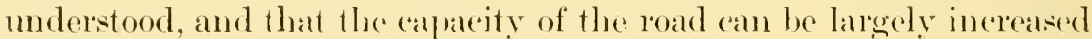
hy restrictive regulation.

Mr. Hamlin: Mithout question, the design of roal must eorer peak eonditions rather than average comditions. Probably the most abormal eonditions wo lave in Comneetient are during the football games at New Haren. Two yeals ago we took a censts of vehieles at the Yale-Princeton gane. Usually ahout 7T,000 people attend the

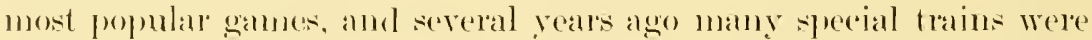
l'um. There may have been special trains at the Yale- lrme wame this year: but, if so, they were not extensively adrestised. Quite a number of people eomm the night before, stay at New Haven, and go back the serond day; so this figure does not represent the entire 
traftic. Two years ago we took a census from $8: 00$ a. m. to $8: 00$ p. m. It that time there were comnted 26,016 ars on seren different roads which eover, to a large extent, the highways into New Haven. 'This year there were eounted for the Tale-1rmy game 35,981, or approximately a 3,000 average per hour. The maximum reeorded traftic for one hour, at Station 5 , on the Derby Road, was 1,393 rehicles between 6 and 7 p. m., or 23 vehiches per minute-more than one rehicle every three seconds. At Station jo the mimum passengerear traffic was 1.385 , showing that out of 1,393 cals only eight were other than passenger motor ears. The figures show an increase of abont 40 per cent in all traffie in two years attending one of the major games. This is one of the conditions to be met on the boston Post lioad. The are building a 24 -foot highway of 10 -inch eoncrete. with shoulders varying from 8 to 10 feet-the maximum shoulder we ean obtain. The plans for the future commerend the eonstruetion of 36 feet of concrote, or form : $)$-foot travel paths, giving two lines of travel in both directions.

In the material reopived at the eommitters request form the various states, there was a detailed report from the State of New Jerser. Mr. Sloan, of Now Jersey. has derchoped a factor of 12.2 as representing the relation betwen the maximsm daily amb houly travel. I have been unable to check this fatetor with the results we have obtained in Comnecticut. but. loughly, he estimates that the maximmm of travel on any road is domble the average hourly travel. I would be interested if any of you can cherk these eonehnsions. In regard to foreign ears. the arerage of 14 traflic stations extending to all parts of the state show a percentage of forcign ears of 20.8 . He has statistics regarding draw-bridges and he draws onne very interesting conchusions in regard to the value of lost time to vehienlar traffie due to their opening. Aceording to $\mathrm{M}_{\mathrm{r}}$. Sloan, the number of licenses will depend on growth in population, and within the next deade will reach a saturation point at abont one vehicle for each four persons. By 1950 the popmlation of the state will have inereased not quite 50 per eent over that of 1920 . By 1950 it is expected that the number of licenses will be 2.7 times that of the present year. It eannot be assumed. however. that highway traffic will inerease in direct proportion to the number of licensed motor rehieles. It has been found that traffic has increased in New Jersey as the square root of the inerease in the number of licenses. Assuming that licenses will increase 2.7 times, it is seen that highway traffie will increase slightly more than 1.j times.

Dean A. N. Johnson: The results of the Maryland traffic rensus 
were compiled too late to forward to Mr. Hamlin and are now presented.

The State Roads Commission of Maryland has conducted a traffic eensus, the results of which now cover six complete years, 1917 to 1922, inelusive. The counts were taken at approximately 200 stations throughout the state highway system. The mileage to which the traffie counts apply is approximately 1,600 miles. The counts

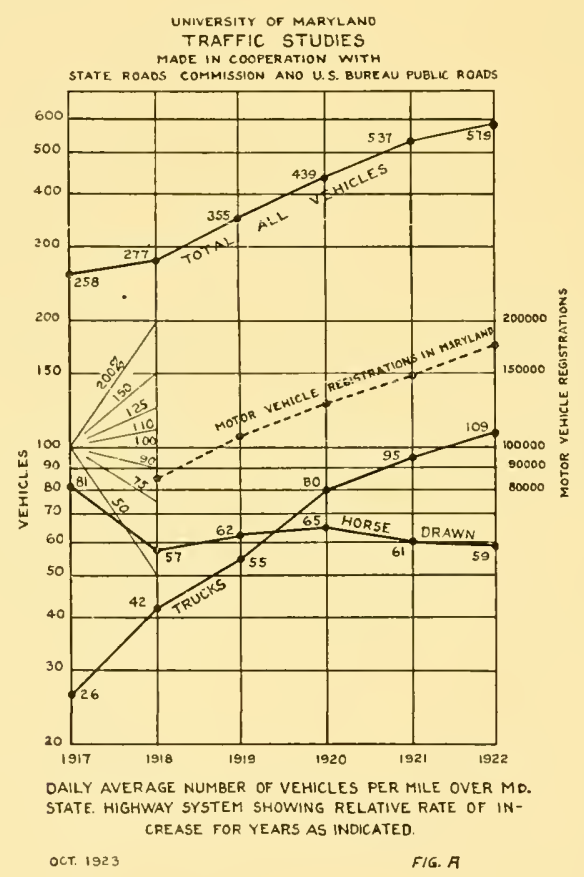

were taken at the same stations during the six-year period, one day per month, on different days of the week. The results are best seen by reference to Figure "A."

First, attention is called to the increase in the average daily number of vehieles per mile over the state highway system-from 258 vehicles in 1917 to 579 vehieles in 1922 . It is noticed, however, that the rate of increase is flattening (the diagrams being drawn to semilogarithmic platting, the slopes of the lines indicate the true relative rate of increase). Whereas the rate of increase for the period 1918 to 1921 is approximately 25 per cent, from 1921 to 1922 it is but little over 10 per cent. It is of interest to compare this rate of increase with the rate of increase of motor vehiele registration, shown by the dotted line. It is seen that for the four years the increase in motor vehicle registration is nearly constant (about 20 per cent per 
year), and that the rate of increase in total traffic has lessened somewhat in advance of what we may expect for motor vehicle registration. Both of these curves, it would be expected, ultimately would follow closely the population curve.

The traffic counts show the number of horse-drawn vehicles and the number of trucks. It is to be noted that the amount of horsedrawn traffic has varied but little in the past five years, being almost constant in amount, while the rate of increase in truck traffic has been rapid, averaging for four years, 1917 to 1920, nearly 50 per cent a year. The curve then shows a somewhat marked lessening of
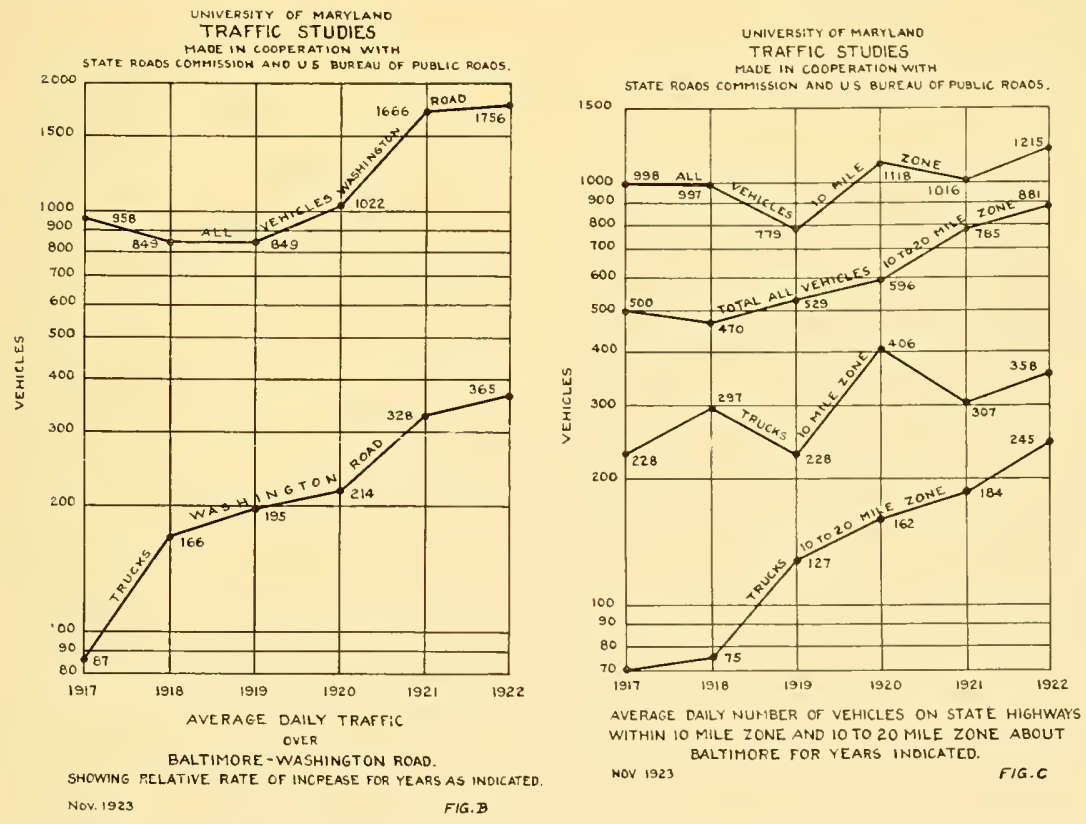

the rate for 1920 to 1922 , inclusive, being for this period about 20 per cent, indicating that we may expect the rate of increase in truck traffic to be somewhat greater than the average for all traffic.

Attention is called to Figures B and C. Figure "B" shows the curre of increase of traffic on the Washington-Baltimore Road for the entire distance between these points, about 40 miles. The amount of traffic on this road decreased somewhat from 1917 to 1918, remaining about constant until 1919, when from this time to 1921 there is a marked increase in traffic, approximately 50 per cent per year, which has fallen off sharply in 1922 , the rate of increase from 1921 to 1922 being nearly in accord with that for the average traffic over the entire state highway system. 
The incorase of truek trattic over the Washimgtom-Baltimore lioad is markedly different from that for the average traffic. Whereas the total taffice from 1917 to 1918 foll oft' arer 10 jer rent, the truck traffic increased alout 100 per cent. and has continued to increase at a sonewhat less rate throughout the entire period from 1917 to 1922. inclusive. but showing, in acourd with the rate of incrase for the traftic as a whole, a tistinct lesening for 192.2.

Figure "C" shows the rate of inclease of all traftic, as well as trucks for the first ten-mile zone about baltimore and the second tenmile zone. The emres for the ten-mile zone for all traflie and for the truck traftic show a marked (lrop) during the period 1918 to 1919. This probably does not reflect the true traftic conditions. owing to the fact that on ecotain traffic stations within this alea enomts were not made on all of them for the year 1919: and, while there may have been some decrease in the traffice it is doubtful if it was as narked as has been indicated.

In general, it is to be observed that there has hede a somewhat greater increase in the anmomt of trattice in the serond tem-nild zome as compared with the lirst ten-mile zone.

From a study of these reeorels, it would secum that we are now able to forecast somewhat elosely the trattic. as a whole, that the state highways of Maryland will be called upon to carry for a number of years hence, as it is evident that the rate of increase must ultimately conform to the population eurve, which has an inclease, perhaps, of 1 or 2 per cent a year. As the present traftic increase is somewhat in excess of 10 per wont a year, for a few years hener the incereas. will continue ammewhat nore rapidly than that for the population.

The results, as here developed from the traffic census on state highways of Maryland, it is seen, coincide very rlosely with the results as pointed ont by Mr. Hamlin from the New Jersey reports on traffic conditions, so that we nay expert, in most well-settled commumities, to find om traftic conditions approalding, within a very fow years, more nealy the normal and fixed rates of increare, comprababs with that of population.

Mr. Dochastel: I remember soring a ferw wooks ago, in Qumbere,

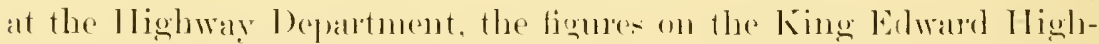

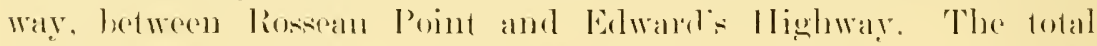

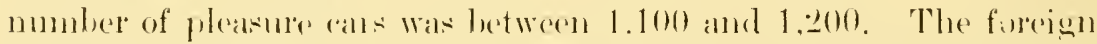

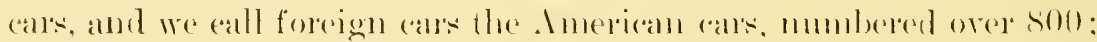

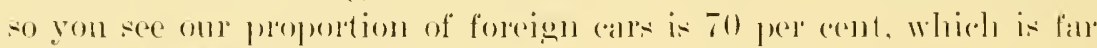
more than Mr. I Iamlin's connt.

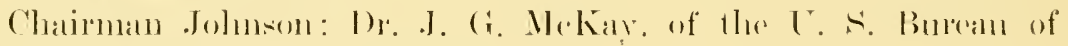
Public Roads, will give a talk on 


\section{ANALYSES OF MOTOR TRINSPORT IN NEW ENGLAND}

Three groups of agencies in New England are engaged in the transportation of people and commodities-steam and electric rail lines, boat hines, and highway transportation eompanies. The ultimate purpose of each agency is to produce the highest type of coordinated transportation service for New England producers and consumers.

The highway as an ageney for the mass movement of people and commodities is a modern development of transportation. From September to December. 192.2. orer a million net tons of freight were transported by motor trucks orel the Connecticut Highway system. Rail service during this preriod was below par. owing to labor difficulties. and naturally this situation increased the rohme of hiohway transportation abore the normal level. The largest portion of motor truck net tonnage morement was limited to the short-hanl zone: 67.4 per cent was hauled les than 30 miles. 18.4 per cent from 30 to 69 miles, and 14.2 per cent over 70 miles.

Two factors are in general responsible for the highwy transporting of commodities orer 29 miles: (1) Raypd and efticient rail service for enabling shippers to obtain fast rail transportation of 1. C. L. freight is lacking. (2) 1 limited number of commodities are especially adapted to motor-truck shipment and will probably continue to be shipped by truck for distances heyoud the short-hanl zone. The total ton volume of these commontities is not very significant.

Since January, 192:), the per cent of the total net tonnage transported by motor truck beyond :30 miles has decreased, indicating that. with eflicient rail anct boat service. the motor truck is not a major transportation factor in the middle-distance and long-haul zone in Tew Fingland.

The commodities transported by motor trucks on the Connecticut highways reflect the industrial production of New England. Of the total net tomnage, 79.6 per cent are manufactured goods. 8.5 per cent products of agriculture, 7.1 per cent products of animals, 6.7 per cent products of mines and t.1 prer cent produets of forests. The large per cent of mamufactured goods is partly explained by the fact that more profit ean be made in motor-truck trancportation of goods of this character than by moving bulky goods of lower value.

Of the 240 motor trucking eompanies investigated in the principal cities in New England, the majority operate with a small fleet of trucks and serve a limited territory. The number of large. wellorganized and efficiently-operated companies is small. 
Motor-truek transportation in New Fugland is loosely organized, keenly competitive, and operated larely on a contract basis, with rapid fluctuation in rates. I gradual growtl of larger motor trucking companies is dereloping. which is escential to stability of service. It is entirely probable that. with the development of governmental regulation of motor-truck transportation and the resulting stabilization of the motor-truck rate structure and publication of lates. the majority of motor trucking rompanies operating in New Fngland will discontinne the contract system of rate-making. Motor-truck operators, according to their own statements, will weleome regulation which will insure stability of rates and eliminate cut-throat competition.

The relatively high percentage of failure of smaller motor trucking companies indicates the narrow margin of profit in the motortrucking business as it is now being operated in New England.

In general, New England manufacturers ship their commodities by motor trucks for two reasons: (1) prompt and reliable service; (2) trade demands.

Railroad freight congestion and rail embargoes force mannfacturers to ship their products by motor trucks in both the short- and long-haul zone.

A combination of motor truck and rail, and motor truck and boat service is a morlem development in highway transportation in New England territory. The combination truck and rail service has been in existence on a small scale for a number of year's and is steadily growing in importance. This servios has developed largely in response to the demands of shippers for a rapid pick-up and delivery service of freight. The motor trucking eompany assembles the commodities and loads the freight cars, which are forwated daily, regardless of whother they are loaded to aipacity or not. The cars are shipped by rail to destination and the trucking company unloads and delivers the freight. This type of sorve insules rapid movement of L. C. I. freight, eliminates rehandling at junction points and terminals, and reluces the amount of terminal space necessary for incoming freight. Stone's Express is typical of the companies performing this type of service and operates in comnection with the New York, New Haven and Hartford Railroad in New England and the Pennsylvania Railpoad in the Middle Mtlantic States.

'The second type of joint service is a combination motor truck and lonat service, which has developed very rapidly in Tew Englamel during the past few year's. Tn most cases this service is limited to orernight delivery from New England points to New Tork City. This 
type of service is flexible and eapable of handling peak loads of traffic. The motor truck is used as a feeder from inland points to port towns and fumishes reliable and rapid service. The principal disadvantage of this type of shipment is the congestion of unloading wharves, particularly at New York City. The Starrin-New Haven line, operating between New Haven and New York City, is the best illustration of this type of service. This company maintains a sidewalk pick-up and delivery from Derbs, Shelton, Ansonia, Seymour, Beacon Falls, Nangatuck, Waterbury, New Britain, Meriden, Wallingford, Middletown and Hartford, Connecticut, to New Haven, Connecticut, and ships by boat from New Haven to all points.

This modern development in the correlation of highway transportation with rail and water agencies in the movement of freight is an economic function of motor transportation and offers an extensire field of derelopment supplementing rail and water service. It is not competitive and provides a pick-up and delivery service, allocates the short haul to motor-truck transportation and the long haul to rail and water and provides rapid transportation of freight.

Highway transportation of freight and pasengers is increasing in volume each year. Its development has been so rapid and the information as to its movement so meager that it is extremely difficult to lay down any definite principles as to the economic sphere of motor trucking companies engaged in the highway transportation of freight.

The following is a tentative ontline of the economic ficlds of motortruek transportation as a correlated part of our transportation system.

1. Organized urban motor-truck transportation in congested terminal areas consisting of motor-truck terminal to terminal freight transfers as well as pick-up to delivery service.-This can be illustrated by the operation of the U. S. Trueking Company in New York City in cooperation with the Erie Railroad in the transfer of freight from the Erie-New Jersey terminal to New York City for delivery. Carefully organized and efficiently operated motor trucking companies, assured of rail and steamship cooperation, will materially speed up terminal freight movement, decrease the volume of freight warehoused, reduce the cost of moving freight through terminals and expedite the rail delivery time of L.C.L. freight.

2. The organization of motor-truck freight service to supplement and extend existing rail and water transportation agencies.-The development of motor transportation companies in areas inadequately served with rail or water transportation offers an enormons possibility for the economic extension of highway transportation. This type 
of service is esperably desirable in the derelopment of new areats or localities with insutlieient transportation faccilities and will make available additional tomage for movement by rail or water. This is a non-eompetitive servere extending and supplementing existing rail and water agenceies.

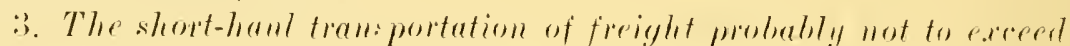
30 miles.-The freight transported by notor truck in the short-haul zone is largely a non-ommpetitive assembly and distribution of enmmodities. The differences in the density of perpulation in different areas, the distante between eities and areas of production and distribution, the prevaling type of protuetion and the type of rail or water transportation avalable may decratse or increase the above zone of the short hanul.

t. Motor-trucl: transpertation of a limited number of special comm-

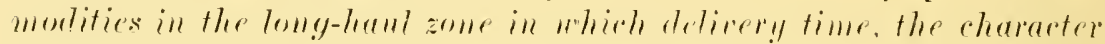
of the goods transported or the demands of the imdustry or trade in-

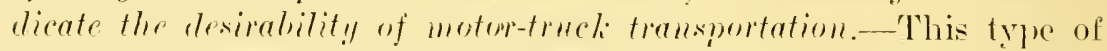
freight is hut a small pereentage of the total net tomage transported over the highways.

Dean Inghes: Does Prof. Mr Kay include the cost of arrying the commodity to the raiload and delivery from the railend to the destination? If not, has he any figmes to show what is the relative cost of delivering eommodities from origin to destination by the eombined system, compared to through motor trucks?

Dr. MeKay: I was eareful to say it was on the basis of difference between rates and not costs. Cost reords are in a rery moatisfactory rondition.

Dean Hughes: Ithen you said that a loi of small thuek transportation companies in New England hat falled, lave you foumd an! eridence that these "omplanies know what their services are cesting Hem?

Or. Mekay: The smaller truck transpontation companies. ats a

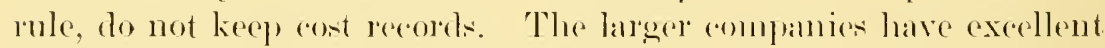
cost records. While I amonot answer your question on the basis of difference of cest of motor trucks and rail movement. I ean say that one of the largest companies has an organization of abont fis trucks operating out of lioston. 'They informed ws that their rates are about the salme as rail rates to eommon points. They keep accurate (ost records.

Dean Hughes: Is there anywhede in Hhe eombly any eridenee that motor-truek tramsertation is to be put moler the same regulation as that which railroals have? 
Dr. McKay: There are a number of states in which the regulation of intrastate motor transport companies' lines has been put under the Public Utilities Commissions of those states.

Chairman Johnson: Dr. Hatt reminds me that we should call attention to this report of Dr. MeKay as one of the evidences of the scope of broadness of highway research in general. This report opens up practically a new field in highway research. Such studies of transportation closely touch on the development of our highway systems.

\section{REPORT OF COMIITTTEE NUMBER 7, ON MAINTENANCE}

During 1923 the Maintenance Committee has made an investigation and study of seven different road-maintenance problems. In order to avoid duplication and to make responsibility more definite, each subject was ascigned to an individual member of the committee, who acted as a subcommittee to study and report on that particular subject. This report has been made up from the reports of those subcommittees. The subjects and assignments were as follows:

1. Gravel Corrugations-II. K. Bishop, U. S. Bureau of Public Roads.

2. Dust Prevention and Surface Treatment of Gravel Roads, Tnelnding Sizes of Mulch Gravel-G. C. Dillman, Michigan Highway Commission.

3. Crack-fillers for Concrete Pavements-Thomas E. Stanton, California Highway Commission.

4. Snow Removal and Snow-removal Equipment-IV. A. Tan Duser, Penneylvania Highway Commiscion.

5. Guide, Caution and Danger Signs-A. H. Hinkle, Indiana Highway Commission.

6. Maintenance Accounting-J. T. Donaghey, Wisconsin Highway Commission.

7. Maintenance Costs as Affected by the Life of the Road-W. A. MeLean, Deputy Minister, Toronto, Canada.

1. Gravel corrugations.-Dr. George E. Ladd, Economic Geologist for the U. S. Bureau of Public Roads, has made further study of this phenomenon. Questionnaires were sent by him to all the Highway Departments in the United States; thirty-two states replied and their answers were summarized. The consensus of these replies was that corrugations form in all gravel roads when the traffic becomes excessive-probably 500 or 600 vehicles per day. The formation of corrugations is in no way dependent upon construction or maintenance methods. Corrugations are most apt to oceur on flat grades. Two 
general reasons were assigned for the formation of corrugations: First, acutal kick-luack of material due to spin of drive wheels returning to the roal surface after a bounce caused by an mnevenness in the surface of the road. Seeond, displacement of material due to impact of the wheels, both front and rear, after the bounce. This displacement is aceentuated in rainy weather by the splashing of water (carrying binder and fine material out of the corrugations).

In other words. any slight nnevennes of the road which reacts on the springs of passing cars may cause a serice of corrugations. When the unevenness is hit by a passing atr, the springs are at first depressed; they then expand and virtually lift the weight of the car from the road. In some cases the whecls of the car actually leave the road surface; then the springs come back to normal and thr. weight of the car is impacted on the road surface. If the roml is wet, a slight indentation is marle; also, as the drive wheels are spinning. material is kicked back from the point of contact and a depression is thus started. After this depression has started it grows rapidly and other depressions are formed in a similar manner mntil we have a complete series. On flat grades during lains the depressions collect the water which is splashed out by passing relsicles, taking with it quantities of road hinder and fine material.

The states were almost mmanimously agreer as to the wethor of eure of corrugations-blading or dragging with heary equipment soon after rains, while the gravel is still moist, supplemented by occasional scarifyings. scems to have prodnced the liest results. It should be noted that this emre is not permanent, but lasts only until the next rain.

The committee does not believe that this subject shonld be continned as a major researeh problem. Te foel that caure and remerly of corrugations is pretty definitely agreed 11pom. Is it is exmorally eonceded that enrugatious form with lithe regard to construetion or maintenance methork, it would seem, then, that their prevention is a matter of traffic restriction or regulation. We do not lelieve that this is feasible.

2. Dust prevention and surface treatment of grated romds including sizes of mulch gravel. - Last year's maintenume report entained eonclusions from the prelininary report of the joint rexirch project of the University of Michigan and the Michigan State Highway Department. Their final report has now been puldished and distributed.

The Michigan Mighway Department has contimued this research work through the year, and they have surface-treated with refund tir approximately 45 miles of well-construeted gravel roads. These roads carry a tratlic of from $\$ 00$ to 1,500 vehiedes a day. 
The method which they have adopted this year is, briefly, as follows: The work is started early in the spring, when the frost is eoming out of the ground. The road is first shaped up and the gravel allowed to consolidate. Is soon as it is fairly well dried out, it is swept and an application of one-sixth of a gallon of refined tar per square yard is applied and allowed to penetrate into the surface. As soon as the surface takes on a brown appearance, approximately onethird of a gallon per square yard of the same cold material is applied and immediately given a top dressing of pea gravel or slag screenings. The Michigan Highway Department emphasizes the fact that the success of this kind of work depends largely upon the maintenance given the road, both before and after the treatment. Surface breaks are taken care of as fast as they oceur. They are filled with a cold mixture of refined tar and coarse sand. These patches are struck off and smoothed with a flat-lyottom shovel.

The Wisconsin Highway Commission has also treated a large mileage of gravel roads with refined tar, and they report satisfactory results. The Wisconsin method of treatment is similar to that used in Michigan. The road is first scarified and smoothed and allowed to compact. It is then swept and an application of eold tar applied from shoulder to shoulder, one-sixth of a gallon per square yard. The road is then opened to traftic for 24 hours and one-third of a gallon of cold tar per square yard applied and lightly sanded, using about 15 cubic yards of sand per mile for a 20 -inch width. The travel is then allowed to we the road, and in a few days a second sand coat is applied, using about 35 cubie vards per mile for a 20 -inch width.

For patching, a tar mastie is prepared and allowed to stand in piles along the side of the roar. Serenteen gallons of cold tar per entic yard of sand is nsed in preparing this mastic.

The Michigan Highway Department has experimented with calcium chloride and light oils for the purpose of dust prevention on their gravel roads. Their results with both have been satisfactory. They report the following points to be of great importance in calciumchloride treatment: The chloride should be applied while there is still some moisture in the gravel and the application should be in the neighborhood of from one-half to one pound per square yard, giving a light treatment which will help aroid future trouble. The application should be uniform over the surface. The road should be left free from all lumps or piles of chloride. Ordinarily, three applications during the season is sufficient, but the second or third application should be applied before the former application of material is entirely gone. In other words, there should be a little overlap rather than a dust interval. Care should be exereised in varying the amount to be applied to the different roads or sections of roads, inas- 
much as shaded portions as well as sand or clay gravel have much to do with the quantity of chloride that should be used.

Nearly every state is now maintaining most of its gravel road mileage with a mulch treatment of gravel. Various sizes and amounts are used. Little published data is arailable on this subject. The Michigan Department recomments the following: Replacement material should be limited to not exceeding one inch in size, preferably threequarters inch, with around 60 to 75 per cent of the material being retained on one-eighth-inch mesh. The clay content should be held down to not over five per cent and the filler should be substantial material, which will help get away from the dust nuisance. The muleh should be applier in very light courses, not exceeding one inch in deptl at any time, and should be applied preferably late in the season or during the spring months.

For future research work on this subject the committee would suggest a study of methorls of maintaining tar-treated surfaces with special reference to the edges. I study should also be made to overcome as far as possible breaks that oceur in the spring.

3. Crack-fillers for concrete parement.-Nearly every state and numerous municipalities are experimenting more or less with various tars and asphaltic fillers for the repair of cracks in concrete pavements. A few years ago there seemed to be a demand for a lightcolored filler which would harmonize with the color of concrete parement and thus be less noticeable than the black tars or asphalts. A satisfactory light-colored filler at a reasonable price has not been developed. The committee is inclined to believe that public sentiment on this question is changing. As the mileage of concrete roads inereases, the public becomes familiar with maintenance methods and does not look upon the black streaks with the horror that it did a few years ago. Furthermore, on heavily traveled parements the oil and grease droppings from cars soon stain the parement until the black crack-fillers are not conspicuous.

One of the most extensive tests of crack-fitlers is being carried on by the Iowa Highway Commission on a concrete road immediately outside of the city of Des Moines. On this experiment three tars, nine asphalts and blown oils, one emulsified asphalt and one light-colored material were used. The experiment has just been started. One barrel of each material has been applied and is now heing tried out in service. The Iowa IHighway Commission will issne periodic reports on this test; the first one will be available next spring, after the road has gone throngh the winter.

The committee does not helieve that further seareh for a lightcolored filler is necessary. We do believe, however, that further research to determine the best specification for asphalt and tar fillers is desirable. 
4. Snow removal and snow removal equipment.-The Bureau of Public Roads is now making a study of this subject in a number of states which are engaging in snow removal. When this investigation is completed a report will be prepared and probably made available for distribution. The committee believes that further research is necessary on this subject, particularly with the end in view of developing snow-removal equipment especially adapted to highway work.

5. Guide, caution and danger signs.--The rapid increase in recent years of intercounty, interstate, and even international traffic has brought a demand for standardization of guide, caution and danger signs. The idea of standardization of signs is that one can familiarize himself with the signs in his own locality, and ean then proceed to travel in other parts of the state or in other parts of the United States with assurance that he need not learn a new set of signs in every county or state through which he may pass.

The most comprehensive study of this subject during 1923 was undertaken by a committee of the Mississippi Valley Association at their annual meeting in Chicago in January, 1923. Some of the outstanding features of the report are:

Highway signs are classified into three groups: (1) Ronte markers, including road numbers and the distiuguishing symbols accompanying same; (2) Warning signs; (3) Guide and information signs.

A. Route markers. Every state should adopt a distinctive symbol for its route markers.

B. Warning signs. Should be uniform in all states and should not be used except where necessity is obvious.

(1) Color. Warning and guide signs should be painted in black and white.

(2) Iocation. Waming signs should be placed with the center 3 to 4 feet above the center of road elevation and 1 foot outside of the shoulder line. They should be placed from 300 to 500 feet in advance of the point of danger.

(3) Shape and size. Warning signs should be 2 feet in diameter ant the shape shonld indicate the nature of warning, as follows:

Round . . . . . . . . . . Railroad erossings

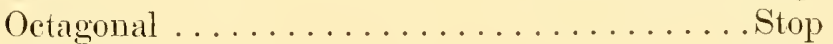

Diamond .......................... Slow

Square ..................................

Rectangular...... For guide and information signs 
C. Guide and information signs should be rectangular. All adrertising signs should be forludden on the highway right of way.

The committee feels that the work of the Misiswipli Valley Issociation is a step in the right direction. The next step is to make nation-wide rules, so that uniform signs may be had in all parts of the United States. We would recommend that some national organization, such as the American Asoctation of state IIghway Otlicials, make further study of this problem and standardize as far as posible all highway guide, caution and danger signs.

(i. Maintenance accounting.- Last year yomr committee recommonded that research work be undertaken to develop the nost feasible miform system of maintenance accomts, so that mantenance reports of various states might be put on a comprarable basis. We are glad to report this yoar that both the Mississippi Valley and the Amerian Associations of State Highway Officials have committees at work on this problem. The following report was alopted by the Missiscippi Valley Asoriation, and these states are attempting to make their acoomenting conform to the general classifieation.

"Expenditures by the states. throngh their mantenance organizations. shall be classified in their anmual yeporte as follows:

1. Maintenance Alninistration.

2. Maintenance P'roper.

:). Additions and Betterments.

4. Parks, Camping-grounds and Roadside Beautification.

"The last three clas-ificutions shall be cherengl to a specific section of road.

"Aclditions and betterments shall inchute expenditures for the increased permanent value of the road to aceommonlate traflie. This will include the cost of-

1. Inereased width of surface or roatbed.

2. Inereased depth of wearing surface over any previous maximinm depth.

;. New gllatid rails.

4. Now wall..

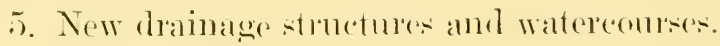

6. New subdrains.

7. Impmoving grades. aligumont and vision."

Wisconsin has aldopted the following chassification:

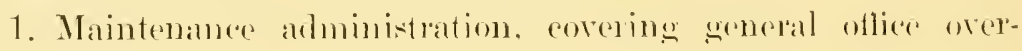
head. 
2. Maintemance supervision, covering district oflice overhead.

3. General maintenance, covering patrol and repair work. This cost is kept by patrol sections.

4. Reconstruction; covers replacement to restore to original condition. Cost kept by patrol sections.

5. Adritions and bettermente; covers expenditures which change the section of the road and produce increased capital investment.

6. Marking and signing; covers maintenance of all traffic guides on state system.

It will be noted that these classifieations an be consolichted to conform to the four main divisions of the Mississippi Talley report.

When maintenance rosts are kept in a miform manner by the various states. it will be possible to make comparisons of such costs. This, howerer, is only the first step townd uniform maintenance reports. Maintenance reports, even thongh summarized from uniform records. are not of the greatest value as long as they are based on a per-mile cost. The next step is to reduce such costs to a tonmile unit: then useful comprisons browern states and between types can be undertaken. This, of course, involves traflic census data and

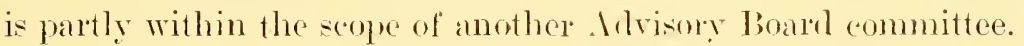

We would recommend rontinued efforts, in vicw of producing a standard basis of maintenance accounts for all state highway departments. We would then reammend that, for complative purposes. maintenance costs on a representative mumber of roads in each state be reduced to cost per ton-mile of tratfic on such roakls.

7. Maintenumere costs as affered by the life of the road.-Little matter is avaiblibe on this subject. Com-tantly increasing traftic makes it almost imposible to determine acemately the effect of age on maintenance costs. Wre belicre. howerer. that the subject is worthy of further consideration.

The Maintenance Committee has been handioapped in its work because funds have not been arailathe for committee meetings. All of the work has been handled by comespondence, the committee never having held a meeting since its appointment. We believe that two committee meetings a year are necessary for satisfactory work. One committee meeting should be held soon after the annual meeting of the Adrisory Board. for the purpose of outlining the year's work. The second committee meeting should be held just prior to the annual meeting of the Advisory Board, for the purpose of presenting and discussing subcommittee leports and formulating the annual report of the committee. 
Mr. Root: I would like to say, in conclusion, that I concur in what Mr. MacDonald said last night. The biggest problem of a research organization is to lay out its program. I believe that if the maintenance committee can once lay out a definite program for the next year it will have gone a long way. Once the program is laid ont, we shall have no trouble in securing cooperation of state highway departments. The American Association of State IIighway Officials has a maintenance committee which has a subcommittee on cooperation in research. The purpose of this body is to conperate with that committee on research problems.

Mr. II. (4. Shirley, State IIighway Engineer of Virginia: My ol,servations have been that these corrugations in gravel and soil roads occur in dry weather more than in wet. In Mr. Root's report he referred to kicking back of water and mud which built up these corrugations. My experience has been that these corrugations occurred during unusually dry weather, when we wore suftering from dust.

Mr. Upham: I think this report lorought ont some excellent ideas. I do not agree, howerer. that corrugations should not be continued as a research subjeet. 1 : Mr. Shirley says, we have more corrugations in dry weather than in wet weather. One of the recommendations of the committee is as to scarifying the roat. From a practical standpoint, a sand-clay or top-soil road will stand just so much scarifying and no more. From another point of view, scarifieation not followed by proper weather gires a result almost as had after scarification as before. Just one other point in connection with these corrugations. The committee has recommended scarifying. If weather conditions are favorable, scarifying is satisfactory for the time being. In some cases we have lightly scarified the surface and added an unusually strong binding clay, and then rescarified and redisked it, and we have found by addition of the binding clay that we lave increased the surface tension of that road and the corrugations do not develop so quickly after that. One cannot always get strong binding clays. During the dry spells the corrugations are quite often corrected by dry dragging.

Mr. Blair: Much complaint over the eomtry is directed against the coarse material used in repairing cormgations. In leveling up the road, either hy dragging or otherwise. what methed have you used to reduce to a minimum the effect of coarse material in corrugations causing discomfort to travel and injury to tire?

Mr. Upham: If we could get a homogeneons surface we should not have troulde with corrugations, hut in soil rouls it is imposible to get homogeneons materials. The material varies with almost every 
foot of road. We have to treat almost every section of the road differently.

We carried on a census in North Carolina in connection with the Bureau of Public Roads to determine, if possible, the limitations of the sand-clay and top-soil roads. We found that the figures were somewhere around 400 vehicles per day. This count included mostly passenger cars, a very small percentage of heavy trucks, a few light trucks and some horse-drawn vehicles. The particular road on which this investigation was made was an arerage sand-clay and top-soil road which satisfactorily withstood 400 vehicles. On another road, made of practically the same material, it was found that when the number of rehicles reached 500 or 600 the maintenance became somewhat high and the road corrugated badly. It seems that the limitation of sand-clay and top-soil road is somewhere around 400 rehicles per day. Of course, there are wille variations of that type of road, depending on the quality of the material in the road surface.

Mr. Manly: I annot see why the roal thould arry 400 ears per day satisfactorily and then go to pieces on 500 or 600 per day, unless there is some heating or fatigue effect.

Mr. Uphan: After the corrugations once start they derelop rapidly. This may possibly be a factor if not the reason. When there is a small number of vehicles, the maintenance forces get ont in time to catch corrugations in between the vehicles. When there is a large number of vehicles, there is not as initensive maintenance per rehicle. On tourist routes that pass throngh the state, we get as high as 800 to 1,000 vehicles per day. The particular road which is used mostly by these tourist passenger cars is corrugated rery badly, and the east and west roads, made of practieally the same material, that do not carry a traffic of more than half of these other roads, will be in very good shape and not corrugated and the maintenance remain quite low. These same north and south tourist lanes remain in good condition during almost the entire year, exeept when the tourist traffic is going north or south, and then these roads start corrugating. I do not know whether I can give you the reason why a larger number of vehicles would be harder, in proportion. on the road than the lower number of vehicles. unless it is dne to the fact that they do not receive as much maintenance in relation to the number of vehieles.

Prof. Eno: Are the tourist cars heavier and driven at a more rapid rate of speed than the local cars, as a rule?

Mr. Upham: I believe not. In general, many of the touring ears are Fords. Local cars have little respect for speed laws. 
Prof. Lay: We were getting ready to make some inrestigations on the action of the rehicle when traveling orer some bumps and wanted to get a general idea of this; so we nlade a simple experiment with a Ford ear, a rail and a pile of sand. We set the rail on a concrete road and sprinkled some sand on the road on the other side of it. We drove the Ford over this rail at rarous speeds. It had tires with a non-skid tread, so that we could observe any skidding or slipping of the wheets on the sand. It low speed, when the front wheels first struck the parement they rolled along without any slipping, as we could observe the clear imprint of the non-skid tires. At higher speeds they bounded up and struek again several times. The rear wheels always wiped the sand off the spots which they struck the first time, and as we increased the speed the rear whects jumper a little farther and perhaps would bound and strike again. When driving the ear at much higher speeds the whole borly was raised so high that while the springs did force the whects and axle down, the wheck did not touch the road until at the end of the second "hop" of the rear wheels, when they struck with great force, clearing away the sand as before. This simple test throws considerable light on the corrugations formed on a dry gravel road. It shows that there can be a relation between the period of the springing system, the speed of the ear and the distance between corrugations. It shows clearly how the driving wheels gain in speed while off the ground and abrade the road surface when they do eome down on it.

Mr. Crandell: I should like to suggest that some one on the committee formulate a definition of gravel, becanes throughout the country no one seems to know just what gravel is. I have tried experiments of getting students to duplicate on a blackboard in actual size their idea of gravel. I had seventeen students at the board and got seventeen different kinds of gravel. One man thinks sand is gravel and another man thinks crusher rock or large pobbles is gravel. Te should have a dear definition of what constitutes gravel.

Chaimon Johnson: This was always an interesting subject for discuswon. No one seems to get mueh further than the definition of the Nassachusetts Ilighway Commission, that gravel is stone broken by nature.

Mr. Manly: On the matter of corrugations of gravel roads, Mr. Tpham hrought out the point that maintenance cost has been on a per-mile basis buther than per vehiele passing. Corrugations, therefore, have possibly formed on the basis of number of vehicles passing in any given time, lout within the rejair periods; so that if that is the whole answer, that is all right. On the other hand, if there is anything else in it, like the question of fatigue or the time element in 
settling of the subsoil or the top-dressing, it seems that it would be rather important to determine it. It could be determined if two pieces of road as nearly alike as possible were maintained in direct comparison, the one on the present system and the other on the basis of the number of rehicles passing rather than on the mileage basis. It could be settled if this type of road is limited to so many rehicles per day, or if it were simply limited to so many rehicles per unit of maintenance expense.

Chairman Johnson: I understand the number of vehicles in each instance amounts to 400 or 500 per day.

Mr. Manly: But if it is 400 rehicles per day, and you maintain that road once a month or once in six months, it makes a difference. The question I bronght up was: Ire those corrugations due to passing a critical point in the expense of maintenance of that road per rehicle passing, or is there some element of the frequency of passing that is a criterion beyond which you cannot go without enormously addling to the expense?

Mr. Hubbard: It seems to me that it is not unreasonable to suppose that there is a limit to the number of rehicles that can pass orer a gravel road. The suggestion has oceurred to me that the resistance to displacement of surface of gravel road or top-soil road is more or less dependent upon the amount of moisture which the surface holds. During the day the moisture which is absorbed during the night gradually disappears if the weather is dry. The resistance has therefore become less as the day progresses. It is not unreasonable to suppose that if the number of rehicles is greater the punishment will be more severe and the formation of corrugations more rapid.

Mr. Bishop: I think that Mr. Upham and Mr. Shirley both disagree with conditions reported, and while I want to confess I am not an expert on this subject. I have studied with Dr. Ladd on gravel roars and I think that perhaps a part of the difference of opinion may be explained by the fact that Dr. Ladd's report covered the New England States and some of the Northwest States on gravel alone and did not extend to sand clay.

The statement made, that the corrugations occur when the number of vehicles reaches about 500 or 600 , is merely a summation of statements made by state highway departments that they actually did occur between those limits. The question of maintenance, or the scarifying or dragging, is the summation of consensus of opinion of most of the state highway departments which reported on corrugations of gravel roads. His investigation did not cover the sand clay.

Mr. Older: I understand the committee recommends that main- 
tenanee costs be reported on the basis of ton mileage. I doubt very seriously the value of sueh a basis for reporting maintenance costs. For example: It might readily be conceived that a 4 -ineh or $\bar{j}$-inch conerete road might sustain 100,000 ton-miles or more of passenger ear traffic without damage of any kind, and yet be practically destroyed by 1,000 or 2.000 ton-miles of freight traffic earried in units imposing wheel loads of four or five tons. To report maintenanee costs on the basis of ton mileage would add enormously to the cost of keeping the records without necessarily adding to their value.

Prof. Agg: One of the things Mr. Root had in mind is suggested by the problems that are before Committee No. 1 in the determination of transportation costs. Certainly we ought to get some figure to represent transportation eosts on highways, and there must be some way to correlate those costs with the rolume of traffie on the highway, because we know maintenance costs inerease with traftic. I would suggest that, whaterer unit might be adopted, it is highly desirable that there be adopted some systematic way of reporting maintenance eosts which will correlate those eosts with the amount, and probably the type, of traffic that oecasions those maintenance eosts. Possibly a flat ton-mile is not the correct basis, but there should be some equivalent way of reporting costs. In attenpting to get at the costs that have been reported, the committee has found a great deal of diffieulty in interpreting the costs in sucls a way that those that are reported from some of the states-such, for instance, as New York State-can be compared with reports that come from Illinois, beeausc of differences in practices in that respect. We do not use the same unit in reporting the traffie of the highway, neitler do we use the same unit in reporting maintenance costs. I think that these committees should agree upon a system of units. Mr. Hamlin's committee and Mr. Root's eommittee might submit a unit for reporting traffic - they might work out an agrecment as to a method of reporting traffic, a system of units that all would useand likewise if the maintenance costs could be reported with some statement as to volume of traffic it would help.

Mr. Shirley: I believe that some such distribution has got to be made of highway traffic. We know that with the passenger velicele it is the number rather than the weight, and with the freight rehicle it is the weight rather than the number. 


\section{STATEMENTS FROM REPRESENTATIVES OF CONSTIT- UENT ORGANIZATIONS}

Mr. Prevost IIublard, representing the American Society for Testing Materials: During the past year the American Society for Testing Materials has revised, or adopted as new, a total of forty methods of tests and specifications for highway materials, and has submitted six or more standard specifications and tests to the American Engineering Standards Committee for adoption as Tentative American Engineering Standards. Upon recommendation of Committee D-4, the Society has adopted four standard specifications for slag and stone block. It has revised three standard tests for bituminous materials and one standard specification for materials for cement mortar bed for brick and block parements. It has revised two tentative methods for testing subgrade soils and bituminous materials, and eleven tentative specifications, one for non-bituminous, and ten for bituminous materials. In addition, it has adopted as tentative one new test for bituminous material, two new specifications for bituminous materials, and five new specifications for non-bituminons material. It is expected that at the next annual meeting of the Society a considerable number of new specifications and methods of test for highway materials will be presented, and that many existing tentative standards will be recommended for advancement to standard. It is beliered that quite a number of the new tests will be of value to research workers on highway problems as a means of securing data which is necessary to the solution of such problems, even though the problems themselves are not principally concerned with materials of construction.

Mr. Ward P. Christie, Research Engineer of the Associated General Contractors of America: In undertaking the investigation of certain subjects concemed with highway derelopment, the Associated General Contractors have proceeded on the following assumptions:

1. That problems of design and engineering will be successfully solved by the country's technical and professional minds.

2. That the development of local and state highway systems to meet the needs of agriculture, industry and pleasure will be dereloped by highway engineers in cooperation with representatives of these various interests and in spite of adverse political influence.

3. That it is the duty of construction companies to study the means of building these systems properly and economically.

With these assumptions in mind, therefore, the association has concentrated its investigations upon elements that affect the cost of 
construetion. Though these subjects may, at casual glanee, appear remote from the problems of design and engineering, yet ther are. in the last analysis, the controlling factors in deternining whether the engineer shall be able to execute his conceptions and render his utmost service, and whether the public, which he is attempting to serve, will appreciate his efforts and receive a satisfactory mileage for its appropriation.

The field of research and investigation that may properly be assigned to construetion eompanies is practically virgin in so far as recorded data and authentic information is concerned. Text-hooks and treatises have been written in great numbers, but they deal primarily with those factors that are more or less definite in eharacter and fail to touch the les: tangible problems involved in the inexact science of construction ceonomics. It is to problems of this nature, concerned more directly with the business end of construetion, but also to a great extent with the business of the designer, that the Associated General Contractors are devoting their efforts.

The principal subjects under investigution may be outlined as follows:

(1) Material supplies; (2) The field working force; (3) Construction methods; (4) Fquipment development; (5) Seasonal suspension of work: (6) Preventable hazards in the industry; (7) Comparative statistical tabulations.

The following is an ontline of the work which the Associater Cieneral Contractors are carrying on in their individual field:

1. Material supplies.-Data is being compiled from government and industrial sources to show the quantities of the prineipal construction materials necessary to serve the industry, so that engiueers and construction companies in laying their programs may have information on production that will assist them in fitting their demand to the production eapacity.

2. Field worling force.-Efforts are being male to induee young men to join the ranks of construetion lahor and to train them in the use of specialized machines that are rapidly increasing in higlwway construction. Incident to this work is the tabulation of estimated shortages and the study of wages and cost of living.

3. Methods.-A study of methods is being carried on by individual companies, as the Associated General Contractors as an organization has not yet obtained the funds suffieient to cary on this work. Reports of progress and new methods are furnished, lowerer, hy individual companics to the association and to the trate magazines.

4. Equipment development.-In cooperation with manufacturers 
of construction equipment, the improvement and development of machines is being handled through the Joint Committee on Construction Equipment, which has, to date, practieally completed work in two lines, namely, wheelbarrows and eoncrete mixers. These items of plant have been standardized within the past year and a time limit of Jannary 1. 1925, has been set for the elimination of non-standard types. The wheelbarrow standards have already been put into effect.

5. Seasonal suspension of work. - The saring of construction costs that may be produced by continuous operation in the construetion industry has never been estimated, but the tendency of this continuity is well known. The Associated General Contractors for the past two years has devoted consideralble effort and money in seeking to interest other elements of the industry in this question. Its policy has been that, rather than wait for quantitative estimates and exact data, it could more profitably urge adoption of the policy knowing that the energy extended would result in great economy. With this question is closely linked the problem of winter eonstruction methods, in which the cooperation of the engineering profession in experimental work is urgently needed. How far the seasonal depression can be eliminated in the highway field is uncertain, but the consensus of opinion is that, where it can be brought about, the efforts will effect considerable saving.

6. Removable hazards of the industry.-As one of the important elements of cost in the construction project is the assumption of certain hazards incident to the business world and to natural eauses, an cffort is being made to induce the owners of public construction to assume those hazards which such owners can most economically assume rather than ineorporate them into the cost of construction. Many of these hazards, occurring but once in the lifetime of a construction company, are sufficient to throw it into bankruptey, and it must obviously protect itself by insurance or contingency charges. The infrequency of such event makes it considerably more economical for the owner to accept such hazards. Work on this subject is being continued in eontingent eooperation of the American Association of State Highway Officials and rarions arehitectural and engineering organizations. The report upon the subject was issued last December by the joint committees of the first-named organization and the Associated General Contractors.

7. Comparative statistical relations.-In order that construction companies and others interested may keep track of the trend of various factors influencing the industry, graphical analyses comparing these factors are being carried in the magazine of the Associated 
General Contractors. Among the statistical compilations carried from month to month are the construction cost index, the construction rolume index, based on the quantity of material shipped, index numbers of wages, cost of living and material prices, contracts awarded, volume of transportation and other data of a similar nature.

Statistics pertaining to the construction industry have been meager in past years, but new tabulations are being started, and within the course of a few years sufficient data will be available to intelligently interpret the trend of economic factors within the industry.

The Associated General Contractors, in common with other national organizations, is restricted in its research work by lack of personnel, but the anticipation is that work of this nature will be expanded materially within the next two or three years.

One of the most important subjects upon which the construction companies of the comntry would like to see a definite determination made by the engineering profession is the question of hardness of aggregates and their suitability as road materials. At present, aggregates of different French coefficient are specified in particular states, apparently for highways of the same general type. Conclusive information upon this subject will doubtless make possible the utilization of many local sources of materials and result in a decrease of unit costs.

Mr. A. D. Flinn, representing the Engineering Foundation, gave assurance of the friendly support of the Enginecring Foundation.

Prof. C. J. Tilden, speaking for $M r$. William $P$. Eno, of the Eno Foundation, expressed the continued interest and cooperation of the Eno Foundation in the work of the Advisory Board on Highway Research.

Mr. Pyke Johnson, of the National Automolite Chamber of Commerce: The most interesting bit of research undertaken by the National Automobile Chamber of Commerce in recent months is an analysis of the financial aspects of the highway program in its relation to the total tax bill of the nation, by John E. Walker, former tax adviser to the United States Treasury.

Mr. Walker first determined the total national, state and county taxes, then found what percentage of these were devoted to highway work, where the funds so cxpended were obtained, and to what uses they were put.

As just one outstanding fact of interest, his study shows that while $\$ 1,000,000,000$ in round figures were expended for highways in 1921 , and while the total taxes collected in that year were $\$ 9,000$,000,000 , the actual cffect on the gencral taxpayer was a contribution 
of less than six cents of each tax dollar for highway purposes due to the many special taxes levied for highway work.

The study has only recently been completed, but will be ready for distribution within the next month.

Another survey of general interest, now nearing completion, is that of the Chamber of Commerce of the United States, which has had committees working for nearly a year on the broad question of transportation. One of these, headed by Alfred H. Swayne, VicePresident of General Motors, and including in its membership agricultural, electric and steam railway, waterway, motor and public representatives, has been engaged in studying the relation of highways and highway transport to other transportation agencies. Another committee, including A. J. Brosseau, of Mack Trucks, Inc., and Roy D. Chapin, President of the Hudson Motor Car Company, has been going into the problem of transportation taxation.

Waterways, railroad consolidations, governmental relations and the freight rate structure are other problems under review. These reports will be issued this month.

Mr. II. W. Alden, representing the Society of Automotive Engineers: The Society is continuing its work on a number of different projects. Some of these are investigations by the Bureau of Standards. Tests are to be undertaken in coopcration with the Bureau of Public Roads and the Rubber Association. This work covers impact tests, automobile brake tests and headlight specifications.

Dean Anson Marston, representing the Association of Land Grant Colleges: The members of the Association of Land Grant Colleges are the land-grant colleges of the United States, including Alaska, Hawaii, and Porto Rico. These colleges were organized in accordance with the Morrill Land Grant Act of 1862, amended by later legislation. Each of these institutions has some endowment provided by the United States Government, and in addition to the income from these endowments, the institutions also receive considerable annual sums from the central goverument, provided by Congress through continuing appropriations. The United States Goremment retains some general authority over all of these land-grant colleges, and in a general way it may be stated that they constitute the only educational institutions in the United States having any such official national relation.

In addition to the funds received from the national government, each of these institutions has state support, and in most of the institutions the state funds are several times those provided by the national government; hence each land-grant college has actual official relation to the nation and to its state. They are unique in this respect. 
The United States Government appropriates very large sums of money anmually to the land-grant colleges for the support of agricultural research, but as yet makes no corresponding appropriation for the support of engineering research. Howerer, the land-grant colleges, by legislative aetion on the part of some states and without such action in others, have proeeeded to organize engineering experiment stations in twenty-four different states. In addition, engineering research is carried on actively in many of the land-grand colleges which do not have formally organized experiment stations.

The Association of Land Cirant Colleges is promoting the organization of such stations and maintains a Standing Committee on Engineering Experiment Stations. Through this committee the Association publishes quarterly the "Engineering Experiment Station Record (in mimeographed form), which is sent to all of the landgrant colleges. Through the "Engineering Experiment Station Reeord" the engineering experiment stations and other engineering research organizations of the land-grant colleges in the several states are kept informed definitely of all engineering researches in progress in such institutions throughout the United States. The several institutions thus can cooperate in research and can avoid undesirable duplication. The cooperation secured to date has been of most satisfactory eharacter.

In general, each college organizes its researches on the project basis, with definite assignment of research staff and of funds to each project. Some of these projeets continne for several years, in which case progress reports are required from time to time. Eventually each project normally results in the publication of one or more bulletins.

From the fortheoming annual report of the Engineering Experiment Station Committee (which for such report collects definite statisties from every state at about this time each year), it appears that the land-grant colleges of the continental United States expended about $\$ 589,580 \mathrm{in}$ engineering researeh in the year 1928 ; that in that year their engineering research staffs inchuded about 95 members full time, about 88 member's part time paid, and more than 241 members part time with no extra pay; also, it appears that up to December 31, 1923, the colleges will have published in excess of 469 engineering research bulletins. of which approxinately 58 are for the year 1923 .

The magnitude of the engineering resurch work arried on by the land-grant colleges may be understood better by comparing it with that promoted by the Engineering Foundation. The land-grant eolleges spend more ammally for engineering reseatreh than the entire 
endowment of Engineering Foundation. Undoubtedly the landgrant colleges together constitute the largest organized engineering research ageney in the country.

The land-grant eolleges are espeeially interested in highway research, and are espeeially qualified to eonduet such researeh, and they are especially desirous of joining in a nation-wide program of highway researeh.

a. They are the only nationally endowed edueational and researeh institutions in the several states.

b. Each of them is also a state institution, and for that reason is especially well qualified to cooperate with the state highway commission.

For these reasons the L-sociation of Land Grant Colleges made application in 1922 for admission to the Advisory Board on Highway Rescarch, which applieation was granted immediately.

The youngest member of the Advisory Board on Highway Research submits this report with its very best good wishes for the Board.

Prof. I. H. Blanchard, representing the Yational IIighway Traffe Association, sent in the following written report:

In the 1922 Report to the Advisory Board on Highway Researeh, the titles of about thirty-five national eommittees devoted to research problems were included. Although all of these committees are actively engaged in research work, in order to avoid repetition, in this report only the following titles of those conmittees which will report at meetings during the current year of 192:3-1924 will be mentioned.

"Licene Fees and Motor Tehicle Taxation."

"Regulations Covering Speerls, Weights and Dimensions of Trailers."

"Equitable I)istribution of Cost of Construction. Interest on Bonds, Replacenents and Maintenance of State Ilighways."

"Development of Transportation."

"Interrelationship and Coorlination of Railway, Waterway, Airway and Highway Transportation."

"Traffic Capacity and Widths of Highways Outside of Munieipalities."

"Widths of Roadways and Sidewalks in Munieipalities."

"Highway Transport Franehises."

"Highway Transport Clearing Houses."

"Uniform Highway Signs."

"Traffic Center Lines on Roadways."

"Safety Regulations at Railroad Grade Crossings." 
"Mechanical Devices for ITighway Truffic Regulation."

"Relative Ethiciency of Diflerent Types of Car-stop Safety Zomes and "Their Relation to Parking and Ranking Regulations."

"Segregated and One-way Streets in Mimicipalities."

The national committees listed in this report, as well as our other committees, are composed of from three to fifteen specialists.

Our reports are nimeographed or multigraphed and are available for distribution to those who are particularly interested, and hence are available for review and reference by any comnittee of the Advisory Board on Highway Research.

\section{FLECTION OF OFFICERS}

Report of Committec on Nominations:

The following nominations for officers of the Alvisory Board were reported by the Committee Chairman, Mr. A. 'T. Goldbeck:

Chairman, Dean A. N. Johnson (renominated).

Vice-Clatiman, Mr. A. D. Flinn (renominated).

Executive Committee:

Mr. Thos. II. MacDonald (renominated).

Prof. T. R. Igg (renominated).

Dr. II. C. Dickinson.

Mr. C. M. Upham.

Mr. 1. J. Brosseau.

The report of the committee was accepted and the Director cast the ballot of the Board for the nominees.

Chairman Johnson: $\Lambda$ meeting of the Excentive Committce is called immediately following adjoumment.

Adjourned at $10 \mathrm{p}$. $\mathrm{m}$. 


\section{Publications of the National Research Council Bulletin Series}

\section{Volume 1}

Number 1. The national importance of scientific and industrial research. By George Ellery Hale and others. October, I919. Pages 43. Price \$0.50.

Number 2. Research laboratories in industrial establishments of the United States of America. Compiled by Alfred D. Flinn. March, I920. Pages 85. Price \$I.00. [Out of print. See Number I6.]

Number 3. Periodical bibliographies and abstracts for the scientific and technological journals of the world. Compiled by Ruth Cobb. June, I920. Pages 24. Price $\$ 0.40$.

Number 4. North American forest research. Compiled by the Committee on American Forest Research, Society of American Foresters. August, 1920. Pages 146. Price $\$ 2.00$.

Number 5. The quantum theory. By Edwin Plimpton Adams. October, 1920. Pages 8I. Price \$I.00. [Out of print. See Number 39.]

Number 6. Data relating to X-ray spectra. By William Dirane. November, I920. Parges 26. Price $\$ 0.50$.

Number \%. Intensity of emission of $\mathrm{X}$-rays and their reflection from crystals. 13y Bergen Davis. Problems of X-ray emission. By David L. Webster. Decemler. 1920. Pages 47. Price $\$ 0.60$.

Number 8. Intellectual and educational status of the medical profession as represented in the United States Army. By Margaret V. Cobb and Robert M. Yerlies. liebruary, 1921. Pages 76 . Price $\$ 1.00$.

\section{Volume :}

Number 9. Funds available in 1920 in the United States of America for the encouragement of scientific research. Compiled by Callie Hull. March, 1921. Pages 8I. Price \$I.00.

Number 10. Report on photo-electricity including ionizing and radiating potentials and related effects. By Arthur Llewelyn Hughes. April, I92I. Pages 87. Price \$1.00.

Number 11. The scale of the universe. Part I by Harlow Shapley. Part II by Heber D. Curtis. May, I921. Pages 47. Price $\$ 0.60$.

Number 12. Cooperative experiments upon the protein requirements for the growtl of cattle. First report of the Subcommittee on Protein Metabolisn in Animal lieeding. By Henry Prentiss Armsby, Chairman. June, I921. Pages 70. Price $\$ 1$.oo.

Number 13. The research activities of departments of the State government of California in relation to the movement for reorganization. By James $R$. Dounglas. June, I92I. Pages 46. Price \$0.60.

Number 14. A general survey of the present status of the atomic structure problem. Report of the Committee on Atomic Structure of the National Research Conncil. By David L. Webster and Leigh Page. July, I92I. Pages 6I. Price \$0.75.

Number 15. A list of seismologic stations of the world. Compiled by Harry O. Wood. July, I92I. Pages I42. Price \$2.00.

\section{Volume 3}

Number 16. Research laboratories in industrial establishments of the United States, including consulting research laboratories. Originally compiled by Alfred D. Flinn; revised and enlarged by Ruth Cobb. December, 192I. Pages I35. Price $\$ 2.00$. 
Number 1\%. Scientific papers presented before the American Geophysical Union at its second annual meeting. March. 1922. Pages 108. Price \$i.50.

Number 18. Theories of magnetism. By members of the Committee on Theories of Magnetism of the National Research Council. A. P. Wills, S. J. Barnett, I. R. Ingersoll, J. Kunz, S. L. Quimby, E. M. Terry, S. R. Williams. August, 1922. Pages 261. Price $\$ 3.00$.

\section{Volume 4}

Number 19. Celestial mechanics. Report of the Committee on Celestial Mechanics of the National Research Council. E. W. Brown, G. D. Birkoff, A. O. Leuschuer, H. N. Russell. September, 1922. Pages 22. Price \$0.40.

Number ?0. Secondary radiations produced by $\mathrm{X}$-rays, and some of their applications to plyssical problems. Arthur H. Compton. October, 1922. Pagres 56. Price $\$ 1.00$.

Number 21. Highway research in the United States. Results of census hy Arl visory Board on Highway Research, Division of Engineering, National Research Comcil, in cooperation with the Bureau of Public Roads, United States Department of Agriculture. William Kendrick Hatt. October, 1922. Pages 1 (12. Price $\$ 1.50$.

Number 2:. Mechanical aids for the classification of American investigators, with illustrations in the field of psychology. Harold C. Bingham. November, 1922. Pages 50. Price $\$ 0.75$.

Number 23. Certain problems in acoustics. Compiled by the Committee on Acous tics, National Research Council. November, 1922. Pages 31. Price \$0.50.

Number 24. Electrodynamics of moving merlia. Report of the National Rescarch Conncil Committee on Electrodynamics of Moving Media. IV. I:. (3. Swann, Joln T. Tate, H. Bateman, and E. H. Kennard. December, 1922. Pages 172. Price $\$ 1.50$.

Number 25. Celestial mechanics. A survey of the status of the determination of the general perturbations of the minor planets. Appendix to the report of the Committee on Celestial Mechanics, National Research Conncil. A. O. Lenschner. December, 1922. Pages 73. Price \$1.00.

\section{Volume 5}

Number 26. Cooperation with the Federal Government in scientific work. Ji. IV. Allen. December, 1922. Pages 27. Price $\$ 0.50$.

Number $2 \%$. The present status of visual science. Leonard Thompson Troland. December, 1922. Pages 120. Price \$1.50.

Number 28. Algebraic numbers. Report of the Committee on Algebraic Numbers, National Research Council. L. E. Dickson, H. H. Mitehell, H. S. Vandiver, G. E. Wahlin. February, 1923. Pages 96. Price \$1.50.

Number :9. The status of scientific research in Illinois by state agencies otler than the University of lllinois. Leonard D. White. March, 1923. Pages 8.3. Price $\$ 1.00$.

Number 30. Selected topics in the field of luminescence. Iirnest Merritt, Lilward L. Nichols, C. D. Cliild. Marcin, 1923. Pages 126. Price \$2.00.

Number 31. The organization and activities of the Committee on Scientific Research of the State Comeil of Defense of California. T. H. Coodspeed. April, 1923. Pages 43. Price $\$ 0.75$.

\section{Volume 6}

Number 3:. Proceedings of the Second Annual Meeting of the Advisory Board on Highway Research. Division of Engineering, National Research Conncil. William Kendrick Hatt. May, 1923. Pages 89. Price \$1.25.

Number 33. On the formulation of methods of experimentation in animal production. E. B. Forbes and H. S. Grindley. June, 192.3. Pages 54. Price \$1.00. 
Number 34. Causes of geographical variations in the influenza epidemic of 1918 in the cities of the United States. A report of the Committee on Atmosphere and Man, of the National Research Council. Ellsworth Huntington, Chairman. July, 1923. Pages 35. Price $\$ 0.75$.

Number 35. Apparatus used in highway research projects in the United States. Results of census by Advisory Board on Highway Research, Division of Engineering, National Research Council, in cooperation with the Bureau of Public Roads, United States Department of Agriculture. C. A. Hogentogler. Angust, 1923. Pages 91. Price \$1.50.

Number 36. Catalogue of published bibliographies : in geology, I896-1920. Compiled by Edward B. Mathews. October, 1923. Pages 228. Price \$2.50.

\section{Volume ;}

Number 37. Thermal process time for canned food. Charles Olin Ball. October, 1923. Pages 76. Price $\$ 1.50$.

Number 38. Fellowships and scholarships for advanced work in science and technology. Compiled by Research Information Service, National Researcl Council. November, 1923. Pages 94. Price \$1.00.

Number 39. The quantum theory. Second edition. Revised and enlarged. E. P. Adams. November, 1923. Pages 109. Price \$1.50.

Number 40. Honors courses in American colleges and universities. Frank Aydelotte. January, 1924. Pages 57. Price $\$ 0.75$.

Number 41. Transactions of the American Geophysical Union, Fourth Annual Meeting, April, 1923, Washington, D. C. January, I924. Pages 150, Price $\$ 2.00$.

Number 42. Cooperative experiments upon the protein requirements for the growth of cattle. Report of Subcommittee on Animal Nutrition. E. B. Forbes, Chairman. February, 1924. Pages 44. Price \$0.75.

\section{Volume 8}

Number 43. Proceedings of the Third Annual Meeting of the Advisory Board on Highway Research, Division of Engineering, National Research Council. Editor by William Kendrick Hatt and E. R. Olbrich. January, 1923. Pages I61. Price $\$ 2.00$.

Orders, accompanied by remittance, should be addressed to

$$
\text { Publications OrFice. }
$$

NATIONAL RESEARCH COUNCIL,

WASHINGTON, D. C. 


\section{Reprint and Circular Series}

Number 1. Report of the Patent Committee of the National Research Council. Presented for the Committee by L. H. Baekeland, Acting Chairman. February, 1919. Pages 24. Price \$0.30.

Number 2. Report of the Psychology Committee of the National Research Council. Presented for the Committee by Robert M. Yerkes, Chairman. March, I9I9. Pages 51. Price \$o.6o. [Out of print.]

Number 3. Refractory materials as a field for research. By Edward W. Washburn. January, 1919. Pages 24. Price \$o.30.

Number 4. Industrial research. By Frank B. Jewett. 1918. Pages I6. Price $\$ 0.25$.

Number 5. Some problems of sidereal astronomy. By Henry Norris Russell. October, 1919. Pages 26. Price \$0.30.

Number 6. The development of research in the United States. By James Rowland Angell. November, 1919. Pages 19. Price \$0.25.

Number 7. The larger opportunities for research on the relations of solar and terrestrial radiation. By C. G. Abbot. February, 1920. Pages 15. Price \$0.20.

Number 8. Science and the industries. By John J. Carty. February, I920. Pages 16. Price $\$ 0.25$.

Number 9. A reading list on scientific and industrial research and the service of the chemist to industry. By Clarence Jay West. April, 1920. Pages 45. Price \$0.50.

Number 10. Report on the organization of the International Astronomical Union. Presented for the American Section, International Astronomical Union, by W. W. Camplell, Chairman, and Joel Stebbins, Secretary. June, I920. Pages 48. Price $\$ 0.50$.

Number 11. A survey of research problems in geophysics. Prepared by Chairmen of Sections of the American Geophysical Union. October, 1920. Pages 57. Price $\$ 0.60$.

Number 12. Doctorates conferred in the sciences in 1920 by American universities. Compiled by Callie Hull. November, 1920. Pages 9. Price \$o.20. IOut of print.]

Number 13. Research problems in colloid cliemistry. By Wilder D. Bancroft. January-April, 1921. Pages 54. Price \$0.50. [Out of print.]

Number 14. The relation of pure science to industrial research. By John J. Carty. October, 1916. Pages I6. Price \$0.20.

Number 15. Researches on modern brisant nitro explosives. By C. F. van Duin and B. C. Roeters van Lennep. Translated by Cliarles E. Munroe. February, 1920. Pages 35. Price $\$ 0.50$.

Number 16. The reserves of the Chemical Warfare Service. By Charles H. Herty. February, 1921. Pages 17. Price $\$ 0.25$.

Number 17. Geology and geography in the United States. By Edward B. Mathews and Homer P. Little. April, I92I. Pages 22. Price \$0.20. [Out of print.]

Number 18. Industrial benefits of research. By Charles L. Reese and A. J. Wadhams. February, 1921. Pages 14. Price $\$ 0.25$.

Number 19. The university and research. By Vernon Kellogg. June, I92r. Pages I0. Price $\$ 0.15$.

Number 20. Libraries in the District of Columbia. Compiled by W. I. Sivanton in coopperation with the Research Information Service of the National Research Council and Special Libraries. June, 1921. Pages 19. Price $\$ 0.25$.

Number 21. Scientific abstracting. By Gordon S. Fulcher. September, 1921. Pages 15. Price $\$ 0.20$. 
Number 22. The National Research Council. Its services for mining and metallurgy. By Alfred D. Flinn. October, 1921. Pages 7. Price \$0.20.

Number 23. American research chemicals. By Clarence J. West. September, I92I. Pages 28. Price $\$ 0.50$.

Number 24. Organomagnesium compounds in synthetic chemistry: a bibliography of the Grignard reaction 1900-192I. By Clarence J. West and Henry Gilman. January, 1922. Pages 103. Price \$1.50.

Number 25. A partial list of the publications of the National Research Council to January I, 1922. February, 1922. Pages 15. Price \$0.25.

Number 26. Doctorates conferred in the sciences by American universities in $192 \mathrm{I}$. Compiled by Callie Hull and Clarence J. West. March, 1922. Pages 20. Price $\$ 0.20$.

Number 2\%. List of manuscript bibliographies in geology and geography. Compiled by Homer P. Little. February, 1922. Pages 17. Price \$0.25.

Number 28. Investment in chemical education in the United States, I920-192I. By Clarence J. West and Callie Hull. March, 1922. Pages 3. Price \$0.15.

Number 29. Distribution of graduate fellowships and scholarships between the arts and sciences. Compiled by Callie Hull and Clarence J. West. April, I922. Pages 5. Price \$0.15.

Number 30. First report of the Committee on Contact Catalysis. By Wilder D. Bancroft, Chairman. In collaboration with the other members of the committec. April-July, 1922. Pages 43. Price \$0.50.

Number 31. The status of "clinical" psychology. By F. L. Wells. January, 1922. Pages I2. Price $\$ 0.20$.

Number 32. Moments and stresses in slabs. By H. M. Westergaard and W. A. Slater. April, 1922. Pages I24. Price \$1.00.

Number 33. Informational needs in science and technology. By Charles L. Reese. May, 1922. Pages 10. Price $\$ 0.20$.

Number 34. Indexing of scientific articles. By Gordon S. Fulcher. August, 1922. Pages i6. Price $\$ 0.20$.

Number 35. American research chemicals. First revision. By Clarence J. West. May, 1922. Pages 37. Price \$o.50. [Replaced by Number 44.]

Number 36. List of manuscript bibliographies in chemistry and clemical teclunology. By Clarence J. West and Callie Hull. December, 1922. Pages 17. Price $\$ 0.25$.

Number 3\%. Recent geographical work in Europe. By W. L. G. Joerg. July, 1922. Pages 54. Price $\$ 0.50$.

Number 38. The abstracting and indexing of biological literature. J. R. Schramm. November, 1922. Pages 14. Price $\$ 0.25$.

Nimber 39. A national focus of science and research. George Ellery Hale. November, 1922. Pages I6. Price $\$ 0.25$.

Number 40. The usefulness of analytic abstracts. Gordon S. Fulcher. December, 1922. Pages 6. Price \$0.I5.

Number 41. List of manuscript bibliographies in astronomy, matlematics, and physics. Clarence J. West and Callie Hull. March, I923. Pages I4. Price $\$ 0.25$.

Number 42. Doctorates conferred in the arts and the sciences by American universities, I92I-1922. Clarence J. West and Callie Hull. March, 1923. Pages I4. Price $\$ 0.25$.

Number 43. Functions of the Division of Geology and Geography of the National Research Council. Nevin M. Fenneman. December, 1922. Pages 7. Price \$0.20.

Number 44. Fine and research chemicals. Second revision. Clarence J. West. May, 1923. Pages 45. Price $\$ 0.50$. 
Number 45. List of manuscript bibliographies in the biological sciences. Clatence J. West and Callie Hull. June, 1923. Pages 5I. Price \$0.50.

Number 46. Problems in the field of animal nutrition. Sub-committee on Animal Nutrition. May, 1923. Pages 9. Price \$o.15.

Number 4\%. A statistical study of tuberculosis mortality in Colorado for the thirteen years 1908 to 1920. Henry Sewall. August, 1923. Pages 33. Price \$0.50.

Number 48. Psychological work of the National Research Council. Robert M. Yerkes. November, 1923. Pages 7. Price \$0.20.

Number 49. Statement of activities of the National Research Council for the year, July I, I922-June 30, I923. Vernon Kellogg. November, I923. Pages I6. Price \$0.25.

Number 50. Second report of the Committee on Contact Catalysis. Wilder D. Bancroft, Chairman. In collaboration with other members of the committee. December, 1923. Pages I4I. Price \$0.50.

Number 51. The higher agricultural education of the future. E. Marchill. AprilJune, 1923. Pages 6. Price \$0.20.

Orders, accompanied by remittance, should be addressed to

Publications OfFice

NATIONAL RESEARCH COUNCIL

Washington, D. C 



\section{DUE DATE}

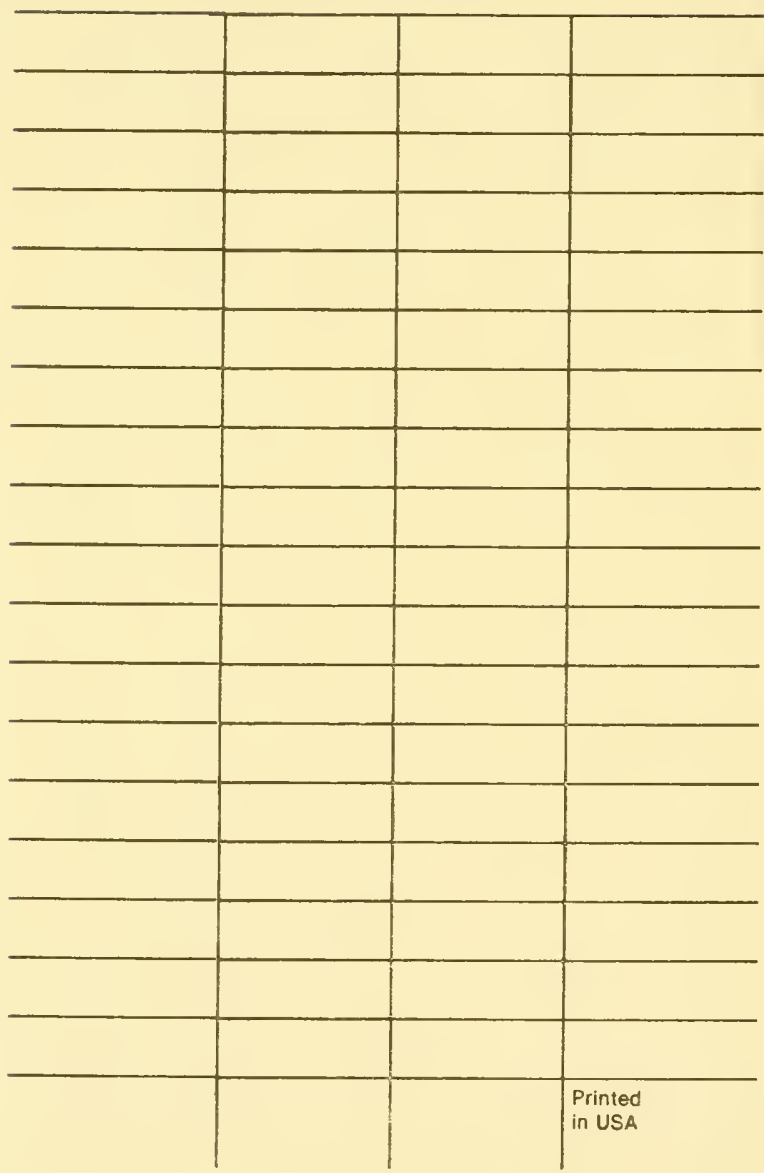



